Aus der Medizinischen Klinik und Poliklinik IV der Ludwig-Maximilians-Universität München

Direktor: Prof. Dr. med. Martin Reincke

In-vitro culture stress due to ambient $\mathrm{O}_{2}$ induces a senescent-like phenotype with abundant DNA repair activity

Dissertation zum Erwerb des Doktorgrades der Medizin an der Medizinischen Fakultät

der Ludwig-Maximilians-Universität München

vorgelegt von

LISA-MARLEN ROGMANN

aus Bochum

München 2016 
Mit Genehmigung der Medizinischen Fakultät der Universität München

Berichterstatter:

Mitberichterstatter:
Prof. Dr. med. Ralf Schmidmaier, MME Prof. Dr. med. Dr. rer. nat. Markus Kipp Prof. Dr. med. Claus Belka

Mitbetreuung durch: Dean E. Morbeck, Ph.D.

Dekan: Prof. Dr. med. dent. Reinhard Hickel

Tag der mündlichen Prüfung: $\quad$ 07.04.2016 
Teile dieser Arbeit wurden publiziert in:

A Meuter, LM Rogmann, BJ Winterhoff, T Tchkonia, JL Kirkland, DE Morbeck:

Markers of cellular senescence are elevated in murine blastocysts cultured in vitro: molecular consequences of culture in atmospheric oxygen Journal of assisted reproduction and genetics 31 (10), 1259-1267 (2014)

L Rogmann, B Winterhoff, J Fredrickson, T Trejo, A Meuter, DE Morbeck: In vitro culture stress due to ambient 02 induces a senescent-like phenotype with abundant DNA repair activity

Fertility and Sterility 98 (3), S287 (2012)

Teile dieser Arbeit wurden auf folgenden Kongressen präsentiert:

- 60. Kongress der Deutschen Gesellschaft für Gynäkologie und Geburtshilfe, München, 8. -11. Oktober 2014

- Mayo Clinic Young Investigator Research Symposium; 31. März 2012, Rochester, MN

- 68th Annual Meeting of the ASRM; 20. Oktober 2012, San Diego

Diese Arbeit wurde ausgezeichnet mit:

Distinguished Poster Award for Medical Student;

Young Investigator Research Symposium, Mayo Clinic (Rochester, MN);

31. März 2012 


\section{Table of contents}

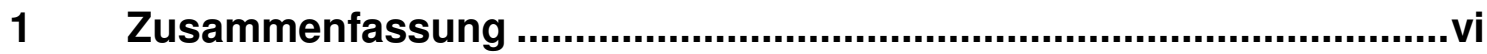

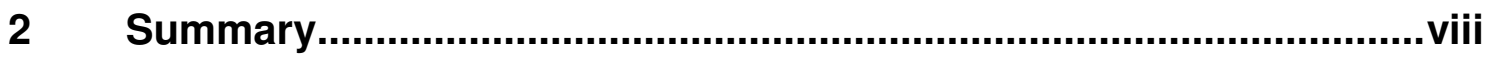

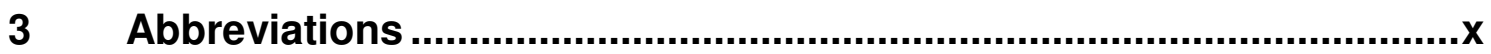

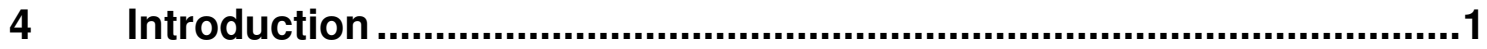

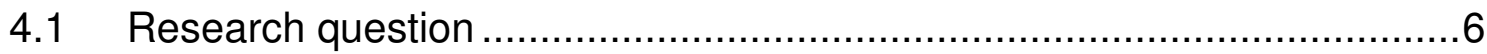

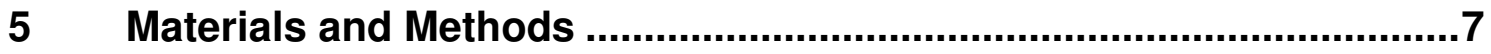

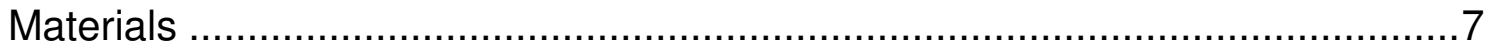

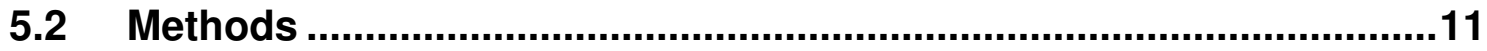

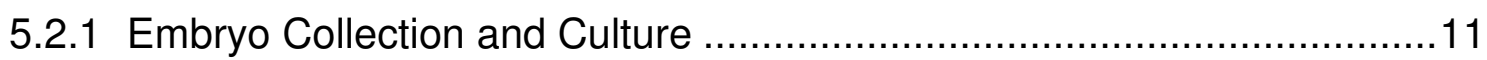

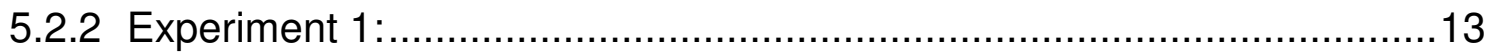

5.2.2.1 Senescence-associated B-galactosidase Assay ..............................13

5.2.2.2 Gamma -H2A.X Immunofluorescence Staining ..............................16

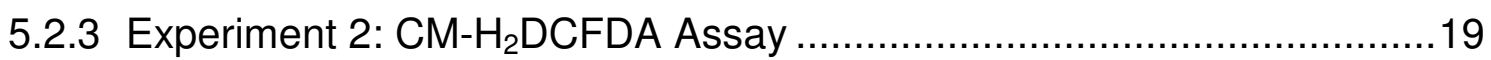

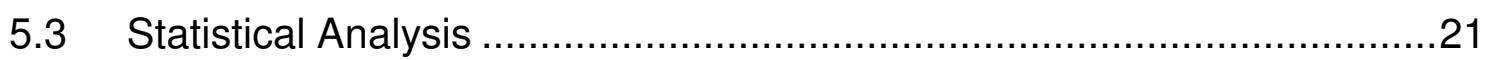

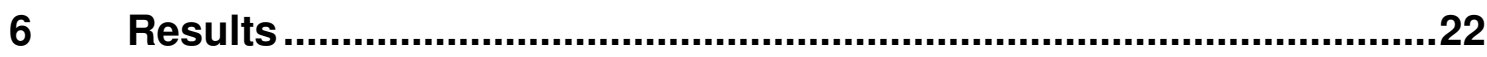

6.1 Culture in $5 \%$ oxygen reduced markers of cellular senescence to levels similar to those seen in-vivo..................................................22

6.1.1 $5 \% \mathrm{O}_{2}$ environment revealed lowest Senescence-associated B-

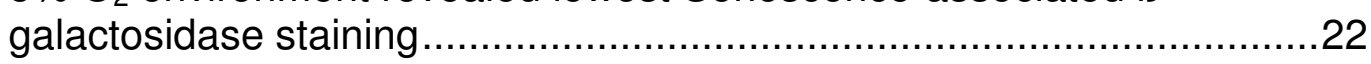

6.1.2 The lowest amount of $\mathrm{y}-\mathrm{H} 2 \mathrm{AX}$ positive stained embryos was shown in reduced $(5 \%)$ oxygen concentrations with protein supplementation ...25

$\rightarrow$ In addition $20 \%$ oxygen without protein conditions seems to reduce cell

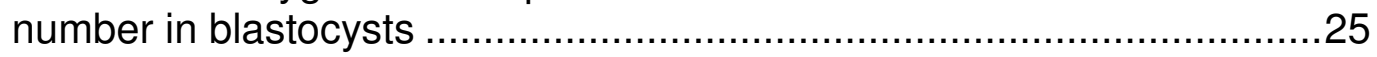

6.2 Intracellular ROS levels in live blastocysts were reduced by $5 \% \mathrm{O}_{2}$ culture

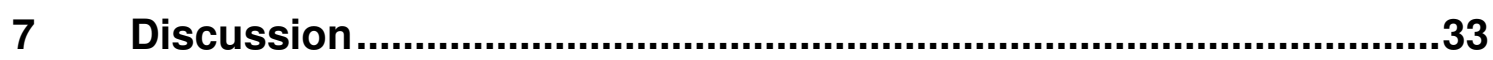

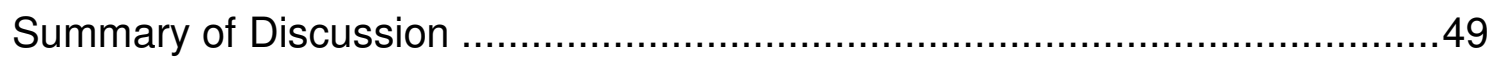

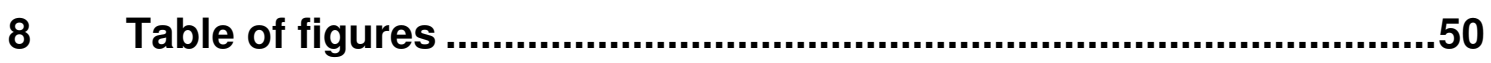

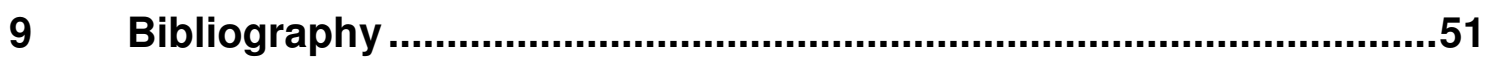

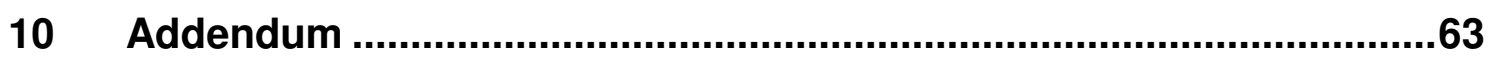

10.1 Publication: Markers of cellular senescence are elevated in murine blastocysts cultured in-vitro: molecular consequences of culturing in atmospheric oxygen 
10.2 Abstract: In-vitro culture stress due to ambient $\mathrm{O}_{2}$ induces a senescent-like phenotype with abundant DNA repair activity.... .72

10.3 Mayo Clinic Young Investigator Research Award .73

11 Declaration of academic honesty .74

12 Acknowledgements 75 


\section{Zusammenfassung}

EINLEITUNG: Bis zum heutigen Zeitpunkt sind schätzungsweise mehr als fünf Millionen Kinder durch assistierte Reproduktion (künstliche Befruchtung) auf die Welt gebracht worden. Seit 1997 ist die Zahl der durchgeführten assistierten Reproduktionszyklen (ART-cycles) jedes Jahr stetig gestiegen. Allerdings haben sich Schwangerschafts- und Lebendgeburtenraten nicht wesentlich verändert. Trotz der enormen Kosten ist das Ergebnis immer noch unzureichend, mit einer Erfolgsrate von nur etwa 30\% bei Frauen im Alter von 35 Jahren. Embryokulturbedingungen scheinen das Ergebnis der In-vitroFertilisation (IVF) nachteilig zu beeinträchtigen. Im Gegensatz zu den in-vivo Bedingungen verfügen die Kulturmedien nicht über die optimale Zusammensetzung der Faktoren, wie sie in den Flüssigkeiten im Reproduktionstrakt vorliegen. Zudem wird die Embryokultivierung häufig unter nicht physiologischen Umgebungssauerstoff-Konzentrationen durchgeführt. Dies führt zu einer hohen Frequenz an Fehlentwicklungsraten bei den in-vitro erzeugten Embryonen.

Zellalterung wird durch Stressstimuli getriggert und durch permanenten Zellzyklusarrest definiert. Eine vorherige Studie ergab erhöhte Marker für zelluläre Seneszenz in in-vitro gezüchteten Blastozysten im Vergleich zu in-vivo entwickelten. Dies zeigt, dass ein der Seneszenz ähnlicher Zustand durch oxidativen Stress und suboptimale Kulturbedingungen induziert werden kann. Jedoch war weiterhin fraglich, ob diese Effekte durch optimierte Embryokulturbedingungen beeinflusst werden können und ob atmosphärische $\mathrm{O}_{2}$-Bedingungen zur Bildung von reaktiven Sauerstoffradikalen (ROS) führen.

Das Ziel dieser Arbeit war zu untersuchen, ob optimierte Kulturbedingungen einen Einfluss auf die Expression der Seneszenz-Marker in murinen Blastozysten haben und ob Sauerstoffradikale in lebendigen Blastozysten nachweisbar sind.

MATERIAL UND METHODEN: Einzellige Maus-Embryonen wurden aus superovulierten FVB Mäusen gewonnen und in vier verschiedenen Versuchsgruppen 
( $5 \% / 20 \% \mathrm{O}_{2}$ Level +/- Proteinzusatz zum Kulturmedium) in-vitro bis zum Blastozystenstadium kultiviert. Die Blastozysten wurden fixiert und für Seneszenz-assoziierte- $\beta$-Galactosidase (SA- $\beta$-Gal) und phosphorylierte H2A.X (y-H2A.X) (repräsentative Marker der zellulären Seneszenz) gefärbt. Der Umfang des oxidativen Stresses wurde in lebendigen Blastozysten mit dem ROS Detektor CM- $\mathrm{H}_{2}$ DCFDA erfasst.

ERGEBNISSE: Unter reduzierten $\mathrm{O}_{2}$ Bedingungen (5\%) wurde im Vergleich zu Umgebungssauerstoffbedingungen (20\%) eine signifikante Abnahme der Expression der untersuchten Seneszenz-Marker (SA- $\beta$-gal/ y-H2A.X) sowie ROS Werte (via CM- $\mathrm{H}_{2}$ DCFDA gemessen) festgestellt. Die Zugabe von Protein in das Kulturmedium reduzierte die untersuchten Marken zusätzlich.

SCHLUSSFOLGERUNG: Die Ergebnisse zeigen, dass in reduziertem Sauerstoffgehalt kultivierte Embryonen eine verminderte Expression der zellulären Seneszenz-Marker aufzeigen. Dies ist potentiell auf eine erniedrigte Bildung von reaktiven Sauerstoffradikalen zurückzuführen. Die Zugabe von Protein scheint eine zusätzliche Wirkung als anti-oxidativer Radikalfänger zu haben. Die Kultivierung von Blastozysten in $5 \% \mathrm{O}_{2}$ mit Proteinzusatz reduzierte die gemessenen Marker auf Werte ähnlich derer gemessen in in-vivo Embryonen. Die Ergebnisse liefern weitere Beweise für die möglichen negativen Auswirkungen der Embryonenzucht bei atmosphärischen Sauerstoffkonzentrationen. Zusätzliche Untersuchungen von DNA-Schäden, dem zellulärem Seneszenz-Signalweg in Embryonen, der Rolle von oxidativem Stress und anderen Embryokulturbedingungen sind erforderlich, um eine genauere Kenntnis über das Zusammenspiel oben genannter Faktoren in der Embryokultivierung zu erhalten. 


\section{Summary}

INTRODUCTION: To the present it is estimated that more than five million children were born through assisted reproduction. Since 1997, the number of assisted reproductive technology (ART) cycles performed each year increased steadily. However, pregnancy and live birth rates did not change considerably. In spite of its tremendous cost, the outcome is still insufficient, with a success rate of only approximately $30 \%$ for women under the age of 35 . Embryo culture conditions seem to affect the outcome of in-vitro fertilization (IVF) adversely. Contrary to the in-vivo ambience, culture media lack the optimal composition of the factors present in the reproductive tract fluid and embryo culture frequently occurs under non-physiological ambient $\mathrm{O}_{2}$ concentrations, leading to a high frequency of developmental failure in the in-vitro produced embryos. Cellular senescence is defined by stable cell cycle arrest that is triggered by stress stimuli. A prior study showed that markers of cellular senescence were elevated in in-vitro derived blastocysts compared to in-vivo ones. Indicating that a senescence-like state may be induced through oxidative stress and suboptimal culture conditions. But it was still to be determined whether these effects can be influenced by optimized embryo culture conditions and if ambient $\mathrm{O}_{2}$ conditions lead to the formation of reactive oxygen species (ROS).

In this study the aim was to investigate if optimized culture conditions have an influence on the expression of cellular senescence markers in murine blastocysts and if amounts of radical oxygen species (ROS) are detectable in live blastocysts.

MATERIALS AND METHODS: Single-cell mouse embryos were collected from super ovulated FVB mice and cultured in-vitro to the blastocyst stage in four different experimental groups $\left(5 \% / 20 \% \mathrm{O}_{2}\right.$ levels $+/$ - protein addition to the media). Blastocysts were fixed and stained for Senescence-associated- $\beta$ galactosidase (SA- $\beta$-gal) and phosphorylated H2A.X (y -H2A.X) (as representative markers of cellular senescence). The level of oxidative stress in live blastocysts was detected using the ROS detector: $\mathrm{CM}-\mathrm{H}_{2} \mathrm{DCFDA}$. 
RESULTS: In reduced $\mathrm{O}_{2}$ conditions (5\%) in comparison to ambient $\mathrm{O}_{2}(20 \%)$, a significant decrease in the expression of the studied senescence markers (SA$\beta-g a l / y-H 2 . A . X)$ as well as ROS values (measured via CM- $\mathrm{H}_{2}$ DCFDA) was detected. The addition of protein to the culture medium further decreased measured markers.

CONCLUSION: Results indicate that decreased $\mathrm{O}_{2}$ during embryo culture minimizes the expression of markers of cellular senescence, maybe due to the reduction of ROS formation. Protein seems to aid as additional antioxidant scavenger. Culture of $5 \% \mathrm{O}_{2}$ with protein reduced markers to levels similar to those seen in in-vivo embryos. Results provide further evidence for potential adverse effects of culturing embryos at ambient $\mathrm{O}_{2}$ concentrations. Additional studies of DNA damage, the cellular senescence pathway in embryos, the role of oxidative stress and other embryo culture conditions are demandable to further investigate the impact of above-mentioned factors on blastocysts in culture. 


\section{Abbreviations}

AR

ART

BSA

CASP3/ 8/ 9

CF-1 mice

CM- $\mathrm{H}_{2}$ DCFDA

$\mathrm{CO}_{2}$

DAPI

DMSO

DNA

DPBS

e.g.

FAS/FASLG

FVB mice

GLB1

GPX

HCG

HEPES

HSA

HTF

H2A.X

i.a.
- Assisted Reproduction

- Assisted Reproductive Technologies

- Bovine serum albumin

- Caspase3/ 8/ 9

- Inbred mouse colony (1); from Carworth Farms

- 5-(and-6)-chloromethyl-2',7'-dichlorodihydrofluorescein diacetate

- Carbon dioxide

- 4'-6-Diamidino-2-phenylindole

- Dimethyl sulfoxide

- Deoxyribonucleic acid

- Dulbecco's phosphate buffered saline

- exempli gratia

- FAS ligand (type-II transmembrane protein that belongs to the tumor necrosis factor family)

- Inbred mouse colony for the Fvb1 gene (in-house)

- Galactosidase, beta-1

- Glutathione peroxidase

- Human chorionic gonadotropin

- 4-(2-hydroxyethyl)-1-piperazineethanesulfonic acid

- Human serum albumin

- Human tubal fluid

- Histone of H2A histone family; member: X

- inter alia 


\begin{tabular}{|c|c|}
\hline IACUC & - Institutional Animal Care and Use Committee \\
\hline ICM & - Inner cell mass \\
\hline ICSI & - Intracytoplasmic Sperm Injection \\
\hline IU & - International unit \\
\hline IVF & - In-Vitro Fertilization \\
\hline KSOM-AA & - Potassium simplex optimization medium with amino acids \\
\hline LSM780 & - Laser scanning microscope (Zeiss; model: 780) \\
\hline M & - Molar \\
\hline $\mathrm{ml}$ & - Milliliter \\
\hline $\mathrm{mM}$ & - Milimolar \\
\hline$n$ & - Particle number $(N) ; n=1 \equiv 1$ embryo \\
\hline $\mathrm{nm}$ & - Nanometer \\
\hline $\mathrm{N}_{2}$ & - Nitrogen \\
\hline $\mathrm{O}_{2}$ & - Oxygen \\
\hline PBS & - Phosphate buffered saline \\
\hline PMS & - Pregnant Mare's Serum \\
\hline Polysorbate20 & - Polyoxyethylene (20) sorbitan monolaurate (Tween20) \\
\hline PVA & - Polyvinyl alcohol \\
\hline ROS & - Reactive Oxygen Species \\
\hline$S A-\beta-g a l$ & - Senescence associated beta-galactosidase \\
\hline Ser-139 & - Serine 139 \\
\hline SSS & - Serum Substitute Supplement \\
\hline TG & - Treatment group \\
\hline TX100 & $\begin{array}{l}\text { - Polyethylene glycol p-(1,1,3,3-tetramethylbutyl)- } \\
\text { phenylether }\end{array}$ \\
\hline UV- light & - Ultraviolet light \\
\hline
\end{tabular}




$\begin{array}{ll}\text { v/v } & \text { - Volume-in-volume solution } \\ \text { X-gal } & \text { - 5-bromo-4-chloro-3-indoyl } \beta \text {-D-galactopyranoside } \\ \text { Z-stack } & \text { - 3-dimensional imaging }(x-y-z) \\ \text { Y-H2A.X } & \text { - Phosphorylated H2A.X } \\ \mu \mathrm{l} & \text { - Microliter } \\ \mu \mathrm{M} & \text { - Micromolar } \\ \% & \text { - Percent }\end{array}$




\section{Introduction}

In this day and age there is a widespread use of assisted reproductive technologies (ART). The use of ART increased steadily and got simplified after the first baby, Louise Brown, was born in England in 1978 after being conceived using in-vitro fertilisation. In Germany, the law on the protection of embryos (Embryo Protection Act), enacted on $13^{\text {th }}$ of December in 1990, governs the legal framework for the implementation of in-vitro fertilization (Diedrich, 2007). A couple is called sterile if is has unprotected intercourse for one year without resulting in a pregnancy. Nowadays already one out of six couples experiences problems with fertility and takes the plunge to direct towards ART to procure help receiving a baby on their own (Farquhar, Jr, Brown et al., 2013). One of the reasons is that women in these days tend to decide to have a baby of their own at a more advanced age, which also increases the risk of aberration and abortion. Reproductive medicine gained in importance and by now many couples experienced the unique sensation of giving birth to a child with the help of ART. To the present it is estimated that since 1997 more than five million children were born worldwide through assisted reproduction (Kupka et al., 2014). A cross sectional survey showed that in 2006 over 1.0 million ART cycles were performed worldwide, which resulted in an estimated number of $>250,000$ babies born (Mansour et al., 2014).

In-vitro fertilization describes a process where one or more oocytes are retrieved from stimulated ovaries, which can be achieved through transvaginal follicular puncture with sonographic guidance after hormone and sonographic control (Schorge et al., 2008). In a sterile laboratory environment, oocytes are coupled with spermatozoa in-vitro in a special media. Due to spontaneous insemination, "normal" selection of viable and rapid spermatozoa occurs and after successful fertilization, viable embryos are implanted into the uterus transcervically with sonographic guidance. Despite its increased utilisation and importance, being sterile and the consecutive use of reproductive medicine is still complicated in many respects, especially for the couples affected. The problematic toopics include: costs, psychological aspects, technological improvement, socio-political acceptability as well as political and legal 
dimensions. In spite of its tremendous cost, the outcome is still insufficient, with a success rate of only approximately $30 \%$ for women under the age of 35 (Ferraretti et al., 2013; Kupka et.al, 2014). Chances of success decrease and rates of abortion increase after the 35th year of age and the cumulative success rate for women over the age of 40 declines to just $5 \%$ (Jansen, 2003). In general a pregnancy results in $20-40 \%$ of the cases (early abortion rate approximately $80 \%$, multiple pregnancy rate (twins) about 20\%) and is highly dependent on the mother's age at the time of egg retrieval, national legislation as well as on modern IVF technologies (Kupka et al., 2014; Mansour et al., 2014). Since 1997, the number of ART cycles performed each year increased steadily. The number of embryos transferred shifted from several to single embryo transfer, resulting in decreased multiple births rates. However, pregnancy and live birth rates did not change considerably (Nygren \& Andersen, 2001; Mansour et al., 2014) .

In defiance of already above mentioned fallouts on IVF outcomes, other factors which affect the outcome of IVF adversely come into addition. Most of all, embryo culture conditions themselves, particularly used media and incubator oxygen tension (Kind et al., 2005; Nelissen et al., 2012). Embryo culture, as an important part of the IVF procedure, deals with the handling of highly vulnerable cells at a critical state of development. It involves extracting oocytes and spermatozoa out of their natural surroundings and exposes them to an ambience which varies in many respects from their physiological milieu. During in-vitro development, embryos are exposed to a variety of exogenous and endogenous factors, including ions, buffers, growth factors, amino acids, energy substrates and the gas atmosphere (D Rieger et al. 1992), which can cause developmental arrest or degeneration, leading to a blastocyst rate less than 50\% (Plante, Betteridge, \& King, 1989; Thomas et al., 2010). After embryo transfer, many blastocysts are unable to sustain viability and do not result in a pregnancy (Crosier et al., 2001). Contrary to the in-vivo ambience, culture media lack the optimal composition of the factors present in reproductive tract fluid and embryo culture frequently occurs under non-physiological atmospheric oxygen concentrations (a J. Harvey, 2007), leading to a high frequency of developmental failure in the in-vitro produced embryos. Reasons remain unclear but developmental arrest has been proposed as a protective 
mechanism for preventing further development of abnormal, poor quality embryos (L. A. Favetta et al., 2007).

When actively growing cells accumulate a critical level of cellular damage, proliferation ceases and cells undergo programmed death (apoptosis or autophagy) or permanent cell cycle arrest (senescence). Apoptosis represents an end point of cell fate: the culmination of cellular damage and the signature of a cell that is unable to overcome intrinsic defects or extrinsic insults. Cellular senescence is another programmed cell response to in-vitro stress that similar to apoptosis, represents the culmination of damage and corresponding cellular responses (Meuter, Rogmann et al., 2014). Due to a lack of apoptotic signs (chromatin condensation, nuclear fragmentation, apoptotic bodies) during early cleavage stages (Betts \& King, 2001b) as well as the absence or very low abundance of transcripts for CASP3, CASP9, CASP8 and FAS/FASLG (Leidenfrost et al., 2011), it is questionable whether classical caspase-mediated apoptosis is the major cause of cell death in early embryo development. Assumingly embryos could be arrested in a senescent-like stage (Betts \& Madan, 2008). Cellular senescence, first of all described by L. Hayflick in 1961, represents a phenomenon where cells enter a permanent cell cycle arrest state (Hayflick \& Moorhead, 1961; L. A. Favetta et al., 2004;) while still being metabolically active (Tarin, 1996). This is in contrast to quiescent and terminally differentiated cells (Kurz et al., 2000) and senescent cells also seem to exhibit high levels of intracellular ROS (L. A. Favetta et al., 2007).

The Senescence-associated-beta galactosidase assay is very useful for testing whether different conditions or compounds can induce or inhibit the appearance of senescent cells (Dimri et al., 1995; Debacq-Chainiaux et al., 2009). Classic acid beta-galactosidase is an enzyme present in the lysosomes of all eukaryotic cells and functions as a cellular waste component processor (Ishii et al., 1995). It is distinguishable from senescence-associated beta-galactosidase by its pKa due to augmented lysosomal mass accompanied by increased enzyme activity. Therefore the assay can be used to study the emergence of senescent cells after exposure to different types of stressors (Debacq-Chainiaux et al., 2005; Dumont et al., 2000; Frippiat et al., 2001). 
It is extensively studied that reactive oxygen species are implicated in the induction of cellular senescence (Passos, Von Zglinicki, \& Kirkwood, 2007). Under conditions of elevated oxidative stress, e.g. in culture, cellular senescence can occur prematurely (Dumont et al., 2000; von Zglinicki, 2000; Frippiat et al., 2001; Passos, Saretzki, \& von Zglinicki, 2007) and can also be activated by the disruption of the telomere structure ( $\mathrm{Li}, 2003$; Stewart, Wang, Bignell, Taylor, \& Elledge, 2003). This can be measured by gamma-H2A.X fluorescence, a marker of DNA damage to the telomeres, indicating telomere dysfunction-induced foci (M. B. Harvey et al., 1995; Herbig et al., 2004; Fragkos et al., 2009) or DNA damage-induced cellular senescence (Passos, Saretzki, et al., 2007).

It has previously been shown that bovine embryos (at the 2 to 4 cell stage) cultured in $20 \%$ oxygen conditions reveal higher frequencies of permanent embryo arrest and significantly elevated levels of intracellular ROS compared with embryos cultured in 5\% oxygen atmospheres (L. a Favetta et al., 2007). This evidence suggests a relation between near-atmospheric oxygen concentrations, intracellular ROS production and embryo arrest, although this is not yet shown for embryos at the blastocyst stage, being the most important developmental stage prior to implementation in the uterus cavity. Hence, oxygen tension is a substantial factor during embryo culture. Although IVF needs to take place at a certain oxygen concentration, it is well known that suboptimal culture conditions, where non-physiological $\mathrm{O}_{2}$ concentration appertains to, can cause a high frequency of developmental failure (Betts \& King, 2001a; L. A. Favetta et al., 2004). Being part of the natural cell metabolism and important for intracellular signalling and cellular functions, oxygen radicals are existential in certain quantities, but can result into oxidative stress under pathological conditions and concentrations (Nasr-Esfahani \& Johnson, 1991). An imbalance between over-abundant oxygen supply and metabolic needs may procure meiotic arrest and/ or apoptotic cell death induced by DNA breaks and damage through caspase 3 activation (Tatemoto, Muto, Sunagawa, Shinjo, \& Nakada, 2004). During embryo culture this "imbalance" could be generated through ambient oxygen levels, which are not even close to physiological in-vivo conditions, but still commonly used (Bontekoe et al., 2012). 
Methods to measure ROS in-vivo especially live imaging become more and more important and notable progress has been made in probe developing during the past years. The fluorogenic marker $\mathrm{CM}-\mathrm{H}_{2} \mathrm{DCFDA}$ for reactive oxygen species in live cells can be used as an indicator for oxidative stress to cells in in-vitro culture (Badham et al., 2010; Kawamura et al., 2010). It passively diffuses into cells and accumulates mostly in the cytosol where intracellular oxidation yields a fluorescent adduct that can be measured using fluorescence microscopy (Halliwell \& Whiteman, 2004).

Nowadays single embryo transfer became more important, in order to avoid the additional risk of multiple pregnancies. Embryos are cultured until reaching the blastocyst stage (regularly under $20 \%$ oxygen conditions) and implanted in the uterus after morphological selection. Resulting implantation, pregnancy as well as live birth rates are not satisfying, considering the cost, effort and psychological impact on affected couples. Therefore the need of optimal-quality embryos is high but methods to determine embryo health are not adequately and early embryonic markers to determine optimal embryo development are yet to be identified. Prior to this study, the same working group around D.E. Morbeck compared senescence markers (SA-beta-galactosidase, y-H2A.X and p21, p16, IL6) respectively in in-vivo and in-vitro derived blastocysts (culture conditions: $20 \%$ oxygen without protein supplement) and showed that markers of cellular senescence were elevated in in-vitro derived blastocysts. Significant results were obtained for the SA-beta-galactosidase, y-H2A.X and p21 markers, supporting the hypothesis that markers of cellular senescence are expressed in murine blastocysts cultured in-vitro, indicating that a senescence-like state may be induced through oxidative stress and suboptimal culture conditions (Meuter, Rogmann et al., 2014). However, it was still to be determined whether these effects can be influenced by optimized embryo culture conditions and if atmospheric oxygen conditions lead to the formation of reactive oxygen species, a possible stressor during embryo development prior to implantation. 


\subsection{Research question}

Do optimized culture conditions have an influence on the expression of cellular senescence markers in murine blastocysts?

Based upon the published knowledge two conditions were tested:

1. In-vitro culture in atmospheric and reduced oxygen conditions

2. Medium with or without protein supplementation (as a source of antioxidant)

Cellular senescence was determined by expression of SA-beta galactosidase and $y-H 2 A . X$ (as representative markers of cellular senescence).

Secondly we aimed to investigate if amounts of radical oxygen species (ROS) are detectable in live blastocysts that were cultivated in either atmospheric or reduced oxygen culture settings with/ without protein supplement.

\section{Design}

\section{Experiment one:}

Effects of oxygen and protein on markers of cellular senescence were studied using a $2 \times 2$ factorial design, with 2 levels of oxygen ( $5 \%$ vs $20 \%$ ), with or without $10 \% \mathrm{v} / \mathrm{v}$ protein (serum substitute supplement (SSS)).

After $96 \mathrm{~h}$ of culture, blastocysts were obtained from a minimum of 3 replicates, with at least 30 blastocysts obtained from one out of the four different culture settings for both SA- $\beta$-galactosidase and $\gamma$ - H2A.X assays.

\section{Experiment two:}

Effects of oxygen and protein on ROS formation in live blastocysts derived from two different culture systems: $5 \%$ oxygen with $10 \% \mathrm{v} / \mathrm{v}$ protein supplement and $20 \%$ oxygen without protein supplement.

After $96 \mathrm{~h}$ of culture, blastocysts were obtained from a minimum of 3 replicates, with at least 30 blastocysts obtained from both culture settings for the $\mathrm{CM}$ $\mathrm{H}_{2}$ DCFDA assay. 


\section{Materials and Methods}

\section{Materials}

\begin{tabular}{|c|c|c|}
\hline Culture medium/ additives & $\begin{array}{l}\text { Abbr./ } \\
\text { Quantity/ } \\
\text { Type }\end{array}$ & Manufacturer \\
\hline $\begin{array}{l}\text { Dulbecco's phosphate buffered } \\
\text { saline }\end{array}$ & DPBS & Life technologies, TM, USA \\
\hline Global medium & & $\begin{array}{l}\text { IVFonline; Guelph, Ontario, } \\
\text { Canada }\end{array}$ \\
\hline Human chorionic gonadotropin & $\mathrm{HCG}$ & $\begin{array}{l}\text { APP Pharmaceuticals, } \\
\text { Schaumburg, IL, USA }\end{array}$ \\
\hline Human Serum Albumin & HSA & $\begin{array}{l}\text { Cooper Surgical, Trumball, } \\
\text { CT, USA }\end{array}$ \\
\hline Human tubal fluid medium & HTF & $\begin{array}{l}\text { IVFonline; Guelph, Ontario, } \\
\text { Canada }\end{array}$ \\
\hline Mineral Oil, Light & O121-1 & $\begin{array}{l}\text { Fisher Scientific, Fair Lawn, } \\
\text { NJ, USA }\end{array}$ \\
\hline Phosphate-buffered saline & PBS & $\begin{array}{l}\text { Invitrogen, Grand Island, NY, } \\
\text { USA }\end{array}$ \\
\hline Polyvinyl alcohol & PVA & $\begin{array}{l}\text { Sigma Aldrich, St. Louis, } \\
\text { MO, USA }\end{array}$ \\
\hline Pregnant mare's serum & PMS & NHPP Torrance, CA, USA \\
\hline Serum Substitute Supplement & SSS & Irvine Scientific, CA, USA \\
\hline $\begin{array}{l}\text { 4-(2-hydroxyethyl)-1- } \\
\text { piperazineethanesulfonic acid }\end{array}$ & HEPES & $\begin{array}{l}\text { InVitro Care ; Frederick, MD, } \\
\text { USA }\end{array}$ \\
\hline Embryo handling & & Manufacturer \\
\hline Micropipetter: the STRIPPER® & & Origio, New Jersey, USA \\
\hline Stripper tips & $125 \mu \mathrm{m}$ & Origio, New Jersey, USA \\
\hline \multicolumn{3}{|l|}{ Incubator } \\
\hline $\mathrm{CO}_{2}$ free incubator & & \\
\hline
\end{tabular}




\begin{tabular}{|c|c|c|}
\hline $\mathrm{CO}_{2}$ Water Incubator & 3110 & Thermo Forma Scientific \\
\hline \multicolumn{3}{|l|}{ Microscope } \\
\hline Laser scanning microscope & LSM780 & Carl Zeiss, Jena, Germany \\
\hline Light microscope & & Nikon, Melville, NY \\
\hline \multicolumn{3}{|l|}{ Labware } \\
\hline Aerosol Resistant Tips & ART $\AA$ & $\begin{array}{l}\text { Taylor Scientific, St. Louis, } \\
\text { Missouri, USA }\end{array}$ \\
\hline Four-well dish & Nunc $^{T M}$ & $\begin{array}{l}\text { Thermo Scientific, } \\
\text { Rochester, NY, USA }\end{array}$ \\
\hline Microtube & $1,5 \mathrm{ml}$ & Sarstedt, USA \\
\hline Orbital shaker & VSOS-4P & $\begin{array}{l}\text { Pro Scientific; Oxford, CT, } \\
\text { USA }\end{array}$ \\
\hline Petri dish & 1006 & $\begin{array}{l}\text { Falcon } \AA^{\circledR} \text {, Becton Dickinson } \\
\text { Labware; Franklin, NJ, USA }\end{array}$ \\
\hline Polypropylene round-bottom tube & $\begin{array}{l}5 \mathrm{ml} \\
10 \mathrm{ml} \\
20 \mathrm{ml} \\
50 \mathrm{ml}\end{array}$ & $\begin{array}{l}\text { Falcon }{ }^{\circledR} \text {, Becton Dickinson } \\
\text { Labware; Franklin, NJ, USA }\end{array}$ \\
\hline $\begin{array}{l}\text { Precision micro liquid transfer } \\
\text { device }\end{array}$ & $\begin{array}{l}\text { Pipet- } \\
\text { Aid® }\end{array}$ & $\begin{array}{l}\text { Drummond Scientific, } \\
\text { Broomall, PA, USA }\end{array}$ \\
\hline Serological glass pipet & $5 \mathrm{ml}$ & $\begin{array}{l}\text { Falcon } \AA \text {, Becton Dickinson } \\
\text { Labware; Franklin, NJ, USA }\end{array}$ \\
\hline Stirrer plate & & $\begin{array}{l}\text { USA Scietific, Ocala, FL, } \\
\text { USA }\end{array}$ \\
\hline Tissue culture dish & 3001 & $\begin{array}{l}\text { Falcon }{ }^{\circledR} \text {, Becton Dickinson } \\
\text { Labware; Franklin, NJ, USA }\end{array}$ \\
\hline \multicolumn{3}{|l|}{ Chemicals } \\
\hline Bovine Serum Albumin powder & $\begin{array}{l}\text { BSA } \\
\text { powder }\end{array}$ & $\begin{array}{l}\text { MP Biomedicals, LLC; } \\
\text { Solon, Ohio, USA }\end{array}$ \\
\hline Citric acid & $\mathrm{pH} 6 ; \mathrm{pH} 4$ & $\begin{array}{l}\text { Sigma Aldrich, St. Louis, } \\
\text { MO, USA }\end{array}$ \\
\hline Dimethylsulfoxide & DMSO & $\begin{array}{l}\text { Sigma Chemical, St. Luis, } \\
\text { MO, USA }\end{array}$ \\
\hline Glutaraldehyde & & Sigma Aldrich, St. Louis, \\
\hline
\end{tabular}




\begin{tabular}{|c|c|c|}
\hline & & MO, USA \\
\hline Magnesium chloride & & $\begin{array}{l}\text { Boston BioProducts, } \\
\text { Ashland, MA, USA }\end{array}$ \\
\hline Molecular water & & $\begin{array}{l}\text { Cellgro, Mediatech, Inc. } \\
\text { Manassas, VA, USA }\end{array}$ \\
\hline Paraformaldehyde & $10 \mathrm{ml}$ vial & $\begin{array}{l}\text { Electron Microscopy } \\
\text { Sciences, Hatfield, PA, USA }\end{array}$ \\
\hline $\begin{array}{l}\text { Polyoxyethylene (20) sorbitan } \\
\text { monolaurate }\end{array}$ & Tween20 & $\begin{array}{l}\text { Sigma-Aldrich, St. Louis, } \\
\text { MO, USA }\end{array}$ \\
\hline Potassium ferracyanide & & $\begin{array}{l}\text { MP Biomedicals, Solon, OH, } \\
\text { USA }\end{array}$ \\
\hline Potassium ferrocyanide & & $\begin{array}{l}\text { Sigma Aldrich, St. Louis, } \\
\text { MO, USA }\end{array}$ \\
\hline Sodium chloride & & $\begin{array}{l}\text { Boston BioProducts, } \\
\text { Worcester, MA, USA }\end{array}$ \\
\hline Triton-X-100 & TX100 & $\begin{array}{l}\text { Thermo Fisher Scientific, } \\
\text { Rockford, IL, USA }\end{array}$ \\
\hline Vectashield mounting medium & & $\begin{array}{l}\text { Vector Laboratories, } \\
\text { Burlingame, CA, USA }\end{array}$ \\
\hline $\begin{array}{l}\text { 3\% 4'-6-Diamidino-2-phenylindole } \\
\text { (DAPI) in Vectashield mounting } \\
\text { medium }\end{array}$ & stock & $\begin{array}{l}\text { IVF laboratory, Mayo Clinic, } \\
\text { Rochester, MN, USA }\end{array}$ \\
\hline 4'-6-Diamidino-2-phenylindole & DAPI & $\begin{array}{l}\text { Abbott Molecular, Chicago, } \\
\text { IL, USA }\end{array}$ \\
\hline \multicolumn{3}{|l|}{ Laboratory Animals } \\
\hline $\begin{array}{l}\text { Friend Virus B; Inbred mouse } \\
\text { colony; female mice }\end{array}$ & FVB & $\begin{array}{l}\text { In-house, Mayo Clinic, MN, } \\
\text { USA }\end{array}$ \\
\hline Inbred mouse colony (1); male mice & CF-1 ${ }^{\mathrm{TM}}$ & $\begin{array}{l}\text { Charles River, San Diego, } \\
\text { CA, USA }\end{array}$ \\
\hline \multicolumn{3}{|l|}{ Special materials } \\
\hline anti-rabbit IgG (Fab fragment) & $\begin{array}{l}\text { Alexa } \\
\text { Fluor® }\end{array}$ & $\begin{array}{l}\text { Life Technologies, Carlsbad; } \\
\text { CA, USA }\end{array}$ \\
\hline $\begin{array}{l}\text { rabbit anti- mouse monoclonal lgG } \\
\text { (whole antibody) }\end{array}$ & $\begin{array}{l}\text { Alexa } \\
\text { Fluor® }\end{array}$ & $\begin{array}{l}\text { Life Technologies, Carlsbad; } \\
\text { CA, USA }\end{array}$ \\
\hline
\end{tabular}




\begin{tabular}{|l|l|l|}
\hline $\begin{array}{l}\text { 5-(and-6)-chloromethyl-2',7'- } \\
\text { dichlorodihydrofluorescein diacetate }\end{array}$ & $\begin{array}{l}\mathrm{CM}- \\
\mathrm{H}_{2} \text { DCFDA }\end{array}$ & $\begin{array}{l}\text { Invitrogen, Molecular probes, } \\
\text { Eugene, Oregon, USA }\end{array}$ \\
\hline $\begin{array}{l}\text { 5-bromo-4-chloro-3-indoyl } \beta \text {-D- } \\
\text { galactopyranoside }\end{array}$ & X-gal & $\begin{array}{l}\text { American Bioanalytical, } \\
\text { Natick, MA, USA }\end{array}$ \\
\hline
\end{tabular}




\subsection{Methods}

\subsubsection{Embryo Collection and Culture}

All procedures involving animals were approved by the Animal Ethics Committee, the Mayo Clinic Institutional Animal Care and Use Committee (IACUC).

Female FVB mice (4-7 weeks old) were superovulated with intraperitoneal injections of $5 \mathrm{IU}$ pregnant mare's serum (PMS) followed 48 hours later by 5 injections of human chorionic gonadotropin (hCG).

Female mice were caged individually with male CF-1 mice for breeding overnight and were checked for copulation by observing a vaginal plug of semen the next morning. Pregnant mice with vaginal plugs were euthanized at 18-20 hours post-hCG, oviducts excised and flushed with human tubal fluid medium (HTF-medium) containing 4-(2-hydroxyethyl)-1piperazineethanesulfonic acid buffer (HEPES-buffer) and $5 \mathrm{mg} / \mathrm{ml}$ human serum albumin (HSA).

One-cell embryos were cultured in groups $(2 \mu$ media per embryo) in tissue culture dishes (3001) in Global medium under embryo-tested laboratory grade mineral oil with and without protein supplementation (10\% Serum Substitute Supplement) in $37^{\circ} \mathrm{C}$ humidified atmospheres at $5 \%$ and $20 \% \mathrm{O}_{2}, 6.5 \% \mathrm{CO}_{2}$, $72.5 \% \mathrm{~N}_{2}$ in modular $\mathrm{CO}_{2}$ water incubator chambers.

Dishes were prepared at least 24 hours before embryo collection and contained 5 media drops of $30 \mu l$ each and were allowed to equilibrate in the incubator chambers with a minimum of 8 and maximum of 16 hours at their specific $\mathrm{O}_{2}$ level to reach target $\mathrm{pH}(7.3-7.4)$.

Embryo handling was performed with a micropipetter (using $125 \mu \mathrm{m}$ tips). Latex gloves were worn during all procedures involving embryo handling to avoid additional contamination and in order to obtain sterile working conditions to a certain degree. 
A maximum amount of fifteen embryos were included in each drop of medium ( 1 embryo per $2 \mu$ l media) and embryos were randomly assigned to one out of four separate tissue culture dishes used for each experiment.

Experiment 1: Effects of oxygen and protein on markers of cellular senescence

\begin{tabular}{|l|l|l|}
\hline $\begin{array}{l}\text { Culture conditions for } \\
\text { different treatment } \\
\text { groups (TG) for } \\
\text { Experiment 1 }\end{array}$ & $5 \% \mathrm{O}_{2}$ & $20 \% \mathrm{O}_{2}$ \\
\hline $\begin{array}{l}\text { Global medium } \\
+ \text { SSS (protein) }\end{array}$ & TG 1 & TG 3 \\
\hline $\begin{array}{l}\text { Global medium } \\
\text { (no protein supplement) }\end{array}$ & TG 2 & TG 4 \\
\hline
\end{tabular}

Figure 1 Post collection embryos used for Experiment 1 (2x2 factorial design) were cultured 96 hours respectively in one out of four treatment groups (TG); TG1: 5\% $\mathrm{O}_{2}$ with SSS supplementation; TG2: $5 \% \mathrm{O}_{2}$ without SSS supplementation; TG3: $20 \% \quad \mathrm{O}_{2}$ with SSS supplementation; TG4: $20 \% \mathrm{O}_{2}$ without SSS supplementation

Experiment 2: Effects of oxygen and protein on ROS formation in live blastocysts

\begin{tabular}{l|l|l|}
\hline $\begin{array}{l}\text { Culture conditions for } \\
\text { different treatment } \\
\text { groups (TG) for } \\
\text { Experiment 2 }\end{array}$ & $5 \% \mathrm{O}_{2}$ & $20 \% \mathrm{O}_{2}$ \\
\hline $\begin{array}{l}\text { Global medium } \\
+ \text { SSS (protein) }\end{array}$ & TG 1 & \\
\hline $\begin{array}{l}\text { Global medium } \\
\text { (no protein supplement) }\end{array}$ & & TG 2 \\
\hline
\end{tabular}

Figure 2 Post collection embryos used for Experiment 2 were cultured 96 hours respectively in one out of two treatment groups (TG); TG1: $5 \% \mathrm{O}_{2}$ with SSS supplementation; TG2: $20 \% \mathrm{O}_{2}$ without SSS supplementation.

Embryos were cultured in their assigned culture conditions for 96 hours post embryo collection until reaching the blastocyst stage and development was surveyed every 24 hours.

Blastocysts at the expanded and/ or hatching stage after 96 hours post collection were included in the study. 
A minimum of 3 replicates and a total number of 30 blastocysts $(n=30)$ were used for each marker studied.

Experiment 1: After 96 hours of culture, blastocysts from each experimental group were washed three times in phosphate-buffered saline (PBS; $\mathrm{pH}=7.4$ ) containing $0.1 \%$ polyvinyl alcohol (PVA) and were either immediately stained for SA-B-Galactosidase or $\mathrm{Y}-\mathrm{H} 2 \mathrm{~A} . \mathrm{X}$ and DAPI.

Experiment 2: After 96 hours of culture, blastocysts from each experimental group were directly rinsed with pre-warmed final working solution of the CM$\mathrm{H}_{2}$ DCFDA assay after removal from their specific, experimental group dependent growth medium.

\subsubsection{Experiment 1:}

\subsubsection{Senescence-associated B-galactosidase Assay}

Prior to the commencement of the assay, the following accessories were set up and solutions freshly prepared:

1) Four petri dishes, one for each treatment group, containing three rows composed of three drops à $30 \mu$ each.

- First row: phosphate buffered saline- polyvinyl-alcohol (PBS-PVA)

- Second row: fixation solution (composition see below);

- Third row: PBS-PVA

With a serological glass pipet $(5 \mathrm{ml})$ all nine drops were covered with $3 \mathrm{ml}$ of mineral oil (stored at room temperature in the dark), to prevent drops from desiccating.

2) Fixation solution: containing $2 \%$ paraformaldehyde and $0.2 \%$ glutaraldehyde in PBS-PVA: 
For a total of 3ml:

- $24 \mu \mathrm{l}$ gluteraldehyde (stored at $-80^{\circ} \mathrm{C}$ ) were mixed with

- $246 \mu$ l formaldehyde (stored at room temperature) and diluted in

- 2.7 ml PBS-PVA

Fixative was stored in $5 \mathrm{ml}$ polypropylene round-bottom tubes.

\section{3) SA-B-galactosidase staining solution:}

- $50 \mu l X-g a l$

- $200 \mu \mathrm{l} 0.2 \mathrm{M}$ citric acid $(\mathrm{pH}=6.0)$

- $50 \mu \mathrm{l}$ 100mM potassium ferrocyanide

- $50 \mu \mathrm{l} 100 \mathrm{mM}$ potassium ferracyanide

- $\quad 30 \mu \mathrm{l} 5 \mathrm{M}$ sodium chloride

- $\quad 2 \mu \mathrm{l} 1 \mathrm{M}$ magnesium chloride

- $620 \mu l$ molecular water

With a precision micro liquid transfer device (pipet-aid) all ingredients were compounded in a $1.5 \mathrm{ml}$ microtube and mixed each time with the pipette when a new substance was added. The Microtube was directly closed and stored UV-light protected (covered with aluminum foil) at room temperature.

A positive control for B-galactosidase activity was performed at $\mathrm{pH}$ 4.0. Therefore a different staining solution was prepared with the same ingredients as stated above, except for citric acid:

- $200 \mu \mathrm{l} 0.2 \mathrm{M}$ citric acid $(\mathrm{pH}=4.0)$ 


\section{Staining method:}

Embryo handling was performed with a micropipetter.

Each experimental group was washed three times by using the first row of prepared PBS-PVA drops to free the blastocysts from cumulus cells and other impurities.

To fix and permeabilize the cells, blastocysts were rinsed in the first two drops of fixative and then left in the third drop for 10 minutes at room temperature.

To rinse off remnants of fixation solution, blastocysts were washed three times by using the third row of fresh drops of PBS-PVA and stored in the last drop at $4^{\circ} \mathrm{C}$ for a short time if necessary.

Blastocysts were added to $0.5 \mathrm{ml}$ of the SA-B-galactosidase stain in a four-well dish and incubated for 16 hours in a $\mathrm{CO}_{2}$-free incubator at $37^{\circ} \mathrm{C}$ covered in aluminum foil to shield from UV-light influence.

Following the incubation period, the blastocysts were washed extensively with $0.5 \mathrm{ml}$ PBS-PVA in a second four-well dish and immediately assessed using a light microscope at 400x magnification.

Embryos were considered positive when blue precipitate was apparent.

Assay results were assessed by two independent observers blinded to the treatments. 


\subsubsection{Gamma -H2A.X Immunofluorescence Staining}

Prior to the implementation of the assay, the following stock solutions were prepared:

\section{1) $4 \%$ Fixation solution:}

- From stock, $16 \%$ paraformaldehyde $(10 \mathrm{ml}$ vial) was diluted with $30 \mathrm{ml}$ PBS.

Fixative was stored in $50 \mathrm{ml}$ polypropylene round-bottom tubes at room temperature.

2) $10 \%$ Tween20:

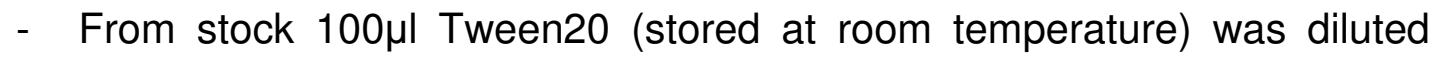
with $10 \mathrm{ml}$ PBS and stored in $50 \mathrm{ml}$ polypropylene round-bottom tubes at room temperature.

3) $1 \%$ Triton $X-100$ :

- From stock $100 \mu \mathrm{l}$ TX100 was diluted in $10 \mathrm{ml}$ PBS and stored in $50 \mathrm{ml}$ polypropylene round-bottom tubes at room temperature.

\section{4) Blocking solution (8\% BSA/ PBS):}

- From stock $0.8 \mathrm{~g}$ bovine serum albumin (BSA) powder was mixed with $10 \mathrm{ml}$ PBS on a magnetic stirrer plate until dissolved and stored in $20 \mathrm{ml}$ polypropylene round-bottom tubes at $4 \stackrel{\circ}{\circ}$.

\section{5) Antibodies:}

- Primary antibody (1:300): $1 \mu \mathrm{l}$ rabbit anti-mouse monoclonal IgG was diluted with 299 ul of $1 \%$ BSA/PBS.

- Secondary antibody (1:500): $1 \mu$ l anti-rabbit IgG was diluted with 499ul of $1 \%$ BSA/PBS.

Antibodies were stored in micro tubes at $4^{\circ} \mathrm{C}$ in the dark.

- $1 \%$ BSA/ PBS: From stock $0.1 \mathrm{~g}$ BSA powder was mixed with 10ml PBS on a magnetic stirrer plate until dissolved and stored in $20 \mathrm{ml}$ polypropylene round-bottom tubes at $4^{\circ} \mathrm{C}$. 
6) Staining:

A stock solution of 3\% 4'-6-Diamidino-2-phenylindole (DAPI) in Vectashield mounting medium was available in the IVF laboratory of the Mayo Clinic.

Dish preparation, each time prior to assay implementation:

- One dish was used respectively for each treatment group.

- Fixation: 3 drops of $30 \mu$ fixation solution in a polystyrene Petri dish covered with mineral oil.

- Permeabilization:

1) 3 drops of $30 \mu l 0.1 \%$ Tween 20 in a Petri dish covered with mineral oil.

2) $0.5 \mathrm{ml}$ of $1 \% \mathrm{TX} 100$ in a tissue culture dish

- Blocking solution: $0.5 \mathrm{ml} 8 \% \mathrm{BSA} / \mathrm{PBS}$ in a 4-well-dish

- Incubation with antibody:

1) Three drops (each $50 \mu \mathrm{l}$ ) of 1:300 diluted primary antibodies in a Petri dish covered with mineral oil.

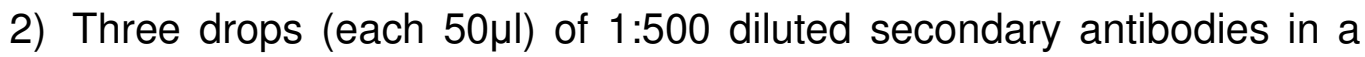
Petri dish covered with mineral oil.

- Intermediate washing/ permeabilization: Two additional plates with 3 drops of $30 \mu \mathrm{l} 0.1 \%$ Tween20 in a Petri dish covered with mineral oil.

- Staining: $40 \mu \mathrm{l}$ of vectashield containing $3 \%$ DAPI (in the middle of the concavity) of an object slide 


\section{Immunofluorescence staining procedure for embryos on slides:}

Each experiment group was treated separately. Embryos were washed through two drops of fixative and left in the third drop of $4 \%$ paraformaldehyde in PBS under mineral oil for one hour at $4^{\circ} \mathrm{C}$.

Afterwards, embryos were washed three times in PBS with $0.1 \%$ Tween 20 , where they were left in each drop for 15 minutes at $4{ }^{\circ} \mathrm{C}$ and were then permeabilized in PBS with $1.0 \%$ Triton $\mathrm{X}-100$ for one hour at $4^{\circ} \mathrm{C}$.

Following, embryos were washed three times in PBS with $0.1 \%$ Tween20 and were then blocked in PBS containing $8 \% \mathrm{BSA}$ in a 4-well dish overnight at $4{ }^{\circ} \mathrm{C}$.

Embryos were then stained for 12 hours with the primary antibody (rabbit antimouse monoclonal $\lg G$ ) overnight at $4^{\circ} \mathrm{C}$ using a dilution of $1: 300$ in $1 \%$ BSA/PBS.

Upon incubation, embryos were washed three times in PBS with $0.1 \%$ Tween20, where they were left in each drop for 10 minutes at $4^{\circ} \mathrm{C}$ and were then incubated with the secondary antibody (anti-rabbit lgG) using a dilution of $1: 500$ in 1\% BSA/PBS for 2 hours at room temperature in the dark.

The immunostained embryos were washed again three times in PBS with $0.1 \%$ Tween20 at $4^{\circ} \mathrm{C}$ on an orbital shaker (speed: $30 / \mathrm{min}$ ) where they were left in each drop for 15 minutes.

Embryos were then counterstained with 3\% DAPI in Vectashield mounting medium, whilst thawing a maximum of 5 embryos per object slide onto $40 \mu \mathrm{l}$ of vectashield/3\% DAPI. The object slide concavity was covered with a cover slide and sealed with nail polish. Either evaluation with a confocal microscope (Zeiss LSM780) was performed directly to detect the fluorescent dye and obtain confocal images or slides were stored in the dark at $4^{\circ} \mathrm{C}$ with the cover slides down for subsequent evaluation.

Blastocysts were scanned 3-dimensionally using the Z-stack function and Zstack images were projected as overlay. Each nucleus of a blastomere with more than 5 detectable foci was considered as $\mathrm{Y}-\mathrm{H} 2 \mathrm{~A} . \mathrm{X}$ positive.

Scoring was performed by two individuals blinded to the treatments. 


\subsubsection{Experiment 2: $\mathrm{CM}-\mathrm{H}_{2}$ DCFDA Assay}

Before the start of each experiment following stock solution and accessories needed to be prepared:

1) Concentrated stock solution (3mM), before using 5-(and-6)chloromethyl-2',7'-dichlorodihydrofluorescein diacetate (CM- $\left.\mathrm{H}_{2} \mathrm{DCFDA}\right)$ for the first time :

- $28.3 \mu \mathrm{l}$ dimethylsulfoxide (DMSO) were added to $\mathrm{CM}-\mathrm{H}_{2}$ DCFDA.Solution was kept tightly sealed until ready to use.

2) Two petri dishes (1006): equipped with two $30 \mu \mathrm{l}$ drops of $4-(2-$ hydroxyethyl)-1-piperazineethanesulfonic acid-buffer (Hepes buffer) covered with mineral oil, preheated (1hour) to reach optimal embryo culture temperature $\left(37^{\circ} \mathrm{C}\right)$ in a $\mathrm{CO}_{2}$ Incubator $\left(6.5 \% \mathrm{CO}_{2}\right)$.

3) PBS-PVA (600 $\mathrm{ll}$ ): in $5 \mathrm{ml}$ polystyrene round-bottom tubes (sterile, graduated, with screw cap) preheated (1hour) to reach optimal embryo culture temperature $\left(37^{\circ} \mathrm{C}\right)$ in a $\mathrm{CO}_{2}$ Incubator $\left(6.5 \% \mathrm{CO}_{2}\right)$; needed for concentrated working solution/ buffer media.

4) Final working solution $(5 \mu \mathrm{M})$; each time freshly prepared before the start of experiment:

- $1 \mu$ l of stock solution was added to $600 \mu$ of PBS-PVA buffer

- Two drops of final working solution were prepared in a petri dish: First drop of $100 \mu \mathrm{l}$, second drop of $500 \mu \mathrm{l}$

\section{Staining method:}

$\mathrm{CM}-\mathrm{H}_{2}$ DCFDA was freshly diluted to $5 \mu \mathrm{M}$ with PBS-PVA buffer from a concentrated stock solution of $3 \mathrm{mM}$ in DMSO.

Blastocysts from two experimental groups $\left(5 \% \mathrm{O}_{2}\right.$ with protein and $20 \% \mathrm{O}_{2}$ without protein) were removed from their specific, experimental group

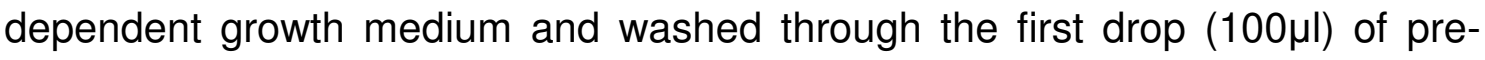
warmed final working solution (PBS-PVA buffer containing the fluorescent dye) 
and left in the second drop $(500 \mu \mathrm{l})$ for incubation in the presence of CM$\mathrm{H}_{2}$ DCFDA at $37^{\circ} \mathrm{C}$ for 30 minutes in a $\mathrm{CO}_{2}$ Incubator $\left(6.5 \% \mathrm{CO}_{2}\right)$.

Embryos were then washed twice through drops $(30 \mu \mathrm{l})$ of prewarmed dye-free Hepes buffer to remove traces of the dye, placed seperately within $2 \mu l$ of Hepes buffer on a glass dish under mineral oil and were immediately analyzed with a laser scanning confocal microscope (Zeiss LSM780), using excitation of 492$495 \mathrm{~nm}$ and emission wavelength of $515-565 \mathrm{~nm}$.

A digital camera attached to the microscope acquired the images 3dimensionally using the Z-stack function and the mean intensity of the dye was measured from an overlay of the Z-stack images obtained from one blastocyst.

Images were taken in normal display as well as artificial pseudo color palette rainbow display. 


\subsection{Statistical Analysis}

Results were analyzed by one-way analysis of variance (ANOVA) and significance was determined by the Student $t$ test.

$P$ values less than 0.05 were considered statistically significant.

All diagrammatic representations are shown with their respectively standard error of the mean (SEM).

Analysis was performed using JMP software (SAS Institute, Inc) and Prism (GraphPad Software, Inc). 


\section{Results}

\subsection{Culture in 5\% oxygen reduced markers of cellular senescence to levels similar to those seen in-vivo}

\subsection{1 $5 \% \mathrm{O}_{2}$ environment revealed lowest Senescence-associated B- galactosidase staining}

Lysosomal $\beta$-D-Galactosidase (encoded by GLB1-gene) is a hydrolase, present in lysosomes of all cells with an optimal $\mathrm{pH}$ of 4.0 that cleaves the terminal betagalactose from ganglioside substrates and other glycoconjugates. Due to its highly increased enzymatic activity in senescent cells, its' so called "senescent associated activity" is sufficient to be measured at an otherwise suboptimal pH of 6.0 and therefore is distinguishable from detection in non-senescent cells.

By applying a cytochemical assay, GLB1-gene expression can be detected.

Fixed cells are incubated with the chromogenic substrate X-gal (5-bromo-4chloro-3-indoyl $\beta$-D-galactopyranoside) which is hydrolyzed by $S A-\beta$ gal into galactose and a blue insoluble indigo dye representing SA- $\beta$ galactosidase activity. Cytochemical detection of SA- $\beta$ gal is widely used as a biomarker of cellular senescence and can be used to detect senescent cells in embryos.

For each treatment group a total number of 30 blastocysts $(n=30)$ was assessed. Embryos were considered positive when blue precipitate was apparent. Assay results were assessed by two independent observers blinded to the treatments. 


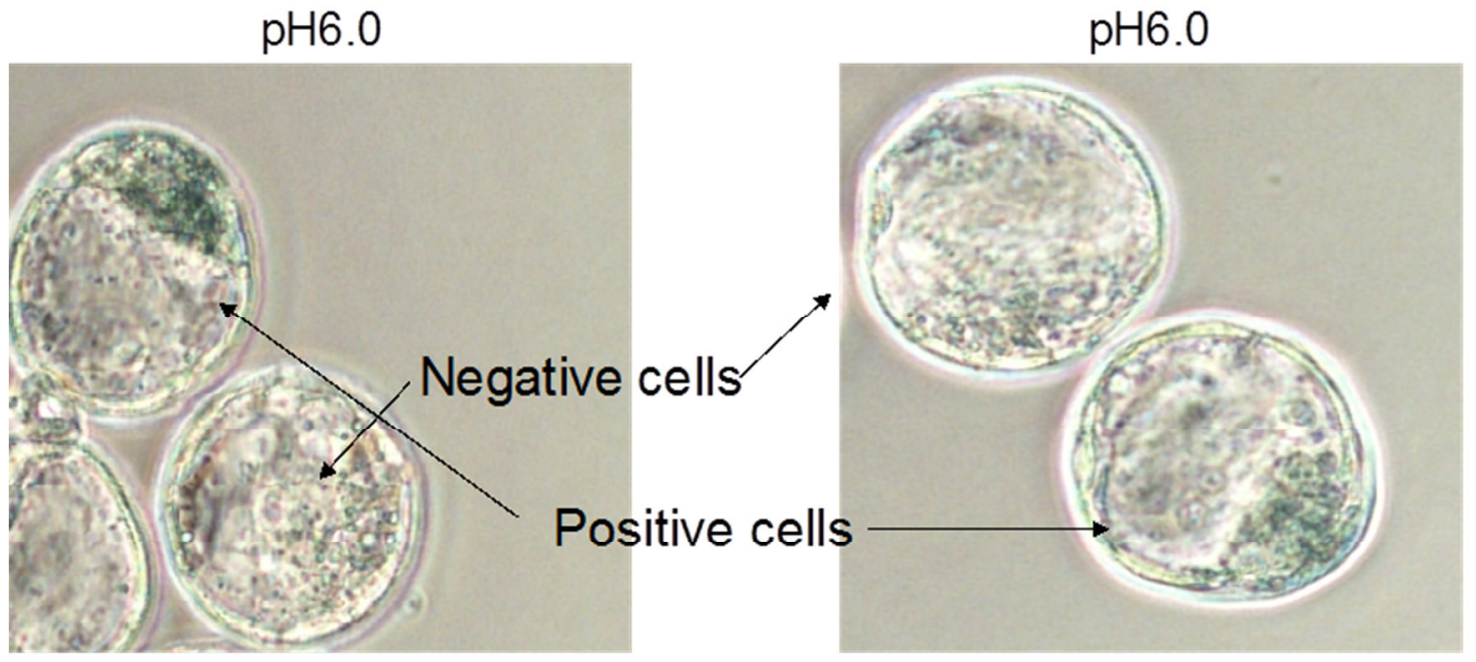

Figure 3 Representative images of murine blastocysts developed in vitro in different culture conditions, after staining for senescence-associated (SA-) $\beta$-galactosidase (blue color; original magnification, $\times 400)$.

Blastocysts cultured in $20 \%$ oxygen were positive for SA- $\beta$-galactosidase (Fig. 4); the proportion of positive blastocysts was similar for embryos cultured with or without protein supplementation ( $50.0 \%$ vs $63.3 \%$, respectively). In contrast, for blastocysts cultured in 5\% oxygen, only $10.0 \%$ stained positive for SA- $\beta$ galactosidase when protein was present but $26.7 \%$ were positive when protein was absent $(P<.05)$. 


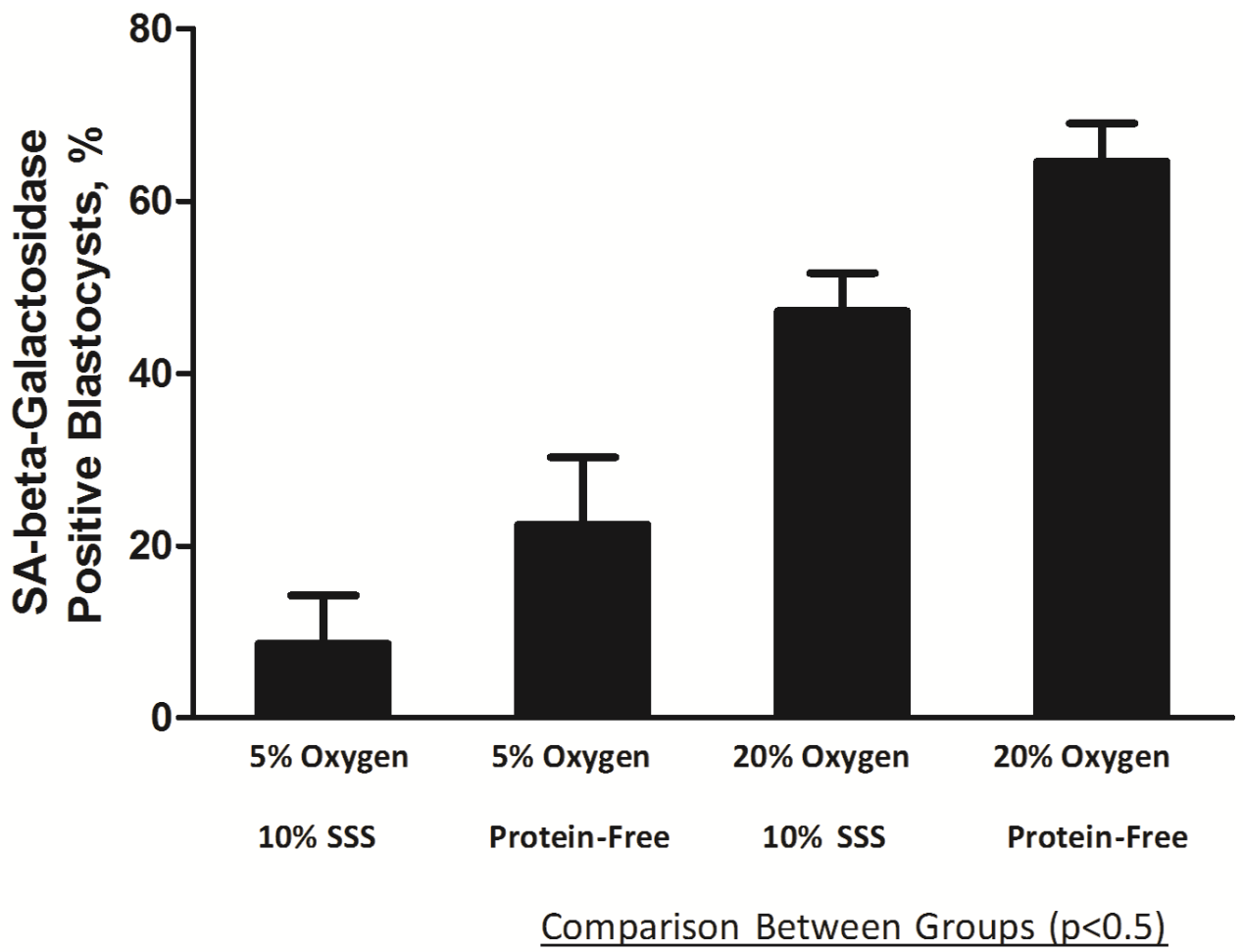

$5 \%$ Oxygen, $10 \%$ SSS

5\% Oxygen, Protein -Free

$20 \%$ Oxygen, $10 \%$ SSS

Figure 4 Percentage of blastocysts positive for senescence-associated (SA-) $\beta$-galactosidase activity, stratified by oxygen concentration and protein supplementation. Data shown are mean \pm standard error. All culture conditions were compared individually in all possible combinations (each row shows the comparison with the condition indicated for the histogram bar above); those with significant differences $(P<.05)$ are indicated $(+)$. SSS denotes serum substitute supplement

This study demonstrates for the first time that SA- $\beta$ - galactosidase is expressed to a varyingly extent in blastocysts developed in different in-vitro culture conditions.

As an internal control the B-galactosidase-assay was performed at $\mathrm{pH} 4.0$ and all experimental groups were positive for ß-galactosidase (data not shown). 


\subsubsection{The lowest amount of $\mathrm{Y}-\mathrm{H} 2 \mathrm{AX}$ positive stained embryos was shown in reduced $(5 \%)$ oxygen concentrations with protein supplementation}

\section{$\rightarrow$ In addition $20 \%$ oxygen without protein conditions seems to reduce cell number in blastocysts}

DNA double strand breaks/ telomere uncapping induce a DNA damage response leading to phosphorylation of Ser-139 of histone H2A.X molecules resulting in phosphorylated H2A.X (Y-H2A.X) adjoining to the site of DNA damage. According to present knowledge, $Y$-H2A.X foci have not yet been detected in blastocysts derived from different in-vitro culture conditions in such a setting before.

For each treatment group a total number of 30 blastocysts $(n=30)$ was assessed.

Following fixation, permeabilization and blocking, blastocysts were immunostained with a primary antibody (rabbit anti-mouse monoclonal $\lg G$ ) for 12 hours (overnight).

Upon incubation, embryos were washed and then incubated with a secondary antibody (anti-rabbit $\lg G$ ). Embryos were then counterstained with 3\% 4'-6Diamidino-2-phenylindole (DAPI) in Vectashield mounting medium.

Evaluation with a confocal microscope (Zeiss LSM780) was performed to detect the fluorescent dye and obtain confocal images. Blastocysts were scanned 3dimensionally using the Z-stack function and Z-stack images were projected as overlay and acquired in normal display as well as artificial pseudo color palette rainbow.

Each nucleus of a blastomere with more than five foci was considered as $Y$ H2A.X positive.

Scoring was performed by two individuals blinded to the treatments. 


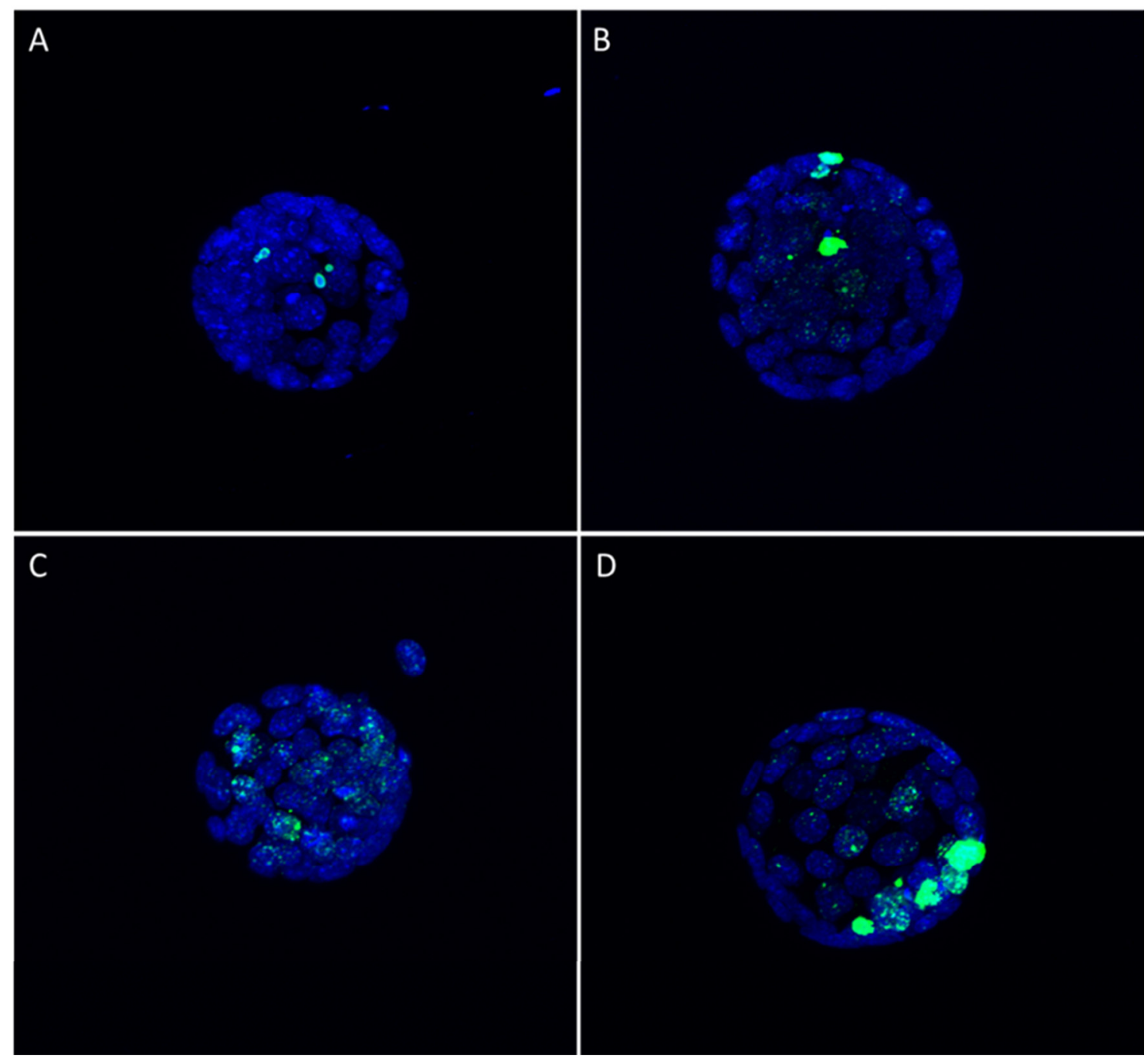

Figure 5 In-vitro blastocysts stained with DAPI (blue) and overlaid with $\mathrm{y}-\mathrm{H} 2 \mathrm{~A} . \mathrm{X}$ (green) from different experimental culture conditions: A.) $5 \%$ oxygen with protein; B.) $5 \%$ oxygen without protein; C.) $20 \%$ oxygen with protein; D.) $20 \%$ oxygen without protein; DAPI denotes 4', 6diamidino-2- phenylindole; $\mathrm{Y}$-H2A.X, phosphorylated histone H2A.X; Fluorescence microscopy performed in confocal mode (Zeiss LSM 780), normal display. 


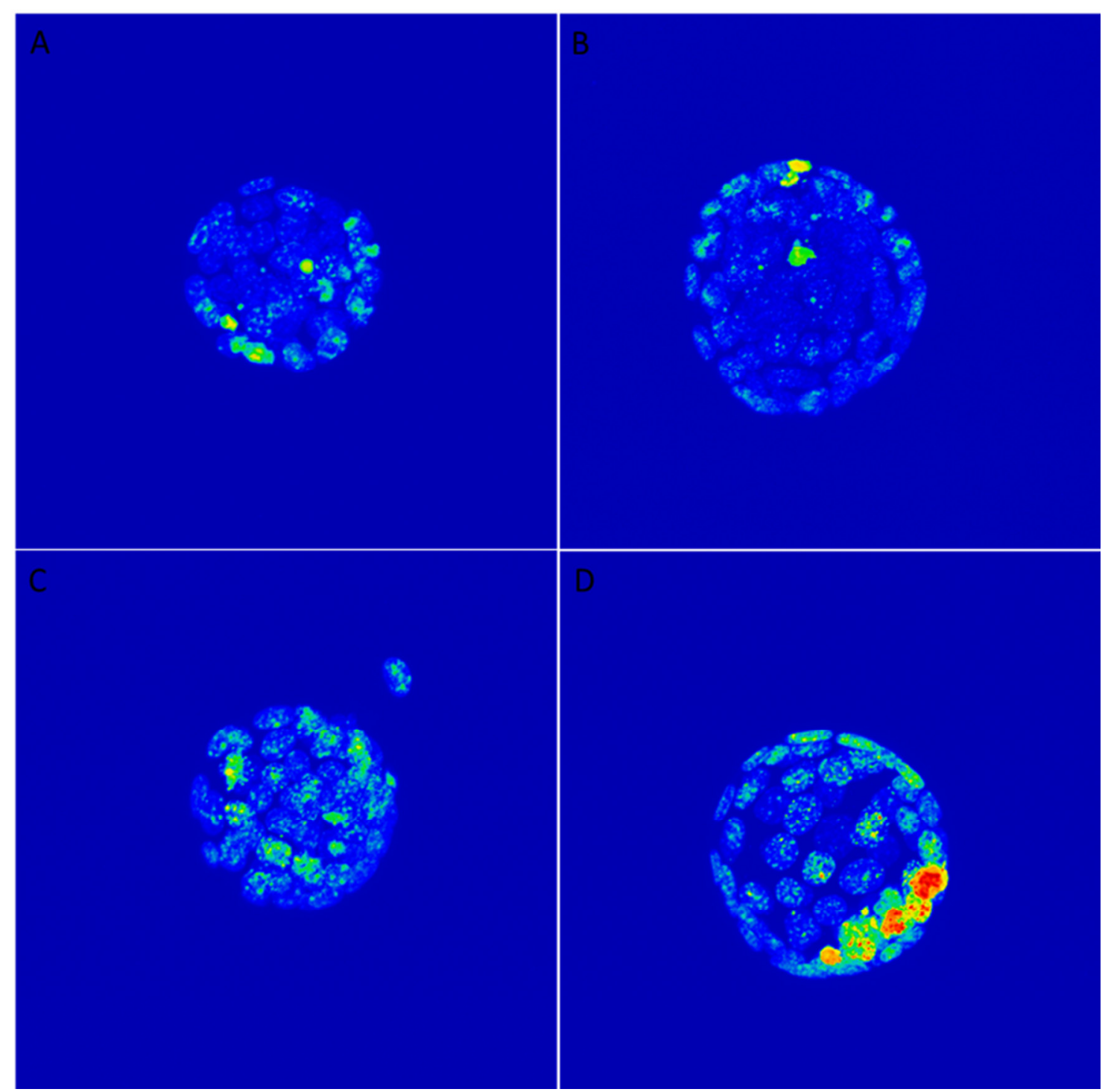

Figure 6 Presents images from Figure 5 in the artificial pseudo color palette rainbow display; highlighting the intensity of the increased amount of gamma-H2A.X positive stained blastomeres in ascending order as following: blue-green-yellow-orange-red.

The DNA damage repair response marker, $\mathrm{Y}-\mathrm{H} 2 \mathrm{~A} . \mathrm{X}$, was similarly affected by oxygen and by protein in the reduced oxygen group (Fig. 7). Fewer blastomeres per blastocyst in the reduced-oxygen group, with or without protein supplementation, had at least 5 foci in the nucleus (2.8 vs $11.2 \%$, respectively) compared with blastocysts in the $20 \%$ oxygen group $(29.3 \%$ vs $36.0 \%$, respectively; $\mathrm{P}<.05)$. Although blastocyst development for all treatment groups exceeded $75 \%$, total cell numbers were reduced in the group cultured in $20 \%$ oxygen without protein supplementation $(\mathrm{P}<.01$; Fig. 8). 


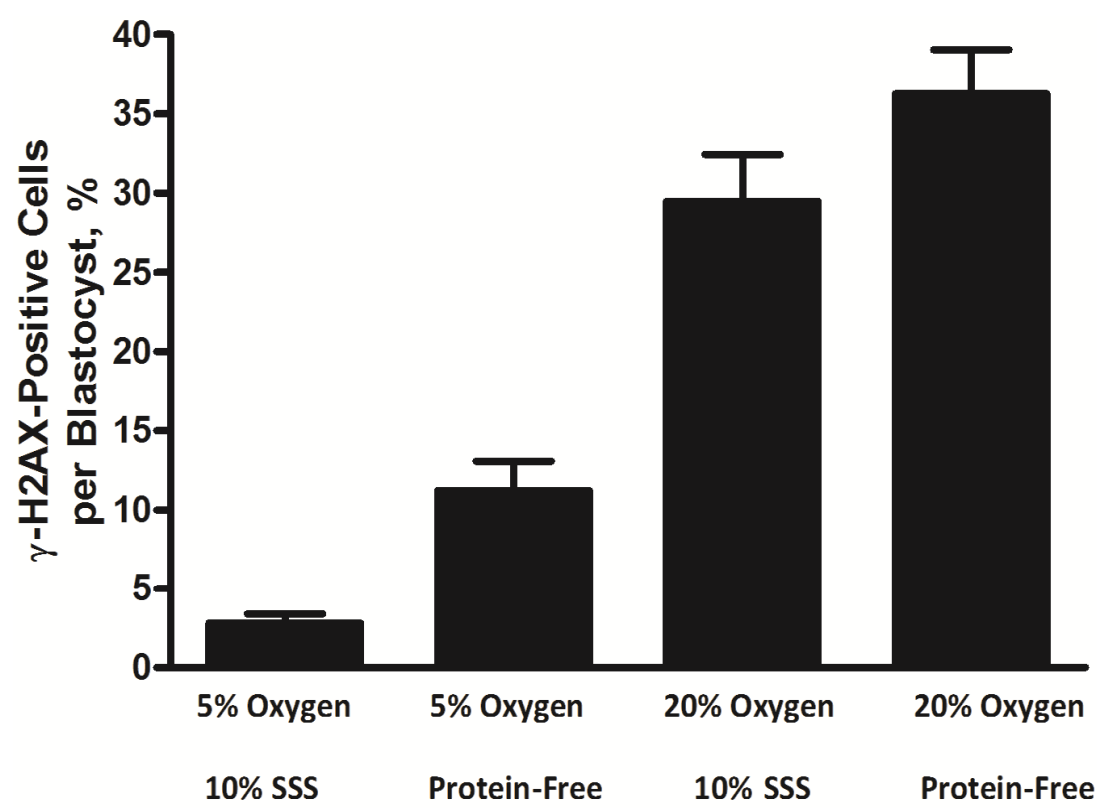

Comparison Between Groups $(p<0.5)$

5\% Oxygen, $10 \%$ SSS

5\% Oxygen, Protein -Free

$20 \%$ Oxygen, $10 \%$ SSS

Figure 7 Percentage of cells in each blastocyst positive for $\mathrm{Y}-\mathrm{H} 2 \mathrm{~A} . \mathrm{X}(>5 \mathrm{Y}-\mathrm{H} 2 \mathrm{~A} . \mathrm{X}$ foci/nucleus), stratified by oxygen concentration and protein supplementation. Data shown are mean \pm standard error. All culture conditions were compared individually in all possible combinations (each row shows comparison with the condition indicated for the histogram bar above); those with significant differences $(\mathrm{P}<.05)$ are indicated $(+)$. SSS denotes serum substitute supplement

These results may indicate that elevated oxygen concentrations during embryo culture lead to increased occurrence of DNA double strand breaks resulting in enhanced DNA repair mechanisms.

Cell stress might also lead to embryo lethality because of the loss of a critical number of cells. Figure 8 shows the number of cells per blastocyst for each oxygen and protein supplementation group. 


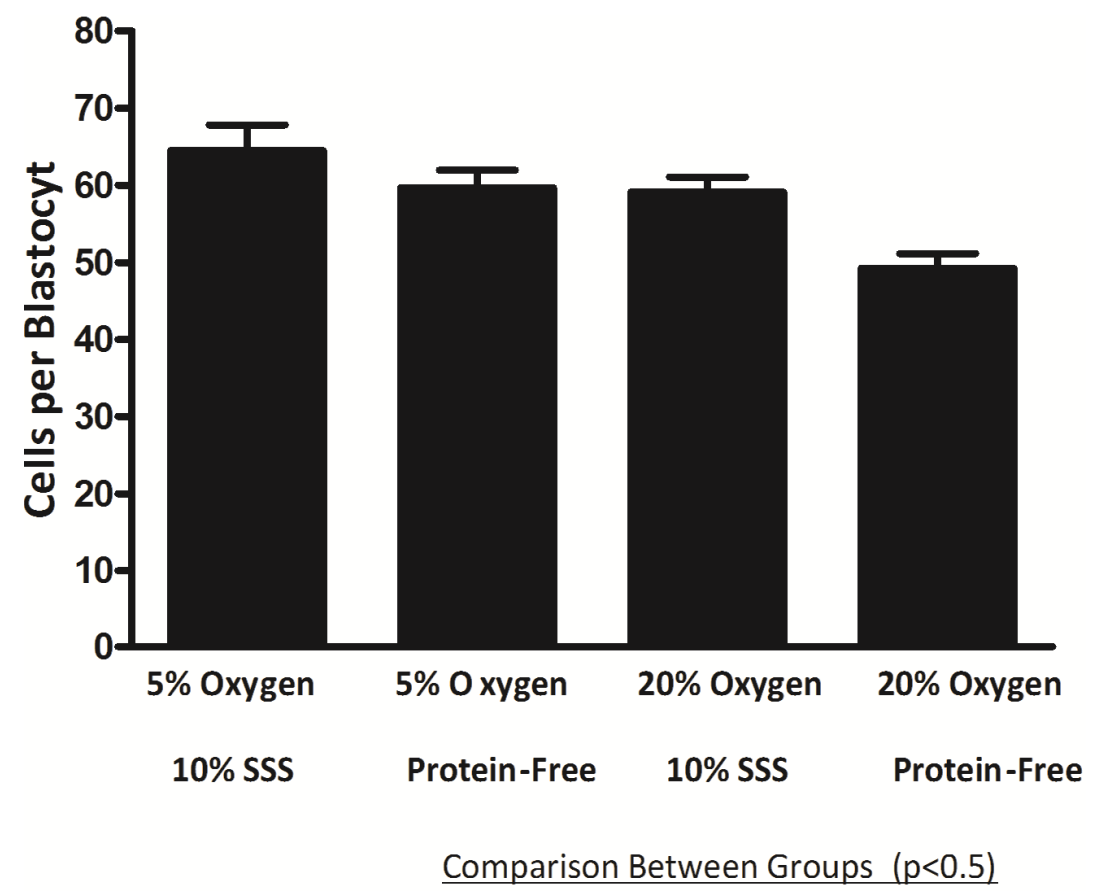

\section{5\% Oxygen, $10 \%$ SSS \\ 5\% Oxygen, Protein -Free \\ $20 \%$ Oxygen, $10 \%$ SSS}

Figure 8 Number of cells per blastocyst for each oxygen and protein supplementation group. Data shown are mean \pm standard error. All culture conditions were compared individually in all possible combinations (each row shows comparison with the condition indicated for the histogram bar above); those with significant differences $(P<.05)$ are indicated $(+)$. SSS denotes serum substitute supplement.

Total cell numbers were significantly reduced in the $20 \% \quad \mathrm{O}_{2}$ group without protein supplementation. This observation might reveal that blastocysts and their repair mechanisms decompensate in response to a certain amount of cell stress, leading to mitotic arrest or embryo lethality at some point. 


\subsection{Intracellular ROS levels in live blastocysts were reduced by $5 \% \mathrm{O}_{2}$ culture}

5-(and-6)-chloromethyl-2',7'-dichlorodihydrofluorescein-diacetate (CM$\mathrm{H}_{2}$ DCFDA ) can be used as an indicator for ROS in live cells: the fluorogenic marker for reactive oxygen species passively diffuses into cells, where its acetate groups are cleaved by intracellular esterases and its thiol-reactive chloromethyl group reacts with intracellular glutathione and other thiols. Subsequent oxidation yields a fluorescent adduct that is trapped inside the cell and mean staining intensity can be measured using fluorescence microscopy.

Up to present knowledge this method was adjusted to blastocysts and used in such a setting for the first time. Therefore optimal dye-loading concentration, temperature, incubation and recovery retention time were adapted to assumed favorable conditions for this cell type and chosen for due to practical experience.

A total number of 30 blastocysts $(n=30)$ from the $5 \% \mathrm{O}_{2}$ culture with protein and $20 \% \mathrm{O}_{2}$ culture without protein were assessed respectively.

After loading live blastocysts with the fluorescent dye, they were immediately analyzed with a laser scanning confocal microscope (Zeiss LSM780), using excitation of $492-495 \mathrm{~nm}$ and emission wavelength of $515-565 \mathrm{~nm}$.

A digital camera attached to the microscope acquired the images 3dimensionally using the Z-stack function and the mean intensity of the dye was measured from an overlay of the Z-stack images obtained from one blastocyst.

Images were taken in normal display as well as in artificial pseudo color palette rainbow. 


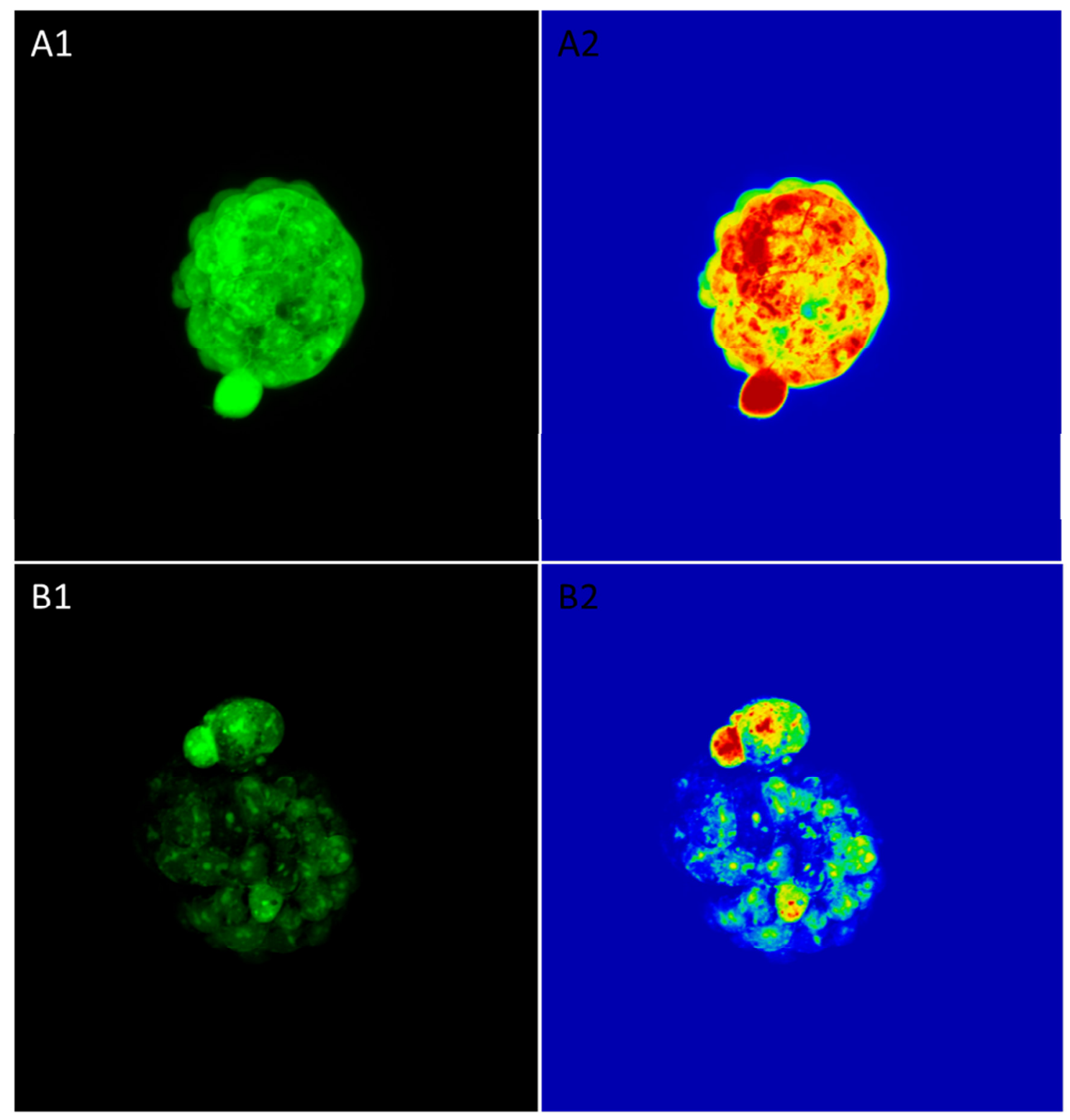

Figure 9 ROS detection with $\mathrm{CM}-\mathrm{H}_{2} \mathrm{DCFDA}$ staining in blastocysts cultured at atmospheric oxygen $(20 \%)$ levels without protein (A), compared to blastocysts cultured at $5 \%$ oxygen levels with protein (B). Fluorescence microscopy performed in confocal mode (Zeiss LSM 780); A1/B1: normal display; A2/B2: Artificial pseudo color palette rainbow

An increase in the fluorescence intensity emitted by $\mathrm{CM}-\mathrm{H}_{2} \mathrm{DCFDA}$ fluorescent dye was detected in embryos cultured under elevated oxygen culture conditions without protein supplement. These results may indicate that intracellular ROS levels can be increased by $20 \% \mathrm{O}_{2}$ culture. 


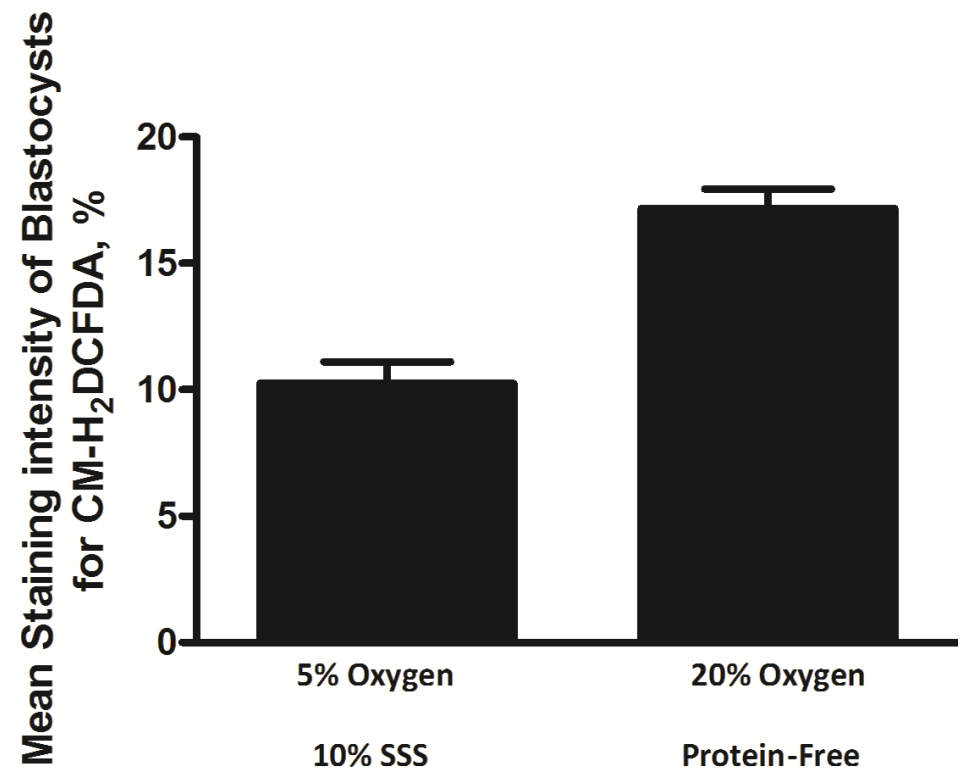

Figure 10 Percentage of mean staining intensity of blastocysts positive for $\mathrm{CM}-\mathrm{H}_{2} \mathrm{DCFDA}$ activity, stratified by oxygen concentration and protein supplementation. Data shown are mean \pm standard error. $p<0.0001$

Measured mean intensity of the fluorescent dye in live blastocysts revealed a significant difference between the two experimental groups of $5 \% \mathrm{O}_{2}$ with protein and $20 \% \mathrm{O}_{2}$ without protein supplementation. Mean staining intensity added up to $10.3 \%$ in the $5 \% \mathrm{O}_{2}$ group with protein, compared to $17.2 \%$ in the $20 \% \mathrm{O}_{2}$ group without protein $(\mathrm{P}<0.0001)$, as shown in Figure 10. 


\section{Discussion}

A high quantity of mammalian embryos cultured in-vitro undergoes permanent growth arrest. The first cleavage divisions are the most susceptible for failure (Leidenfrost et al., 2011) during the first five days of development to the blastocyst stage. Many embryos develop into a blastocyst but then fail to implant (L. A. Favetta et al., 2007) due to the inability to sustain viability. This might be one of the reasons why a pregnancy or live birth after embryo transfer does not occur (Crosier et al., 2001). Presumably one major risk factor is the higher exposition to stressors, present in the in-vitro culture process. However, in virtue of absence of apoptotic markers (Betts \& Madan, 2008), the reasons for arrest and the mechanisms that regulate this process are poorly understood.

When actively growing cells stop to make further progress they can enter two possible lines of fate. They either undergo programmed cell death (apoptosis) or another programmed cell response to stress: Cellular senescence. Cellular senescence describes a permanent cell cycle arrest state, which cells enter due to required cellular responses to cell damage (e.g. repair mechanisms). In a senescent-like state cells do not further divide but remain, in contrast to programmed cell death, viable and metabolically active (Hayflick \& Moorhead, 1961; Rodier \& Campisi, 2011). Cellular senescence can be induced by in-vitro stress but is classically associated with in-vivo ageing as well as tumor suppression (Hayflick \& Moorhead, 1961; Smith \& Pereira-Smith, 1996). It is characterized by the increased expression of SA-beta-galactosidase, gammaH2A.X nuclear foci, dysfunctional telomeres (J Campisi \& d'Adda di Fagagna, 2007), intracellular ROS (L. a Favetta et al., 2007), elevated stress-sensing proteins such as p66Shc (L. A. Favetta et al., 2004) as well as p16INK4a and an increase in cell size (Rodier \& Campisi, 2011). Previous studies showed that during early embryo arrest (at the 2-to 4-cell stage), cells reveal senescent-like features (Betts \& Madan, 2008), e.g. high amounts of intracellular ROS. Demonstrating the presence of these features in blastocysts, the most important developmental stage prior to implementation in the uterus cavity, is top-ranking. DNA-damaged cells in blastocysts undergo an unknown fate, but the possibilities include senescence with complete cell cycle arrest, repair with 
transient cell cycle arrest or apoptotic cell death (K Hardy, 1997; Jurisicova \& Acton, 2004). Further studies of the cellular senescence pathway in embryos, DNA damage and the role of oxidative stress in embryo culture conditions as well as coherence between all above mentioned factors are required.

In a previous study of our working group it was shown, that the representative markers of cellular senescence SA-beta galactosidase and gamma-H2A.X as well as p21 were significantly elevated in in-vitro derived blastocysts compared to in-vivo ones. These results lead to the conclusion that in-vitro culture may stress the early developing embryo to a certain extent that leads to the development of a senescent-like phenotype.

In this study of murine blastocysts it was investigated if the presence and extent of markers of cellular senescence vary under different culture conditions. Since reduced oxygen during embryo culture as well as the addition of protein (as a source of antioxidant) seemed to minimize the effects given above, it furthermore was to be investigated if ROS formation as a possible effect of elevated oxygen conditions in in-vitro culture, can be measured (via CM$\mathrm{H}_{2}$ DCFDA) in in-vitro derived live blastocysts.

Experiments in this constellation are hitherto unprecedented.

SA- $\beta$-galactosidase is an early marker of cellular senescence, a lysosomal enzyme present in most senescent cells. Classic acid $\beta$-galactosidase can be found in all eukaryotic cells in the lysosome and is distinguished from SA- $\beta$ galactosidase by its $\mathrm{pKa}$, with the former active at a $\mathrm{pH}$ of 6.0 . This study demonstrates for the first time that SA- $\beta$-galactosidase is present to a different extent in in-vitro derived murine blastocysts, influenced by culture conditions. There was a significant increase in SA- $\beta$-galactosidase activity in blastocysts cultured in $20 \%$ oxygen compared to blastocysts cultured in $5 \%$ oxygen (Fig. 4 ). Interestingly, the proportion of positive blastocysts in the $20 \%$ oxygen group was similar for embryos cultured with or without protein supplementation, in contrast to blastocysts cultured in $5 \%$ oxygen. In the $5 \%$ oxygen group SA- $\beta$-gal activity was close to in-vivo measured levels when protein was present (10\% vs. $3.3 \%$ in-vivo; Meuter, Rogmann et al., 2014) but nearly tripled when protein was absent (26.7\%). Results may indicate that in contrast to in-vivo conditions, 
culture in $5 \%$ oxygen leads already to an increase in lysosomal mass in an attempt to compensate for a higher accruing amount of oxidation products (Liton et al., 2009) but can be positively affected by the supplementation of an antioxidant source like protein. On the contrary, culture in $20 \%$ oxygen does not seem to profit specifically from additional protein anymore, assuming that a certain amount of a stressor can lead to a senescing dose (Rodier \& Campisi, 2011) if a certain threshold is reached. Although SA- $\beta$-galactosidase is the first and most extensively utilized marker to establish a senescent phenotype, the biological significance of this assay remains in question and is limited through its uncertain specificity (Lee et al., 2006; Debacq-Chainiaux et al., 2009). SA- $\beta$ galactosidase activity at $\mathrm{pH} 6$ increases in some non-senescent, e.g. differentiated cells like melanocytes (Dimri et al., 1995; Severino et al., 2000). Furthermore its activity can be detected whether cells are induced to senescence by replicative exhaustion, genotoxic or other forms of stress as well as oncogene activation (Debacq-Chainiaux et al., 2009). There exists skepticism that an elevated SA- $\beta$-galactosidase activity may simply reflect an increase in lysosomal biogenesis (Kurz et al., 2000; Zwerschke et al., 2003). But as aforementioned, an increase in lysosomal mass could be due to the compensation for a higher amount of oxidation products, resulting in higher SA$\beta$-galactosidase activity. Therefore this assay could also be used to detect intracellular changes with respect to oxidative stress. In addition, it is well known that oxidative stress resulting from mitochondrial ROS production during aging (Passos, Von Zglinicki, et al., 2007; Zwerschke et al., 2003) or exogenous ROS can lead to accumulation of oxidation products such as lipofuscin (Sitte et al., 2001).

Taken together, the importance of SA- $\beta$-galactosidase detection in embryos remains to be determined, but it could suggest an increase in lysosomal biogenesis, consistent with oxidative stress (Rogmann, Meuter et al., 2014), that under a certain extent is susceptible to antioxidant additive.

DNA damage response can be measured with phosphorylation of the histone variant H2A.X (Y-H2A.X). It is furthermore necessary for the classification of a senescent phenotype (von Zglinicki et al., 2005) and known as a highly sensitive marker of DNA damage (Mah, El-Osta, \& Karagiannis, 
2010) which forms foci at the site of double-strand breaks, causing recruitment of several DNA repair and cell cycle checkpoint proteins. In this study a threshold of at least 5 Y-H2A.X foci per nucleus was used (Lawless et al., 2010) to classify cells as senescent. $\mathrm{Y}-\mathrm{H} 2 \mathrm{~A} . \mathrm{X}$ foci were already increased in blastocysts derived from in-vitro culture settings compared to in-vivo (Meuter, Rogmann et al., 2014). The DNA damage repair response marker $\mathrm{Y}-\mathrm{H} 2 \mathrm{~A} . \mathrm{X}$ was also differently affected by in-vitro culture settings used in this study (Fig. 7). Significantly fewer blastomeres per blastocyst in the reduced-oxygen group, with or without protein supplementation, had at least 5 foci in the nucleus compared with blastocysts in the $20 \%$ oxygen group. In the $20 \%$ oxygen group there was no significant difference in the expression observed when protein was added. In contrast, the 5\% oxygen group with protein supplementation displayed even less $\mathrm{Y}$-H2A.X foci (2.8\%) than those derived in-vivo $(14.2 \%$; Meuter, Rogmann et al., 2014). Interestingly, the constellation 5\% oxygen without protein yields a similar rate $(11.2 \%)$ of detectable $\mathrm{\gamma}-\mathrm{H} 2 \mathrm{~A} . \mathrm{X}$ foci as blastocysts derived in-vivo. Results may indicate that elevated oxygen due to oxidative stress is the main contributor to DNA damage and consecutive damage response. Reduced oxygen conditions without protein seem to be comparable to in-vivo conditions. However, the role of protein remains debatable. When adding protein in low oxygen conditions, $\mathrm{Y}-\mathrm{H} 2 \mathrm{~A}$.X foci were decreased to even lower levels than experimentally verified in-vivo. Therefore it remains in question if a certain amount of radicals are necessary for proper embryo development (Murphy et al., 2011; Ufer \& Wang, 2011). Those could be scavenged when antioxidants are added to already satisfying culture environments, depriving the embryos of required reserves. One feature of senescence cells is, that growth arrest is permanent and cannot be reversed (Rodier \& Campisi, 2011). Also DNA damage response must be persistent to induce senescence (d'Adda di Fagagna, 2008). It is possible that those detected foci that are transient and repairable ones, which allow cells to continue proliferation, once restored. Although the fate of affected blastomeres is unknown, a prior study has shown that arrested 2-cell stage bovine embryos are positive for $\mathrm{Y}-\mathrm{H} 2 \mathrm{~A} . \mathrm{X}$ whereas proliferating 2-cell embryos do not show expression of $\mathrm{Y}-\mathrm{H} 2 \mathrm{~A} . \mathrm{X}$ (Betts \& King, 2001b). In addition, genotoxic stress also induces $\mathrm{Y}-\mathrm{H} 2 \mathrm{~A}$.X foci in 2-cell mouse embryos and results in cell cycle arrest 
(Mu, Jin, Farnham, Li, \& O'Neill, 2011). Obtained results indicate that components of the senescence response can be induced in embryos by stressors associated with in-vitro culture, most notably oxidative stress via elevated oxygen tension. Cell responses to stress may lead to cell cycle arrest and ultimately may affect viability or long-term development (Bedaiwy et al., 2004). The results of this and our previous study represent the potential importance for clinical assisted reproduction laboratories. They show that the senescence-like phenotype largely is due to culture in atmospheric oxygen, with 6- to 7-fold more $\mathrm{Y}$-H2A.X-positive cells for blastocysts cultured in $20 \%$ oxygen and similar levels of $\mathrm{Y}$-H2A.X-positive cells when comparing blastocysts cultured in $5 \%$ oxygen versus blastocysts cultured in-vivo.

Taken together, $\mathrm{Y}$-H2A.X may be a marker of senescence in preimplantation embryos (Betts \& Madan, 2008), indicating that embryos cultured in-vitro at $20 \%$ oxygen have a considerable number of cells with extensive DNA repair activity, likely due to oxidative stress.

"Reactive oxygen species" (ROS) is a term that encompasses a wide variety of different molecules such as superoxide, hydrogen peroxide, hydroxyl radical, nitric oxide, peroxynitrite, hypochlorous acid and singlet oxygen. In 2011, Murphy et al. described that each of these molecules is a distinct chemical entity with its own reaction preferences, kinetics, rate and site of production as well as degradation and diffusion characteristics in biological systems (Murphy et al., 2011). Normally, free radicals are produced over the course of normal cell metabolism (Harman, 1956) with mitochondria (reduction of $\mathrm{O}-\cdot 2$ to $\mathrm{H}_{2} \mathrm{O}_{2}$ and $\mathrm{OH} \cdot$ by using its electron transport chain) and the NADPH oxidase system in the cellular plasma membrane (generating $\mathrm{O}-\cdot 2$; present in various molecules e.g. neutrophils, eosinophils, monocytes, macrophages) being the major intracellular sources of produced free radicals (Halliwell, 2012). However, other radical generating systems, such as superoxide dismutase $\left(\mathrm{H}_{2} \mathrm{O}_{2}\right.$ is generated via dismutation of $\mathrm{O}-\cdot 2$ ); xanthine/ xanthine oxidase (generating both $\mathrm{O}-\cdot 2$ and $\mathrm{H}_{2} \mathrm{O}_{2}$ ) (Zielonka \& Kalyanaraman, 2010) as well as others should not be excluded. Embryos use oxygen as an energy substrate which is fundamental for their development. Nonetheless, the use of oxygen can also be hazardous due to ROS, which are formed as a natural by-product of oxygen metabolism, most 
notably the superoxide anion (O-•2) and hydroxyl radical $(\mathrm{OH} \bullet)$. As described by $\mathrm{C}$. Ufer in 2011, ROS are highly active electron acceptors and can become free radicals due to their ability to strip electrons from other molecules, which can modify and impair the function of all biological macromolecules such as proteins, lipids and DNA/RNA. As a product of $0-\cdot 2$ and metal ion catalysis, hydrogen peroxide $\left(\mathrm{H}_{2} \mathrm{O}_{2}\right)$ is not a radical in principle. Albeit both $\mathrm{H}_{2} \mathrm{O}_{2}$ and $\mathrm{O}-\cdot 2$ can form the extremely reactive $\mathrm{OH} \cdot$ which can lead to serious damage in cells (Ufer \& Wang, 2011). To this day many attempts to develop methods/ biomarkers to measure ROS have been made but were later on regarded as insufficient, due to numerous limitations of the techniques (Halliwell, 2012). Methods to measure ROS in-vivo especially live imaging become more and more important and notable progress has been made in probe developing during the past years. Unfortunately only little is known about the roles and impact of ROS and its subsequent oxidative damage in fundamental biological processes, which is because of the difficulty of measuring oxidative damage and the levels of particular ROS in-vivo, together with the uncertainty of interpretation (Murphy et al., 2011). Furthermore, while working with highly fragile cells like embryos complicates the initial situation, as well does the scarcely existing data about ROS measured, specifically in embryos. During embryo culture an "imbalance" between over-abundant oxygen supply and the embryos metabolic needs could be generated through ambient oxygen levels (Tatemoto et al., 2004), which are not even close to physiological in-vivo conditions. Therefore in-vitro settings may be responsible for proportions leading to oxidative stress, damage and loss of normal cell function culminating in apoptosis or cell cycle arrest. CM- $\mathrm{H}_{2}$ DCFDA is a cell-permeable probe that is hydrolyzed intracellularly and as a result retained in the cell. Two-electron oxidation results in the formation of a fluorescent product, which can be monitored by fluorescence-based techniques (Kalyanaraman et al., 2012). The fluorescent intensity of $\mathrm{CM}-\mathrm{H}_{2}$ DCFDA was reported to measure intracellular ROS (Badham et al., 2010), also in mouse preimplantation embryos (Kawamura et al., 2010). Dichlorodihydrofluorescein diacetate is the most widely used probe for detecting intracellular $\mathrm{H}_{2} \mathrm{O}_{2}$ and oxidative stress, which has become popular i. a. through its relatively user-friendly assay (Kalyanaraman et al., 2012). This study reveals a higher mean staining intensity of $\mathrm{CM}-\mathrm{H}_{2}$ DCFDA staining in 
embryos cultured in a $20 \%$ oxygen environment without protein supplementation when compared to embryos cultured in 5\% oxygen conditions with protein supplement (Fig.10). Results correlate with significantly elevated senescence markers in the $20 \%$ oxygen, no protein treatment group. Effects of ROS include but are not limited to higher accumulation rates of oxidation products (Sitte et al., 2001) as well as DNA damage (Bontekoe et al., 2012). Increased measurements of ROS are concomitant with increased DNA-double strand breaks measured via gamma-H2A.X, emphasizing enhanced DNA repair activity adjoining to the side of DNA damage. Despite its detrimental reputation, ROS are important mediators in a range of biological processes, such as cell signaling (Lander, 1997; Murphy et al., 2011) and may be important for embryo development. In addition, interpretation of measured fluorescence intensity remains unclear. First of all, because fluorescence intensity and ROS concentrations cannot assumed to be linear (Wang \& Joseph, 1999), furthermore it is questionable if measurements are that of particular ROS themselves or only of damage that ROS causes (Murphy et al., 2011). Therefore, interpretation of ROS measurements, via fluorescent probes as CM$\mathrm{H}_{2}$ DCFDA, needs to be done carefully. Techniques seem to be flawed, but can be applied to obtain useful information if their limitations and artefacts are considered and understood (Halliwell, 2012), e.g.: Loading cells with low concentrations of the probe is required to avoid cytotoxicity (Halliwell \& Whiteman, 2004); Predication of specifically measured ROS cannot be made but it may be used as a redox indicator probe that responds to changes in intracellular iron signaling or peroxynitrite formation (Kalyanaraman et al., 2012); Knowledge of the chemical reactivity (including the rate constants) of the probes along with their intracellular concentration is essential for any quantitative analyses of products derived from such probes (Zielonka, Hardy, \& Kalyanaraman, 2009). A limit of the study is that we did not perform a control group. For further ROS studies with $\mathrm{CM}-\mathrm{H}_{2}$ DCFDA on embryos a negative control could be achieved by examining unstained cells for autofluorescence in the green emission range or the fluorescence of cell-free mixtures of media adopted to $5 \%$ and $20 \%$ oxygen tension in the incubator. A positive control could for instance be achieved by treating blastocysts with $\mathrm{H}_{2} \mathrm{O}_{2}$. 
Taken together, obtained results emphasize that $20 \%$ oxygen levels in embryo culture could cause oxidative stress via intracellular ROS accumulation in the preimplantation embryo.

Mammalian embryos thriving in-vivo are not exposed to atmospheric oxygen levels. Oxygen tension in the reproductive tract may vary between different mammalian species (mouse, hamster, rabbit, rhesus monkey and humans) as well as in different areas of the reproductive tract (oviductal/ uterine lumen) but only within a range of low oxygen concentrations (1-9\%) (Fischer \& Bavister, 1993). Therefore it is in general questionable why using ambient oxygen levels for embryo culture should be of any feasible advantage. Clearly a certain amount of oxygen is required for cells to develop, but neither anaerobic conditions that can cause an embryo to developmentally arrest, nor atmospheric oxygen conditions that can lead to oxidative stress are desirable, if establishing "in-vivo like" conditions is the goal. While culturing highly vulnerable cells like embryos, a broad range of diminutive factors need to be incorporated and it is incidentally important to create an environment that is able to serve the altering need of a metabolic active, dividing cell. Their permanent changing need for different oxygen supply needs to be satisfactorily covered in every developmental state (Byatt-Smith, Leese, \& Gosden, 1991). By taking above stated into consideration, knowledge of in-vivo oxygen concentrations in the ovaries/ uterus of mammalian species from which embryos are being cultured, is an important determinant prior to embryo culture. Mammal studies showed that oviductal oxygen levels (5-8\%) are higher than in the uterus (3-5\%) (Ufer \& Wang, 2011), where oxygen levels are also cycle dependant and even decrease at the time of implantation (from $\sim 5$ to $3 \%$ ) (Feil et al., 2006). It should be noted that human embryos are approximately four times larger than mouse embryos (Byatt-Smith et al., 1991), consequently data obtained through mouse models should only carefully be applied to human studies (Karagenc, Sertkaya et al., 2004). Measuring the mean oxygen tension in the intrauterine cavity of humans resulted in approximately $12 \%$ air saturation (Ottosen et al., 2006), which is 4 -fold higher than in the uterine cavity of other mammals. This establishes a possible subjection between embryo size and their metabolic needs. Comprising, the question arises if during the process of modern embryo culture (animal studies or in regular IVF laboratories) low oxygen levels should 
be altered. To imitate the different areas of the reproductive tract a cleaving embryo has to pass on its way to final implantation in the endometrium could be the basis for an interesting new experimental design in following studies. In addition to lowering the oxygen tension in the incubator chambers, there are several different ideas for basic approaches to protect embryos from oxidative stress induced damage during in-vitro culture, as for instance adding other antioxidant components to the media (e.g. EDTA) or reducing the insemination duration to avoid oxidative damage caused by sperm cell metabolism as suggested by Catt and Henman in 2000 (Catt \& Henman, 2000). However, a reduction of oxygen tension, which is both more physiological and practical than the addition of either EDTA or ROS-removing enzymes appears to be the optimal solution for the in-vitro culture for murine embryos (Orsi \& Leese, 2001). Reducing the oxygen tension in the incubator chambers $\left(5 \% \quad \mathrm{O}_{2}=24 \%\right.$ air saturation/38mmHg in comparison to $20 \% \mathrm{O}_{2}=95 \%$ air saturation/153mmHg) (Ottosen et al., 2006) and assessing the expression of markers of senescence and reactive oxygen species, in comparison to embryos derived in ambient $\mathrm{O}_{2}$ levels, was decided for in this study. Since other studies showed that blastocyst rates were lower when culturing in $2 \% \mathrm{O}_{2}$ conditions, which can be interpreted as a temperate hypoxic state, oxygen levels were not further decreased than to $5 \%$, which is commonly proven to yield an increased blastocyst rate in comparison to higher oxygen concentrations such as 20\% (Banwell et al., 2007; Feil et al., 2006). Furthermore it is postulated that the cleaving mouse embryo has an optimal oxygen requirement in-vitro approximately equivalent to $5 \%$ oxygen concentrations (Fujitani et al., 1997). All in all several studies showed that lowered incubator $\mathrm{O}_{2}$ tension did not only have a positive effect on the implementation as well as live birth rate in humans (M Meintjes et al., 2009) but also improved embryo development and subsequent pregnancy outcome in animals (Karja et al., 2004; Leoni et al., 2007). This study shows that decreased oxygen tension could have a positive effect on embryo development assuming that decreased markers of cellular senescence are able to represent more viable and healthy blastocysts. Additionally, a possible correlation between oxidative stress and ROS formation in blastocysts could be established. Ambient oxygen might lead to oxidative stress in the highly vulnerable embryo at a critical stage of development. Therefore increasing levels of reactive 
oxygen species might accumulate, eventually intracellular, leading to DNA damage and accumulating oxidation products.

During the study we assessed the blastocyst rate for each replication of embryos used for the experiments. The development for all treatment groups exceeded $75 \%$, but total cell numbers were significantly reduced in the group cultured in $20 \%$ oxygen without protein supplementation in comparison to all other experimental groups (Fig. 8). As already reported in a bovine embryo study, apoptosis rate is higher in in-vitro compared with in-vivo derived embryos (Pomar et al., 2005), suggesting the potentially deleterious effects of a suboptimal culture environment (Knijn et al., 2003). The detection of both apoptotic and arrested cells in bovine blastocysts (Leidenfrost et al., 2011) indicates coexistence of these two cell fates in a single blastocyst, resulting in fewer total cells. The loss of a critical number of cells due to cell stress could therefore lead to embryo lethality. But programmed cell death also plays an important role in normal development, e.g. by regulating the cell number (Kate Hardy, Stark, \& Winston, 2003). Furthermore it is described that in-vivo produced blastocysts showed similar high incidences of cell death in their inner cell mass (ICM) as their in-vitro counterparts, supporting the concept of developmentally programmed forms of ICM cell death (Leidenfrost et al., 2011). Fewer total cells in blastocysts were only observed in the $20 \%$ oxygen without protein group. That leads to the assumption that the addition of protein in the $20 \%$ oxygen group scavenges excessive oxygen radicals. Therefore the threshold necessary to induce ICM cell death may not be reached. It nonetheless seems to results in significant molecular responses that a minimum require resources to repair. This response may ultimately lead to a senescent-like growth arrest. DNA double strand breaks ( $\mathrm{Y}-\mathrm{H} 2 \mathrm{~A} . \mathrm{X})$ are responsible for increasing p21 levels, which subsequently result in checkpoint activation and cell cycle arrest (Fragkos et al., 2009).

Another marker of cellular senescence is increased expression of specific cell cycle and inflammation genes. There are two possible cellular response ways to DNA damage resulting in senescence: The p53-p21 or p16-pRB cell checkpoint pathways (Judith Campisi \& d'Adda di Fagagna, 2007). DNA damage, specifically the one which is associated with $\mathrm{Y}-\mathrm{H} 2 \mathrm{~A} . \mathrm{X}$, initiates the 
p53-p21 signaling pathway at the onset of cellular senescence, whereas unphosphorylated H2A.X leads to degradation of p21 and cell death (Judith Campisi \& d'Adda di Fagagna, 2007; Fragkos et al., 2009). p21 is a cyclindependent kinase inhibitor that is upregulated in dormant mouse blastocysts during delayed implantation (Hamatani, Carter, Sharov, \& Ko, 2004) and causes cell cycle arrest in irradiated embryos (Adiga et al., 2007). In the previous invivo vs in-vitro study conducted by our working group, it was demonstrated that the potent cell cycle inhibitor p21 is upregulated during in-vitro culture in contrast to p16 or IL6 (Meuter et al., 2014). These results provide additional evidence that the senescence response may be active in blastocysts because p21 is a key target of p53-dependent senescence (Brown, Wei, \& Sedivy, 1997). The response to oxidative stress in in-vitro blastocysts may be a premature, stress-induced, senescence-like phenotype, with the primary effect of upregulating p21. Further studies that also take p53 upregulation into consideration are demanded.

In former times, transferring more than one embryo became the standard procedure to maximize the likelihood of pregnancy. The result was a surge of multiple deliveries, a serious complication especially if older women are affected. The number of embryos transferred is a major determinant of the iatrogenic increase in multiple pregnancies and is highly correlated with the likelihood of multiple birth as well as excess perinatal morbidity and mortality (Mansour et al., 2014). More recently, there is an obvious trend towards transfers of fewer embryos with an extreme rise in single and elective single embryo transfers (e/SET) (Andersen et al., 2007) in the U.S. as well as in Europe. This is due to advances in embryo culture conditions which by now allow culturing embryos to the blastocyst stage, thus permitting transfers of fewer embryos (Langley, Marek, Gardner, Doody, \& Doody, 2001). In this study the standard procedure to microscopically select blastocysts prior to uterine transfer was used to select blastocysts prior to the commencement of the assays. Meintjes et al. and Waldenström et al. showed in 2009 that especially blastocysts profit from decreased $\mathrm{O}_{2}$ culture leading to a higher implantation and live birth rate (M Meintjes et al., 2009; Waldenström et al., 2009). Therefore the focus of this study was the impact of different culture systems on blastocysts prior implantation in the uterus cavity. 
Rather than letting the embryo adapt to abnormal conditions in order to survive, culture media must be assimilated to the compounds present in their natural environment, the fallopian tube and uterus cavity. Conditions of imbalance in in-vitro culture conditions need to be eliminated (Biggers, 1998). A culture system should be able to yield a single embryo in superb quality (Lane \& Gardner, 2007). On that account there was a perpetual progression in the composition of a more complex media used to culture embryos in, mainly intending on more closely imitating the contents of human tubal fluid. For that purpose, simple salt solutions were replaced by more complex media containing some sort of protein, macromolecules and growth factors as maternal or fetal cord serum, bovine serum albumin (BSA) or human serum albumin (HSA) (Marius Meintjes et al., 2009). In different studies it was verified that with perpetual development of the early embryo to the advanced stages, there is also a continual change in the metabolic needs. In order to meet the altering requirements of the developing embryo, sequential culture media was developed (Gott et al., 1990; K Hardy et al., 1989; Lane \& Gardner, 2007; Marius Meintjes et al., 2009). As described by Lane and Gardner in 2007, recently a shift took place from individually 'in-house' media preparations to commercially produced media, which was purpose-built for use in clinical IVF applications and established a standard quality. The media could be formulated in a specialized factory aseptically and undergo control inspections according to quality and regulatory actions (Lane \& Gardner, 2007). Therefore, in experiments employed in this study, Global media was used. Global media was developed (according to the manufacturer's statements) resting upon the reports of the successful culture of mouse embryos in potassium simplex optimization medium with amino acids (KSOM-AA) and the results of Klaus Wiemer et al. and Anderson et al. in 2002. They demonstrated that an enhanced KSOM-AA version was able to highly support the development of human embryos to the blastocyst stage (Wiemer et al. 2002; Anderson et al. 2002). Based on this, Global media was onward modified for human use. Even though the manufacturer recommends transferring the embryos to a fresh drop of Global media after 48 hours of culture, in this study Global was used as a single medium from Day 1 onward to reduce the possibility of stress associated with changing the medium composition at Day 3 . On the one hand to avoid 
additional unphysiological movement of the embryos with the micropipetter, on the other hand changing the medium requires extracting the dishes out of the incubators, exposing the $5 \%$ oxygen groups to atmospheric oxygen surroundings, as well as both groups to room temperature. Equally important, the use of a single medium for all phases of embryo culture reduces the requirement for maintenance and quality control of media which reduces the chances for error. It is reported that single media, most notably Global media, support the development of human embryos as well or better than sequential culture media systems do (Don Rieger, 2006).

Protein as a supplement in culture is used as a source of antioxidant. In embryo culture it is attributed a positive impact on the development and viability of embryos (Kruger et al., 1987; Pope, Harrison et al., 1987; Desai et al., 1996; Esfandiari et al., 2005). That is why in this study a $2 \times 2$ factorial design was established which provided half of the embryos in culture with additional Synthetic Serum Substitute (SSS). SSS is a defined mixture of human serum albumin (HSA) enriched with alpha- and beta-globulins for supplementation of IVF culture media and represents a more complex embryo culture medium supplement than HSA alone. In order to mimic the protein content of hitherto used Plasmatein, it contains a $4 \%$ higher globulin content and therefore more closely resembles a real fallopian tube microenvironment leading to higher pregnancy rates and significantly higher implantation rates by (Desai et al., 1996). Also more recent studies verified that the utilization of SSS supplementation during blastocyst culture significantly improved the success rate of a life birth after single blastocysts transfers (Marius Meintjes et al., 2009). Since the late 1990's embryo culture medium was continually improved. Therefore a pertinent question is, whether the additional glycoproteins provided by SSS are still of value for optimal embryo development. In this study applied experiments yield that blastocysts cultured with additional protein supplement along with Global media profited in terms of decreased Senescence-associated beta galactosidase and gamma-H2A.X markers as well as a decreased ROS exhibition in comparison to blastocysts cultured in Global media alone. Interestingly, in combination with elevated oxygen conditions the absence of protein led to a decrease of the blastomere number within the blastocysts. On the contrary, adequate culture systems could maybe be aggravated through the 
addition of protein, if ROS that is possibly necessary for optimal cell development and metabolism are scavenged exceedingly. Obtained results reveal that supplementation of SSS to culture media could be utilized as a second factor contributing to improved culture conditions, in addition to primarily lowered incubator oxygen tension. However, its importance seems to be to a lesser extent than reduced oxygen conditions, indicating that high $\mathrm{O}_{2}$ is the main contributor to in-vitro embryo stress and DNA damage.

In summary, embryos cultured in elevated oxygen conditions have a considerable higher number of cells with extensive DNA repair activity in comparison to those derived in low oxygen conditions. Atmospheric oxygen conditions in culture could be responsible for excessive ROS formation and oxidative stress. Resulting DNA damage as well as consecutive developmental arrest, cell repair or apoptosis could therefore be attributed to the harmful impact excessive ROS might have on embryos. Still benefits and detriments of culturing under ambient or lowered oxygen levels are widely discussed and despite increased embryo culture in a lowered $\mathrm{O}_{2}$ environment (most notably at $5 \%$ ), there are discrepancies in proven advantages of lowered oxygen conditions. Even though in-vitro oxygen levels can be controlled quite easily (Guérin, El Mouatassim, \& Ménézo, 2001) for instance through lowering the oxygen concentration in incubators, it still implies additional effort and expenses (M Meintjes et al., 2009). As a result, human preimplantation embryos also still routinely develop under atmospheric oxygen concentrations in IVF laboratories albeit noted detrimental effects (de Los Santos et al., 2013; P. F. Rinaudo, Giritharan, Talbi, Dobson, \& Schultz, 2006). So far consequences of early embryo stress are difficult to assess. As aforementioned, possibilities could include but are not limited to mitotic arrest (in a senescent-like state) with eventual activation of DNA repair mechanisms or apoptotic cell death. Altered gene expression induced through suboptimal in-vitro culture conditions has to be considered as well (Doherty, Mann, Tremblay, Bartolomei, \& Schultz, 2000; P. Rinaudo \& Schultz, 2004, P. F. Rinaudo et al., 2006). Amongst others, altered gene expression could possibly lead to an increased risk of tumor development in the long term (Freedman \& Folkman, 2005). In contrast, other studies support the relevance of cellular senescence in restricting tumorigenesis in-vivo triggered by DNA damage or activated oncogenes (Judith Campisi, 
2001; Lowe, Cepero, \& Evan, 2004; Schmitt et al., 2002), e.g. by cooperating with p53 in tumor suppression (Chen, Trotman, Shaffer, \& Pandolfi, 2005; Vogelstein, Lane, \& Levine, 2000). In conclusion, oxidative stress in in-vitro cultured blastocysts seems to be a stressor potent enough to induce at least a senescent-like state. Elevated markers of cellular senescence as well as a presumably activated p21-p53 pathway due to suboptimal in-vitro culture are supporting evidence. Situated at the onset of development, embryos could supposedly also enter a transient cell cycle arrest in order to repair accrued celldamage. Therefore, premature alteration in gene expression through DNA damage could possibly be prevented and cells would be able to continue with their development. However, a senescence-like state implies permanent cell cycle arrest. An interesting approach for a different study design could be the health assessment of people who were received via IVF. A study could assess the health condition of the parents, IVF procedure conditions in that particular case, the health condition of the proband e.g. every decade, including tumor risk factors (to assess eventual altered gene expression). This investigation should be compared to individuals received via normal intercourse, at the same age, gender and maturing in the same geographic area as the probands. Despite the results of other studies investigating implementation and/ or live birth rates as well as perinatal outcome e.g. birthweight, the effect of in-vitro culture on embryo health remains an important area of investigation as questions about potential adverse effects of culture continue to be raised (Dumoulin et al., 2010; Nelissen et al., 2012; Kleijkers et al., 2014). Combined with results obtained from this study, it can be hypothesized that embryos derived in a $5 \% \mathrm{O}_{2}$ environment with protein supplementation are maybe able to yield a better implantation, pregnancy and live birth rate outcome than those derived in elevated oxygen conditions. Extending this study design by implanting blastocysts back in the uterus cavity of the mice and investigating implantation as well as live birth rate could be of great interest in subsequent studies to verify the potential of used markers of cellular senescence. These markers could possibly be indicative of more optimal quality embryos. In general, in an area characterized by costly, vital and psychological importance like reproductive medicine, it should be the primary goal to achieve the highest live birth rate possible and to ensure appropriate gene expression. Despite 
common usage of reduced-oxygen culture in bovine embryo production and improved live birth rates for human IVF (Kovacic, Sajko, \& Vlaisavljević, 2010; M Meintjes et al., 2009), many clinical IVF laboratories continue to use $20 \%$ oxygen (Bontekoe et al., 2012). Therefore stress-induced premature senescence may occur in human blastocysts, with downstream effects on their development (Meuter, Rogmann et al., 2014). Results obtained from this study show that differences in culture conditions could have an immense effect on the developing embryo and further support that lowered $\mathrm{O}_{2}$ tension has a presumably positive effect on preimplantation embryos. 


\section{Summary of Discussion}

Taken together, markers of cellular senescence (SA- $\beta$-galactosidase and $\gamma$ $\mathrm{H} 2 \mathrm{~A} . \mathrm{X}$ ) as well as $\mathrm{CM}-\mathrm{H}_{2}$ DCFDA fluorescence (associated with intracellular ROS levels), are elevated in murine blastocysts cultured in $20 \%$ oxygen versus $5 \%$ oxygen in-vitro conditions and indicate that a senescence-like state may be induced through oxidative stress and suboptimal culture conditions. Embryos cultured in elevated oxygen conditions have a considerable higher number of cells with extensive DNA repair activity in comparison to those derived in low oxygen conditions. Atmospheric oxygen conditions in culture could be responsible for excessive ROS formation and oxidative stress. Resulting DNA damage as well as consecutive developmental arrest, cell repair or apoptosis could therefore be attributed to the harmful impact excessive ROS might have on embryos. Culture in 5\% oxygen reduced markers to levels similar to those seen in in-vivo embryos, illustrating a culture condition which seems very well qualified for embryo culture. The fate of DNA-damaged cells in blastocysts is unknown, but the possibilities include repair with transient cell cycle arrest, senescence with complete cell cycle arrest, or apoptotic cell death. If accruing costs during the IVF process can be reduced due to the availability of higher quality embryos and a potentially positive effect on resulting live birth rates can be achieved, a substantial progress could be obtained in IVF and the field of reproductive medicine. 


\section{$8 \quad$ Table of figures}

Figure 1 Chart: Post collection embryos used for Experiment 1 (2x2 factorial design)

Figure 2 Chart: Post collection embryos used for Experiment 2.

Figure 3 Images: Murine blastocysts developed in-vitro in different culture conditions, after staining for senescence-associated (SA-) $\beta$ galactosidase.

Figure 4 Graph: Percentage of blastocysts positive for senescenceassociated (SA-) $\beta$-galactosidase activity .....

Figure 5 Image: In-vitro blastocysts stained with DAPI (blue) and overlaid with $\mathrm{y}$-H2A.X (green).

Figure 6 Image: from Figure 5 in the artificial pseudo color palette rainbow display.

Figure 7 Graph: Percentage of cells in each blastocyst positive for $\mathrm{Y}-\mathrm{H} 2 \mathrm{~A} . \mathrm{X} \ldots 28$

Figure 8 Graph: Number of cells per blastocyst for each oxygen and protein supplementation group

Figure 9 Image: ROS detection with $\mathrm{CM}-\mathrm{H}_{2}$ DCFDA staining in blastocysts .....31

Figure 10 Graph: Percentage of mean staining intensity of blastocysts positive for $\mathrm{CM}-\mathrm{H}_{2}$ DCFDA activity 


\section{Bibliography}

Adiga, S. K., Toyoshima, M., Shiraishi, K., Shimura, T., Takeda, J., Taga, M., ... Niwa, O. (2007). p21 provides stage specific DNA damage control to preimplantation embryos. Oncogene, 26(42), 6141-6149.

doi:10.1038/sj.onc.1210444

Andersen, a N., Goossens, V., Gianaroli, L., Felberbaum, R., de Mouzon, J., \& Nygren, K. G. (2007). Assisted reproductive technology in Europe, 2003. Results generated from European registers by ESHRE. Human Reproduction (Oxford, England), 22(6), 1513-25.

doi:10.1093/humrep/dem053

Badham, H. J., Renaud, S. J., Wan, J., \& Winn, L. M. (2010). Benzene-initiated oxidative stress: Effects on embryonic signaling pathways. ChemicoBiological Interactions, 184(1-2), 218-21. doi:10.1016/j.cbi.2009.11.005

Banwell, K. M., Lane, M., Russell, D. L., Kind, K. L., \& Thompson, J. G. (2007). Oxygen concentration during mouse oocyte in vitro maturation affects embryo and fetal development. Human Reproduction, 22(10), 2768-2775. doi:10.1093/humrep/dem203

Bedaiwy, M. a, Falcone, T., Mohamed, M. S., Aleem, A. a N., Sharma, R. K., Worley, S. E., ... Agarwal, A. (2004). Differential growth of human embryos in vitro: role of reactive oxygen species. Fertility and Sterility, 82(3), 593600. doi:10.1016/j.fertnstert.2004.02.121

Betts, D. H., \& King, W. A. (2001a). Genetic regulation of embryo death and senescence. Theriogenology, 55(1), 171-191. Retrieved from http://www.ncbi.nlm.nih.gov/pubmed/11198081

Betts, D. H., \& King, W. A. (2001b). GENETIC REGULATION OF EMBRYO DEATH AND SENESCENCE D.H. Betts" and W.A. King Department of Biomedical Sciences, Ontario Veterinary College University of Guelph, Guelph, Ontario, Canada, NIG 2WI. Inflammation, (00), 171-191.

Betts, D. H., \& Madan, P. (2008). Permanent embryo arrest: molecular and cellular concepts. Molecular Human Reproduction, 14(8), 445-453. doi:10.1093/molehr/gan035

Biggers, J. D. (1998). Reflections on the culture of the preimplantation embryo. The International Journal of Developmental Biology, 42(7), 879-84. Retrieved from http://www.ncbi.nlm.nih.gov/pubmed/9853817

Bontekoe, S., Mantikou, E., van Wely, M., Seshadri, S., Repping, S., \& Mastenbroek, S. (2012). Low oxygen concentrations for embryo culture in assisted reproductive technologies. The Cochrane Database of Systematic Reviews, 7(7), CD008950. doi:10.1002/14651858.CD008950.pub2 
Brown, J. P., Wei, W., \& Sedivy, J. M. (1997). Bypass of senescence after disruption of p21CIP1/WAF1 gene in normal diploid human fibroblasts. Science (New York, N.Y.), 277(5327), 831-834. doi:10.1126/science.277.5327.831

Byatt-Smith, J. G., Leese, H. J., \& Gosden, R. G. (1991). An investigation by mathematical modelling of whether mouse and human preimplantation embryos in static culture can satisfy their demands for oxygen by diffusion. Human Reproduction (Oxford, England), 6(1), 52-7. Retrieved from http://www.ncbi.nlm.nih.gov/pubmed/1874957

Campisi, J. (2001). Cellular senescence as a tumor-suppressor mechanism. Trends in Cell Biology, 11(11), S27-S31. doi:10.1016/S09628924(01)02151-1

Campisi, J., \& d'Adda di Fagagna, F. (2007). Cellular senescence: when bad things happen to good cells. Nature Reviews. Molecular Cell Biology, 8(9), 729-740. doi:10.1038/nrm2233

Campisi, J., \& d'Adda di Fagagna, F. (2007). Cellular senescence: when bad things happen to good cells. Nature Reviews. Molecular Cell Biology, 8(9), 729-40. doi:10.1038/nrm2233

Catt, J. W., \& Henman, M. (2000). Toxic effects of oxygen on human embryo development. Human, 15(Suppl.2), 199-206.

Chen, Z., Trotman, L. C., Shaffer, D., \& Pandolfi, P. P. (2005). Crucial role of p53-dependent cellular senescence in suppression of Pten-deficient tumorigenesis. Nature, 436(7051), 725-730. doi:10.1111/j.13652958.2010.07165.x.Characterization

Crosier, a E., Farin, P. W., Dykstra, M. J., Alexander, J. E., \& Farin, C. E. (2001). Ultrastructural morphometry of bovine blastocysts produced in vivo or in vitro. Biology of Reproduction, 64(5), 1375-85. Retrieved from http://www.ncbi.nlm.nih.gov/pubmed/11319141

d'Adda di Fagagna, F. (2008). Living on a break: cellular senescence as a DNAdamage response. Nature Reviews. Cancer, 8(7), 512-522.

doi:10.1038/nrc2440

De Los Santos, M. J., Gámiz, P., Albert, C., Galán, A., Viloria, T., Pérez, S., ... Remohï, J. (2013). Reduced oxygen tension improves embryo quality but not clinical pregnancy rates: a randomized clinical study into ovum donation cycles. Fertility and Sterility, 100(2), 402-7.

doi:10.1016/j.fertnstert.2013.03.044

Debacq-Chainiaux, F., Borlon, C., Pascal, T., Royer, V., Eliaers, F., Ninane, N., ... Toussaint, O. (2005). Repeated exposure of human skin fibroblasts to UVB at subcytotoxic level triggers premature senescence through the TGFbeta1 signaling pathway. Journal of Cell Science, 118(Pt 4), 743-58.

doi:10.1242/jcs.01651 
Debacq-Chainiaux, F., Erusalimsky, J. D., Campisi, J., \& Toussaint, O. (2009). Protocols to detect senescence-associated beta-galactosidase (SAbetagal) activity, a biomarker of senescent cells in culture and in vivo. Nature Protocols, 4(12), 1798-806. doi:10.1038/nprot.2009.191

Desai, N. N., Sheean, L. a, Martin, D., Gindlesperger, V., Austin, C. M., Lisbonna, H., ... Goldfarb, J. M. (1996). Clinical experience with synthetic serum substitute as a protein supplement in IVF culture media: a retrospective study. Journal of Assisted Reproduction and Genetics, 13(1), 23-31. Retrieved from http://www.ncbi.nlm.nih.gov/pubmed/8825163

Diedrich, K. (2007). Gynäkologie und Geburtshilfe, 2.Auflage (2. ed.). Springer.

Dimri, G. P., Lee, X., Basile, G., Acosta, M., Scott, G., Roskelley, C., ... et al. (1995). A biomarker that identifies senescent human cells in culture and in aging skin in vivo. Proceedings of the National Academy of Sciences of the United States of America, 92(20), 9363-9367. Retrieved from http://www.ncbi.nlm.nih.gov/pubmed/7568133

Doherty, a S., Mann, M. R., Tremblay, K. D., Bartolomei, M. S., \& Schultz, R. M. (2000). Differential effects of culture on imprinted $\mathrm{H} 19$ expression in the preimplantation mouse embryo. Biology of Reproduction, 62(6), 15261535. doi:10.1095/biolreprod62.6.1526

Dumont, P., Burton, M., Chen, Q. M., \& Toussaint, O. (2000). INDUCTION OF REPLICATIVE SENESCENCE BIOMARKERS BY. Free Radical Biology \& Medicine, 28(3), 361-373.

Dumoulin, J. C., Land, J. a., Van Montfoort, A. P., Nelissen, E. C., Coonen, E., Derhaag, J. G., ... Evers, J. L. (2010). Effect of in vitro culture of human embryos on birthweight of newborns. Human Reproduction, 25(3), 605612. doi:10.1093/humrep/dep456

Esfandiari, N., Falcone, T., Agarwal, A., Attaran, M., Nelson, D. R., \& Sharma, R. K. (2005). Protein supplementation and the incidence of apoptosis and oxidative stress in mouse embryos. Obstetrics and Gynecology, 105(3), 653-660. doi:10.1097/01.AOG.0000152384.91385.71

Farquhar, C., Jr, R., Brown, J., Wldm, N., \& Marjoribanks, J. (2013). Assisted reproductive technology : an overview of Cochrane Reviews (Review ), (8).

Favetta, L. a, St John, E. J., King, W. A., \& Betts, D. H. (2007). High levels of p66shc and intracellular ROS in permanently arrested early embryos. Free Radical Biology \& Medicine, 42(8), 1201-10. doi:10.1016/j.freeradbiomed.2007.01.018

Favetta, L. A., Madan, P., Mastromonaco, G. F., St John, E. J., King, W. A., \& Betts, D. H. (2007). The oxidative stress adaptor p66Shc is required for permanent embryo arrest in vitro. BMC Developmental Biology, 7, 132. doi:10.1186/1471-213X-7-132 
Favetta, L. A., Robert, C., St John, E. J., Betts, D. H., \& King, W. A. (2004). p66shc, but not p53, is involved in early arrest of in vitro-produced bovine embryos. Molecular Human Reproduction, 10(6), 383-392.

doi:10.1093/molehr/gah057

Feil, D., Lane, M., Roberts, C. T., Kelley, R. L., Edwards, L. J., Thompson, J. G., \& Kind, K. L. (2006). Effect of culturing mouse embryos under different oxygen concentrations on subsequent fetal and placental development. The Journal of Physiology, 572(Pt 1), 87-96. doi:10.1113/jphysiol.2005.102681

Ferraretti, a P., Goossens, V., Kupka, M., Bhattacharya, S., de Mouzon, J., Castilla, J. a, ... Nyboe Andersen, a. (2013). Assisted reproductive technology in Europe, 2009: results generated from European registers by ESHRE. Human Reproduction (Oxford, England), 28(9), 2318-31. doi:10.1093/humrep/det278

Fischer, B., \& Bavister, B. D. (1993). Oxygen tension in the oviduct and uterus of rhesus monkeys, hamsters and rabbits. Journal of Reproduction and Fertility, 99(2), 673-9. Retrieved from http://www.ncbi.nlm.nih.gov/pubmed/8107053

Fragkos, M., Jurvansuu, J., \& Beard, P. (2009). H2AX is required for cell cycle arrest via the p53/p21 pathway. Molecular and Cellular Biology, 29(10), 2828-2840. doi:10.1128/MCB.01830-08

Freedman, D. A., \& Folkman, J. (2005). CDK2 translational down-regulation during endothelial senescence. Experimental Cell Research, 307(1), 11830. doi:10.1016/j.yexcr.2005.03.025

Frippiat, C., Chen, Q. M., Zdanov, S., Magalhaes, J. P., Remacle, J., \& Toussaint, O. (2001). Subcytotoxic H2O2 stress triggers a release of transforming growth factor-beta 1, which induces biomarkers of cellular senescence of human diploid fibroblasts. The Journal of Biological Chemistry, 276(4), 2531-7. doi:10.1074/jbc.M006809200

Fujitani, Y., Kasai, K., Ohtani, S., Nishimura, K., Yamada, M., \& Utsumi, K. (1997). vitro-produced bovine embryos. The online version of this article, along with updated information and services, is located on the World Wide Web at: Effect of Oxygen Concentration and Free Radicals on In Vitro Development of In Vitro-Produced Bovine E, 483-489.

Gott, a L., Hardy, K., Winston, R. M., \& Leese, H. J. (1990). Non-invasive measurement of pyruvate and glucose uptake and lactate production by single human preimplantation embryos. Human Reproduction (Oxford, England), 5(1), 104-8. Retrieved from http://www.ncbi.nlm.nih.gov/pubmed/2324239

Guérin, P., El Mouatassim, S., \& Ménézo, Y. (2001). Oxidative stress and protection against reactive oxygen species in the pre-implantation embryo 
and its surroundings. Human Reproduction Update, 7(2), 175-89. Retrieved from http://www.ncbi.nlm.nih.gov/pubmed/11284661

Halliwell, B. (2012). Free radicals and antioxidants: updating a personal view. Nutrition Reviews, 70(5), 257-65. doi:10.1111/j.1753-4887.2012.00476.x

Halliwell, B., \& Whiteman, M. (2004). Measuring reactive species and oxidative damage in vivo and in cell culture: how should you do it and what do the results mean? British Journal of Pharmacology, 142(2), 231-255. doi:10.1038/sj.bjp.0705776

Hamatani, T., Carter, M. G., Sharov, a a, \& Ko, M. S. (2004). Dynamics of global gene expression changes during mouse preimplantation development. Dev Cell, 6(1), 117-131. doi:S1534580703003733 [pii]

Hardy, K. (1997). Cell death in the mammalian blastocyst. Molecular Human Reproduction, 3(10), 919-925.

Hardy, K., Hooper, M. a, Handyside, a H., Rutherford, a J., Winston, R. M., \& Leese, H. J. (1989). Non-invasive measurement of glucose and pyruvate uptake by individual human oocytes and preimplantation embryos. Human Reproduction (Oxford, England), 4(2), 188-91. Retrieved from http://www.ncbi.nlm.nih.gov/pubmed/2918073

Hardy, K., Stark, J., \& Winston, R. M. L. (2003). Maintenance of the inner cell mass in human blastocysts from fragmented embryos. Biology of Reproduction, 68(4), 1165-1169. doi:10.1095/biolreprod.102.010090

Harman, D. (1956). Aging: a theory based on free radical and radiation chemistry. Journal of Gerontology, 11(3), 298-300. Retrieved from http://www.ncbi.nlm.nih.gov/pubmed/13332224

Harvey, a J. (2007). The role of oxygen in ruminant preimplantation embryo development and metabolism. Animal Reproduction Science, 98(1-2), 11328. doi:10.1016/j.anireprosci.2006.10.008

Harvey, M. B., Arcellana-Panlilio, M. Y., Zhang, X., Schultz, G. a, \& Watson, a J. (1995). Expression of genes encoding antioxidant enzymes in preimplantation mouse and cow embryos and primary bovine oviduct cultures employed for embryo coculture. Biology of Reproduction, 53(3), 532-40. Retrieved from http://www.ncbi.nlm.nih.gov/pubmed/7578676

Hayflick, L., \& Moorhead, P. S. (1961). The serial cultivation of human diploid cell strains. Experimental Cell Research, 25, 585-621. doi:10.1016/00144827(61)90192-6

Herbig, U., Jobling, W. A., Chen, B. P. C., Chen, D. J., \& Sedivy, J. M. (2004). Telomere Shortening Triggers Senescence of Human Cells through a Pathway Involving ATM, p53, and p21CIP1, but Not p16INK4a. Molecular Cell, 14, 501-513. 
Ishii, N., Oohira, T., Oshima, A., Sakuraba, H., Endo, F., Matsuda, I., ... Suzuki, Y. (1995). Clinical and molecular analysis of a Japanese boy with Morquio B disease. Clinical Genetics, 48, 103-108.

Itahana, K., Campisi, J., \& Dimri, G. P. (2007). Methods to detect biomarkers of cellular senescence: the senescence-associated beta-galactosidase assay. Methods in Molecular Biology, 371, 21-31. Retrieved from http://www.ncbi.nlm.nih.gov/pubmed/17634571

Jansen, R. P. S. (2003). The effect of female age on the likelihood of a live birth from one in-vitro fertilisation treatment. The Medical Journal of Australia, 178(6), 258-61. Retrieved from http://www.ncbi.nlm.nih.gov/pubmed/12633481

Jurisicova, A., \& Acton, B. M. (2004). Deadly decisions: the role of genes regulating programmed cell death in human preimplantation embryo development. Reproduction (Cambridge, England), 128(3), 281-91. doi:10.1530/rep.1.00241

Kalyanaraman, B., Darley-Usmar, V., Davies, K. J. A., Dennery, P. A., Forman, H. J., Grisham, M. B., ... Ischiropoulos, H. (2012). Measuring reactive oxygen and nitrogen species with fluorescent probes: challenges and limitations. Free Radical Biology \& Medicine, 52(1), 1-6.

doi:10.1016/j.freeradbiomed.2011.09.030

Karagenc, L., Sertkaya, Z., Ciray, N., Ulug, U., \& Bahceci, M. (2004). Impact of oxygen concentration on embryonic development of mouse zygotes. Reproductive Biomedicine Online, 9(4), 409-417. Retrieved from http://www.ncbi.nlm.nih.gov/pubmed/15511341

Karja, N. W. K., Wongsrikeao, P., Murakami, M., Agung, B., Fahrudin, M., Nagai, T., \& Otoi, T. (2004). Effects of oxygen tension on the development and quality of porcine in vitro fertilized embryos. Theriogenology, 62(9), 1585-95. doi:10.1016/j.theriogenology.2004.03.012

Kawamura, Y., Uchijima, Y., Horike, N., Tonami, K., Nishiyama, K., Amano, T., ... Kurihara, H. (2010). Sirt3 protects in vitro - fertilized mouse preimplantation embryos against oxidative stress - induced p53-mediated developmental arrest, 120(8). doi:10.1172/JCI42020DS1

Kind, K. L., Collett, R. a., Harvey, A. J., \& Thompson, J. G. (2005). Oxygenregulated expression of GLUT-1, GLUT-3, and VEGF in the mouse blastocyst. Molecular Reproduction and Development, 70(1), 37-44. doi:10.1002/mrd.20183

Kleijkers, S. H. M., Van Montfoort, A. P. a, Smits, L. J. M., Viechtbauer, W., Roseboom, T. J., Nelissen, E. C. M., ... Dumoulin, J. C. M. (2014). IVF culture medium affects post-natal weight in humans during the first 2 years of life. Human Reproduction, 29(4), 661-669. doi:10.1093/humrep/deu025 
Knijn, H. M., Gjørret, J. O., Vos, P. L. a M., Hendriksen, P. J. M., van der Weijden, B. C., Maddox-Hyttel, P., \& Dieleman, S. J. (2003). Consequences of in vivo development and subsequent culture on apoptosis, cell number, and blastocyst formation in bovine embryos. Biology of Reproduction, 69(4), 1371-1378. doi:10.1095/biolreprod.103.017251

Kovacic, B., Sajko, M. C., \& Vlaisavljević, V. (2010). A prospective, randomized trial on the effect of atmospheric versus reduced oxygen concentration on the outcome of intracytoplasmic sperm injection cycles. Fertility and Sterility, 94(2), 511-9. doi:10.1016/j.fertnstert.2009.03.077

Kruger, T. F., Stander, F. S. H., Smith, K., Van der Merwe, J. P., \& Lombard, C. J. (1987). The effect of serum supplementation on the cleavage of human embryos. Journal of In Vitro Fertilization and Embryo Transfer, 4(1), 10-12. doi:10.1007/BF01555428

Kupka, M. S., Ferraretti, A. P., de Mouzon, J., \& Goossens, V. (2014). Assisted reproductive technology in Europe, 2010. Results generated from European registers by ESHRE. Hum. Reprod., 29(10), 2099-2113. doi:10.1093/humrep/des255

Kurz, D. J., Decary, S., Hong, Y., \& Erusalimsky, J. D. (2000). Senescenceassociated (beta)-galactosidase reflects an increase in lysosomal mass during replicative ageing of human endothelial cells. Journal of Cell Science, 113 ( Pt 2, 3613-3622. Retrieved from http://www.ncbi.nlm.nih.gov/pubmed/11017877

Lander, H. M. (1997). An essential role for free radicals and derived species in signal transduction. The FASEB Journal : Official Publication of the Federation of American Societies for Experimental Biology, 11(2), 118124.

Lane, M., \& Gardner, D. K. (2007). Embryo culture medium: which is the best? Best Practice \& Research. Clinical Obstetrics \& Gynaecology, 21(1), 83100. doi:10.1016/j.bpobgyn.2006.09.009

Langley, M. T., Marek, D. M., Gardner, D. K., Doody, K. M., \& Doody, K. J. (2001). Extended embryo culture in human assisted reproduction treatments. Human Reproduction (Oxford, England), 16(5), 902-8. Retrieved from http://www.ncbi.nlm.nih.gov/pubmed/11331636

Lawless, C., Wang, C., Jurk, D., Merz, A., Zglinicki, T. Von, \& Passos, J. F. (2010). Quantitative assessment of markers for cell senescence.

Experimental Gerontology, 45(10), 772-8. doi:10.1016/j.exger.2010.01.018

Lee, B. Y., Han, J. A., Im, J. S., Morrone, A., Johung, K., Goodwin, E. C., ... Hwang, E. S. (2006). Senescence-associated beta-galactosidase is lysosomal beta-galactosidase. Aging Cell, 5(2), 187-195.

doi:10.1111/j.1474-9726.2006.00199.x 
Leidenfrost, S., Boelhauve, M., Reichenbach, M., Gungor, T., Reichenbach, H. D., Sinowatz, F., ... Habermann, F. A. (2011). Cell arrest and cell death in mammalian preimplantation development: lessons from the bovine model. PloS One, 6(7), e22121. doi:10.1371/journal.pone.0022121

Leoni, G. G., Rosati, I., Succu, S., Bogliolo, L., Bebbere, D., Berlinguer, F., ... Naitana, S. (2007). A low oxygen atmosphere during IVF accelerates the kinetic of formation of in vitro produced ovine blastocysts. Reproduction in Domestic Animals = Zuchthygiene, 42(3), 299-304. doi:10.1111/j.14390531.2006.00783.x

$\mathrm{Li}, \mathrm{S}$. (2003). Modification of the ionizing radiation response in living cells by an scFv against the DNA-dependent protein kinase. Nucleic Acids Research, 31(20), 5848-5857. doi:10.1093/nar/gkg775

Liton, P. B., Lin, Y., Gonzalez, P., \& Epstein, D. L. (2009). Potential role of lysosomal dysfunction in the pathogenesis of primary open angle glaucoma. Autophagy, 5(1), 122-124. doi:10.1167/iovs.08-1915.Liton

Lowe, S. W., Cepero, E., \& Evan, G. (2004). Intrinsic tumour suppression. Nature, 432(7015), 307-315. doi:10.1038/nature03098

Mah, L.-J., El-Osta, a, \& Karagiannis, T. C. (2010). gammaH2AX: a sensitive molecular marker of DNA damage and repair. Leukemia : Official Journal of the Leukemia Society of America, Leukemia Research Fund, U.K, 24(4), 679-686. doi:10.1038/leu.2010.6

Mansour, R., Ishihara, O., Adamson, G. D., Dyer, S., de Mouzon, J., Nygren, K. G., ... Zegers-Hochschild, F. (2014). International Committee for Monitoring Assisted Reproductive Technologies (ICMART) world report: Assisted reproductive technology 2006. Human Reproduction, 29(7), 1535-1551. doi:10.1093/humrep/det036

Meintjes, M., Chantilis, S. J., Douglas, J. D., Rodriguez, A. J., Guerami, A. R., Bookout, D. M., ... Madden, J. D. (2009). A controlled randomized trial evaluating the effect of lowered incubator oxygen tension on live births in a predominantly blastocyst transfer program. Human Reproduction, 24(2), 300-307. doi:10.1093/humrep/den368

Meintjes, M., Chantilis, S. J., Ward, D. C., Douglas, J. D., Rodriguez, A. J., Guerami, A. R., ... Madden, J. D. (2009). A randomized controlled study of human serum albumin and serum substitute supplement as protein supplements for IVF culture and the effect on live birth rates. Human Reproduction (Oxford, England), 24(4), 782-9. doi:10.1093/humrep/den396

Meuter, A., Rogmann, L.-M., Winterhoff, B. J., Tchkonia, T., Kirkland, J. L., \& Morbeck, D. E. (2014). Markers of cellular senescence are elevated in murine blastocysts cultured in vitro: molecular consequences of culture in atmospheric oxygen. Journal of Assisted Reproduction and Genetics. doi:10.1007/s10815-014-0299-8 
Mu, X. F., Jin, X. L., Farnham, M. M. J., Li, Y., \& O’Neill, C. (2011). DNA Damage-Sensing Kinases Mediate the Mouse 2-Cell Embryo's Response to Genotoxic Stress. Biology of Reproduction, 85(3), 524-535. doi:10.1095/biolreprod.110.089334

Murphy, M. P., Holmgren, A., Larsson, N.-G., Halliwell, B., Chang, C. J., Kalyanaraman, B., ... Winterbourn, C. C. (2011). Unraveling the biological roles of reactive oxygen species. Cell Metabolism, 13(4), 361-6. doi:10.1016/j.cmet.2011.03.010

Nasr-Esfahani, M. M., \& Johnson, M. H. (1991). The origin of reactive oxygen species in mouse embryos cultured in vitro. Development (Cambridge, England), 113(2), 551-60. Retrieved from http://www.ncbi.nlm.nih.gov/pubmed/1664322

Nelissen, E. C., Van Montfoort, A. P., Coonen, E., Derhaag, J. G., Geraedts, J. P., Smits, L. J., ... Dumoulin, J. C. (2012). Further evidence that culture media affect perinatal outcome: Findings after transfer of fresh and cryopreserved embryos. Human Reproduction, 27(7), 1966-1976. doi:10.1093/humrep/des145

Nygren, K. G., \& Andersen, a N. (2001). Assisted reproductive technology in Europe, 1998. Results generated from European registers by ESHRE. European Society of Human Reproduction and Embryology. Human Reproduction (Oxford, England), 16(11), 2459-2471.

Orsi, N., \& Leese, H. (2001). Protection against reactive oxygen species during mouse preimplantation embryo development: role of EDTA, oxygen tension, catalase, superoxide dismutase and. Molecular Reproduction and Development, 53(December 2000), 44-53. Retrieved from http://onlinelibrary.wiley.com/doi/10.1002/mrd.1006/abstract

Ottosen, L. D., Hindkaer, J., Husth, M., Petersen, D. E., Kirk, J., \& Ingerslev, H. J. (2006). Observations on intrauterine oxygen tension measured by fibreoptic microsensors. Reproductive Biomedicine Online, 13(3), 380-385. Retrieved from http://www.ncbi.nlm.nih.gov/pubmed/16984770

Passos, J. F., Saretzki, G., \& von Zglinicki, T. (2007). DNA damage in telomeres and mitochondria during cellular senescence: is there a connection? Nucleic Acids Research, 35(22), 7505-13. doi:10.1093/nar/gkm893

Passos, J. F., Von Zglinicki, T., \& Kirkwood, T. B. L. (2007). Mitochondria and ageing: Winning and losing in the numbers game. BioEssays, 29(9), 908917. doi:10.1002/bies.20634

Plante, L., Betteridge, K. J., \& King, W. A. (1989). Development and viability of bovine embryos derived from, (Icm).

Pomar, F. J. R., Teerds, K. J., Kidson, A., Colenbrander, B., Tharasanit, T., Aguilar, B., \& Roelen, B. A. J. (2005). Differences in the incidence of 
apoptosis between in vivo and in vitro produced blastocysts of farm animal species: a comparative study. Theriogenology, 63(8), 2254-68.

doi:10.1016/j.theriogenology.2004.10.015

Pope, A. K., Harrison, K. L., Wilson, L. M., \& Breen, T. M. (1987). UltroSer G as a Serum Substitute in Embeyo Culture Medium. Journal of In Vitro Fertilization and Embryo Transfer, 4(5), 97.

Rieger, D. (2006). Lifeglobal clinical studies.

Rieger, D., Loskutoff, N. M., \& Betteridge, K. J. (1992). Developmentally related changes in the metabolism of glucose and glutamine by cattle embryos produced and co-cultured in vitro. Journal of Reproduction and Fertility, 95(2), 585-95. Retrieved from http://www.ncbi.nlm.nih.gov/pubmed/1518013

Rinaudo, P. F., Giritharan, G., Talbi, S., Dobson, A. T., \& Schultz, R. M. (2006). Effects of oxygen tension on gene expression in preimplantation mouse embryos. Fertility and Sterility, 86(4 Suppl), 1252-65, 1265 e1-36. doi:10.1016/j.fertnstert.2006.05.017

Rinaudo, P., \& Schultz, R. M. (2004). Effects of embryo culture on global pattern of gene expression in preimplantation mouse embryos. Reproduction, 128(3), 301-311. doi:10.1530/rep.1.00297

Rodier, F., \& Campisi, J. (2011). Four faces of cellular senescence. The Journal of Cell Biology, 192(4), 547-556. doi:10.1083/jcb.201009094

Schmitt, C. A., Fridman, J. S., Yang, M., Lee, S., Baranov, E., Hoffman, R. M., \& Lowe, S. W. (2002). A Senescence Program Controlled by p53 and p16INK4a Contributes to the Outcome of Cancer Therapy. Cell, 109(3), 335-346. doi:10.1016/S0092-8674(02)00734-1

Schorge, J. O., Schaffer, J. I., Halvorson, L. M., Hoffman, B. L., Bradshaw, K. D., \& Cunningham, F. G. (2008). Williams Gynecology. The McGraw-Hill Companies.

Severino, J., Allen, R. G., Balin, S., Balin, A., \& Cristofalo, V. J. (2000). Is betagalactosidase staining a marker of senescence in vitro and in vivo? Experimental Cell Research, 257(1), 162-171. doi:10.1006/excr.2000.4875

Sitte, N., Merker, K., Grune, T., \& Von Zglinicki, T. (2001). Lipofuscin accumulation in proliferating fibroblasts in vitro: An indicator of oxidative stress. Experimental Gerontology, 36(3), 475-486. doi:10.1016/S05315565(00)00253-9

Smith, J. R., \& Pereira-Smith, O. M. (1996). Replicative Implications Tumor and Senescence: Aging for in Vivo Suppression. Science, 273(5271), 63-67. 
Stewart, G. S., Wang, B., Bignell, C. R., Taylor, a M. R., \& Elledge, S. J. (2003). MDC1 is a mediator of the mammalian DNA damage checkpoint. Nature, 421(6926), 961-6. doi:10.1038/nature01446

Tarin, J. J. (1996). Potential effects of age-associated oxidative stress on mammalian oocytes / embryos. Molecular Human Reproduction, 2(10), 717-724.

Tatemoto, H., Muto, N., Sunagawa, I., Shinjo, A., \& Nakada, T. (2004). Protection of porcine oocytes against cell damage caused by oxidative stress during in vitro maturation: role of superoxide dismutase activity in porcine follicular fluid. Biology of Reproduction, 71(4), 1150-7. doi:10.1095/biolreprod.104.029264

Thomas, M. R., Sparks, A. E., Ryan, G. L., \& Van Voorhis, B. J. (2010). Clinical predictors of human blastocyst formation and pregnancy after extended embryo culture and transfer. Fertility and Sterility, 94(2), 543-548. doi:10.1016/j.fertnstert.2009.03.051

Ufer, C., \& Wang, C. C. (2011). The Roles of Glutathione Peroxidases during Embryo Development. Frontiers in Molecular Neuroscience, 4(July), 12. doi:10.3389/fnmol.2011.00012

Vogelstein, B., Lane, D., \& Levine, a J. (2000). Surfing the p53 network. Nature, 408(6810), 307-310. doi:10.1038/35042675

Von Zglinicki, T. (2000). Role of oxidative stress in telomere length regulation and replicative senescence. Annals of the New York Academy of Sciences, 908, 99-110. Retrieved from http://www.ncbi.nlm.nih.gov/pubmed/10911951

Von Zglinicki, T., Saretzki, G., Ladhoff, J., d'Adda di Fagagna, F., \& Jackson, S. P. (2005). Human cell senescence as a DNA damage response.

Mechanisms of Ageing and Development, 126(1), 111-7. doi:10.1016/j.mad.2004.09.034

Waldenström, U., Engström, A.-B., Hellberg, D., \& Nilsson, S. (2009). Lowoxygen compared with high-oxygen atmosphere in blastocyst culture, a prospective randomized study. Fertility and Sterility, 91(6), 2461-5. doi:10.1016/j.fertnstert.2008.03.051

Wang, H., \& Joseph, J. A. (1999). Quantifying cellular oxidative stress by dichlorofluorescein assay using microplate reader11Mention of a trade name, proprietary product, or specific equipment does not constitute a guarantee by the United States Department of Agriculture and does not imp. Free Radical Biology and Medicine, 27(5-6), 612-616. doi:10.1016/S0891-5849(99)00107-0

Zielonka, J., Hardy, M., \& Kalyanaraman, B. (2009). HPLC study of oxidation products of hydroethidine in chemical and biological systems: ramifications 
in superoxide measurements. Free Radical Biology \& Medicine, 46(3), 329-38. doi:10.1016/j.freeradbiomed.2008.10.031

Zielonka, J., \& Kalyanaraman, B. (2010). Hydroethidine- and MitoSOX-derived red fluorescence is not a reliable indicator of intracellular superoxide formation: another inconvenient truth. Free Radical Biology \& Medicine, 48(8), 983-1001. doi:10.1016/j.freeradbiomed.2010.01.028

Zwerschke, W., Mazurek, S., Stöckl, P., Hütter, E., Eigenbrodt, E., \& JansenDürr, P. (2003). Metabolic analysis of senescent human fibroblasts reveals a role for AMP in cellular senescence. The Biochemical Journal, 376(Pt 2), 403-411. doi:10.1042/BJ20030816 


\title{
10 Addendum
}

\subsection{Publication: Markers of cellular senescence are elevated in murine blastocysts cultured in-vitro: molecular consequences of culturing in atmospheric oxygen}

\author{
Author's personal copy
}

J Assist Reprod Genet

DOI 10.1007/s10815-014-0299-8

EMBRYO BIOLOGY

Markers of cellular senescence are elevated in murine blastocysts cultured in vitro: molecular consequences of culture in atmospheric oxygen

\section{Alexandra Meuter · Lisa-Marlen Rogmann . \\ Boris J. Winterhoff - Tamar Tchkonia .}

James L. Kirkland • Dean E. Morbeck

Received: 7 April 2014 /Accepted: 14 July 2014

C) Springer Science+Business Media New York 2014

Abstract

Purpose We aimed to determine whether embryo culture induces markers of cellular senescence and whether these effects were dependent on culture conditions.

Methods Murine blastocysts were derived in vitro and in vivo and assessed for 2 primary markers of senescence: senescence-associated $\beta$-galactosidase (SA- $\beta$-gal) and phosphorylated H2A.X ( $\gamma$-H2A.X), the latter being a mark of DNA oxidative damage. Expression of senescenceassociated genes $p 21, p 16$, and interleukin 6 (ILO) were also assessed.

Results Compared with in vivo-derived blastocysts, in vitro embryos had high levels of SA- $\beta$-gal, nuclear $\gamma$-H2A.X, an p21 mRNA expression, indicating that a senescence-like phenotype is induced by in vitro culture. To determine the role of culture conditions, we studied the effect of oxygen $(5 \%$ vs $20 \%$ ) and protein supplementation on senescence markers. Blastocysts in reduced oxygen (5\%) had low levels of both SA- $\beta$-gal and $\gamma$-H2A.X compared with blastocysts cultured in ambient oxygen. Senescence markers also were reduced in

Capsule In vitro culture of murine embryos induces cellular an molecular changes that are similar to changes observed in cellula senescence.

Alexandra Meuter and Lisa-Marlen Rogmann contributed equally to the manuscript.

A. Meuter · L.-M. Rogmann · B. J. Winterhoff · D. E. Morbeck (网) Division of Reproductive Endocrinology and Infertility, Mayo

Clinic, 200St SW, Rochester, MN 55905, USA

e-mail: morbeck.dean@mayo.edu

D. E. Morbeck

Division of Laboratory Genetics, Mayo Clinic, Rochester, MN, USA

T. Tchkonia $\cdot$ J. L. Kirkland

Robert and Arlene Kogod Center on Aging, Mayo Clinic, Rochester. MN, USA

the presence of protein, suggesting that antioxidant properties of protein reduce oxidative DNA damage in vitro.

Conclusion Elevated SA- $\beta$-gal, $\gamma$-H2A.X, and p21 suggest that in vitro stress can induce a senescence-like phenotype. Reduced oxygen during embryo culture minimizes these effects, providing further evidence for potential adverse effects of culturing embryos at ambient oxygen concentrations.

Keywords Cellular senescence · Embryo culture · In vitro stress - Oxidative stress

Abbreviations

ANOVA

BSA

DAPI

FVB

$\gamma$-H2A.X

HEPES

Ig

IL6

IVF

PBS

PCR

PCR

PVA

SA- $\beta$-galactosidase

Analysis of variance

Bovine serum albumin

4',6-diamidino-2-phenylindole

Friend Virus B

phosphorylated histone H2A.X

N-2-hydroxyethylpiperazine-N'-

2-ethane-sulfonate

Immunoglobulin

Interleukin 6

In vitro fertilization

Phosphate-buffered saline

Polymerase chain reaction

Polyvinyl alcohol

Reactive oxygen species

Introduction

Assisted reproduction via in vitro fertilization (IVF) inherently requires culturing human cells in a foreign environment at a critical stage of development. The preimplantation period begins with the oocyte and zygote, which have minimal homeostatic 
regulatory mechanisms, and ends with the blastocyst. This 4- to 5-day window of development encompasses a period of critical epigenetic reprogramming and can therefore represent a time when suboptimal culture conditions may have latent effects.

Embryos in culture are destined for 1 of 3 fates: growth arrest, cell death, or development into a blastocyst. The majority of human embryos arrest or degenerate, with typically 30 to $40 \%$ developing to the blastocyst stage [1]. In addition, in vitro-derived human blastocysts typically implant at a frequency of $50 \%$, indicating that not all blastocysts are developmentally competent. Suboptimal in vitro culture conditions alter gene expression of preimplantation embryos [2,3], with effects that may be responsible for embryonic arrest; however, the effect of in vitro stress on the fate of individual cells in the blastocyst is not clearly understood. Although programmed cell death (apoptosis) of cells exposed to stress in vitro has been studied in embryos [4,5], less is known about other cell fates.

Replicative cellular senescence is a term used to describe cells that are unable to replicate yet remain viable and metabolically active [6]. Senescence can be induced prematurely by various stressors such as oncogenes, irradiation, or oxidation [7]. This stress-induced premature senescence is a phenomenon of both in vitro cell culture and the in vivo setting. Markers to detect cellular senescence include senescenceassociated $\beta$-galactosidase (SA- $\beta$-galactosidase) [8], proteins associated with DNA damage repair such as phosphorylated histone H2A.X ( $\gamma$-H2A.X) [9], and increased expression of genes involved in the stress response. Cells in senescence differ from apoptotic cells because senescent cells remain viable and metabolically active.

In somatic cells, reactive oxygen species (ROS) are implicated in the induction of cellular senescence [10] and in premature senescence with elevated oxidative stress during in vitro culture $[11,12]$. These observations may apply to preimplantation embryos as well. Bovine embryos cultured with $20 \%$ oxygen have significantly elevated levels of intracellular ROS and higher frequencies of permanent embryo arrest at the 2- to 4-cell stage compared with embryos cultured with $5 \%$ oxygen [13]. Embryos that arrested at the 2- to 4-cell stage had $\gamma$-H2A.X foci, suggesting that the senescence pathway may be active in early embryos $[14,15]$. Because culture to the blastocyst stage in ambient oxygen is a common practice in clinical IVF laboratories, stress-induced premature senescence may occur in human blastocysts, with downstream effects on development.

The objective of the current study was to determine whether markers of premature senescence appeared in mouse blastocysts in response to in vitro culture conditions. Our first aim was to compare the senescence markers SA- $\beta$-galactosidase, $\gamma$-H2A.X, and expression of $p 21, p 16$, and interleukin 6 (IL6) for blastocysts derived in vivo and in vitro. We then determined the impact of oxygen concentration, with or without protein supplementation, on SA- $\beta$-galactosidase and $\gamma$ H2A.X for blastocysts cultured in vitro.

\section{Materials and methods}

The manuscript does not contain clinical studies or patient data. All procedures involving animals were performed under an active Institutional Animal Care and Use Committee protocol

Embryo collection and culture

Friend Virus B (FVB) mice (4-7 weeks old) were superovulated with intraperitoneal injections of $5 \mathrm{IU}$ pregnan mare's serum (National Hormone and Peptide Program) followed $48 \mathrm{~h}$ later with $5 \mathrm{IU}$ of human chorionic gonadotropin (APP Pharmaceuticals). Female mice were caged individually with male CF-1 mice for breeding overnight. Female mice were checked for copulation by observing a vaginal plug of semen the next morning.

\section{In vitro group}

Pregnant mice with vaginal plugs were euthanized at 18 to $20 \mathrm{~h}$ after human chorionic gonadotropin administration. Oviducts were excised and flushed with human tubal fluid medium containing N-2-hydroxyethylpiperazine-N'-2-ethanesulfonate (HEPES) and $5 \mathrm{mg} / \mathrm{mL}$ human serum albumin (Cooper Surgical). One-cell embryos were cultured in Global medium (IVFonline) under mineral oil (Fisher Scientific) with ambient air with $7.0 \% \mathrm{CO}_{2}$ at $37{ }^{\circ} \mathrm{C}$. Embryos were cultured for $96 \mathrm{~h}$ after embryo collection and development was assessed every $24 \mathrm{~h}$. Embryos at the expanded or hatching stage at $96 \mathrm{~h}$ were included.

\section{In vivo group}

Pregnant mice were euthanized 3.5 days after coitum to obtain in vivo control blastocysts, which provides embryos at a similar developmental stage to in vitro blastocysts at $96 \mathrm{~h}$ of culture [16]. Oviducts were excised and flushed with human tubal fluid medium to obtain blastocysts.

\section{Experiment one}

In vitro and in vivo blastocysts were obtained from 3 replicates with 30 blastocysts for each marker studied. Markers included SA- $\beta$-galactosidase, $\gamma$-H2A.X, and expression of p21, p16, and IL6.

\section{Experiment two}

Effects of oxygen and protein were studied using a $2 \times 2$ factorial design, with 2 levels of oxygen ( $5 \%$ vs $20 \%)$, with or without $10 \% \mathrm{v} / \mathrm{v}$ protein (serum substitute supplement (SSS), Irvine Scientific). After $96 \mathrm{~h}$ of culture, blastocysts were obtained from a minimum of 3 replicates, with at least 
30 blastocysts obtained for both SA- $\beta$-galactosidase and $\gamma$ H2A.X.

\section{Blastocyst preparation}

Blastocysts from each experimental group were washed 3 times in phosphate-buffered saline (PBS; pH 7.4; Invitrogen) containing $0.1 \%$ polyvinyl alcohol (PVA; Sigma Aldrich) and were either immediately snap-frozen in liquid nitrogen for RNA isolation or processed for SA- $\beta$-galactosidase or $\gamma$-H2A.X and 4',6-diamidino-2-phenylindole (DAPI) analysis.

Senescence-associated $\beta$-galactosidase assay

Blastocysts from each experimental group were fixed in $2 \%$ paraformaldehyde (ElectronMicroscopy Sciences) and $0.2 \%$ glutaraldehyde (Sigma Aldrich) in PBS-PVA under mineral oil for $10 \mathrm{~min}$ at room temperature. Blastocysts were washed 3 times in PBS-PVA and incubated for $16 \mathrm{~h}$ in a $\mathrm{CO}_{2}$-free incubator at $37^{\circ} \mathrm{C}$ in SA- $\beta$-galactosidase assay solution. The SA- $\beta$-galactosidase assay solution consisted of $50 \mu \mathrm{L}$ X-gal $(20 \mathrm{mg} / \mathrm{mL}$; American Bioanalytical), $200 \mu \mathrm{L} 0.2 \mathrm{M}$ citric acid (pH 6.0; Sigma Aldrich), $50 \mu \mathrm{L} 100 \mathrm{mM}$ potassium ferrocyanide (Sigma Aldrich), $50 \mu \mathrm{L} 100 \mathrm{mM}$ potassium ferricyanide (MP Biomedicals, Solon, $\mathrm{OH}$ ), $30 \mu \mathrm{L} 5 \mathrm{M}$ sodium chloride (Boston BioProducts), $2 \mu \mathrm{L} 1 \mathrm{M}$ magnesium chloride (Boston BioProducts), and $620 \mu \mathrm{L}$ molecular biology-grade water (Cellgro; Mediatech, Inc). A positive control for $\beta$ galactosidase activity was performed at $\mathrm{pH}$ 4.0. Assay solution was prepared fresh for each replicate.

Following incubation, blastocysts were washed extensively with PBS-PVA and assessed using a light microscope at $400 \times$ magnification (Nikon). Embryos were considered positive when blue staining was evident.

\section{$\gamma$-H2A.X immunofluorescence staining}

Each experimental group of embryos was fixed in $4 \%$ paraformaldehyde in PBS under mineral oil for $1 \mathrm{~h}$ at $4{ }^{\circ} \mathrm{C}$. Embryos were washed 3 times in PBS with $0.1 \%$ Tween 20 (Bio-Rad) and permeabilized in PBS with $1.0 \%$ Triton X-100 (Sigma Aldrich) for $1 \mathrm{~h}$ at $4{ }^{\circ} \mathrm{C}$. Embryos were washed 3 times in PBS with $0.1 \%$ Tween 20 and blocked in PBS containing $8 \%$ bovine serum albumin (BSA) overnight at $4{ }^{\circ} \mathrm{C}$. Embryos were stained with primary anti- $\gamma-\mathrm{H} 2 \mathrm{~A}$.X antibody (rabbit anti-mouse monoclonal immunoglobulin [Ig] G; Life Technologies) overnight at $4{ }^{\circ} \mathrm{C}$ using a dilution of 1:300 in 1\% BSA/PBS. After this, embryos were washed 3 times in PBS with $0.1 \%$ Tween 20 and incubated with a secondary fluorescein isothiocyanate-labeled antibody (anti-rabbit IgG; Life Technologies), diluted 1:500 in $1 \% \mathrm{BSA} / \mathrm{PBS}$, for $2 \mathrm{~h}$ at room temperature. The immunostained embryos were washed 3 times in PBS with $0.1 \%$ Tween 20 and counterstained with $3 \%$ DAPI (Abbott Molecular) in Vectashield mounting medium (Vector Laboratories). Confocal images were obtained with a LSM510 or LSM780 microscope (Zeiss). Blastocysts were scanned in 3 dimensions using the Z-stack function, with Z-stack images projected as overlays. Each nucleus of a blastomere with more than 5 foci of $\gamma$-H2A.X was considered positive [17]. Furthermore, we determined the percentage of nuclei within a blastocyst that was $\gamma$-H2A.X positive.

\section{RNA extraction and amplification}

For every biological replicate, total RNA was extracted from a pool of 10 blastocysts from each experimental group using the Prelude Direct Lysis Module (NuGen Technologies, Inc). The Ovation Pico WTA System (NuGen Technologies) was used to amplify the isolated total RNA $(5 \mu \mathrm{L})$ according to the manufacturer's instructions. After amplification, samples were purified using DNA Clean \& Concentrator (Zymo Research Corp). Concentrations of cDNA samples were confirmed with NanoDrop 1000 spectrophotometer analysis (Thermo Fisher Scientific, Inc).

Relative real-time polymerase chain reaction

Gene expression was determined with real-time polymerase chain reaction (PCR) using the TaqMan Gene Expression Assay in a 7500 Fast Real-Time PCR System (Applied Biosystems). In brief, $10 \mu \mathrm{L}$ of TaqMan Fast Advanced Master Mix were mixed with $5 \mu \mathrm{L}$ of amplified cDNA from each biological replicate, $1 \mu \mathrm{L}$ of the appropriate TaqMan primer (to detect $p 21, p 16$, or $I L 6$ ), and $4 \mu \mathrm{L}$ of water. A housekeeping gene encoding the TATA-box binding protein $(T B P)$ was used as an internal standard [18]. The in vivo group was used as the reference group. Expression levels for each mRNA transcript were determined relative to the reference group and housekeeping gene. We used the comparative threshold cycle method [19] for calculation. Five biological replicates, each with 3 technical replicates, were performed for the in vitro and in vivo groups.

Statistical analysis

Results of the experiments were analyzed by 1-way analysis of variance (ANOVA) and significance was determined by the Student $t$ test for the in vivo vs in vitro experiment. Results of experiment 2 were analyzed by ANOVA and means were compared with Tukey's test. $P$ values $<.05$ were considered statistically significant. Analysis was performed using JMP software (SAS Institute, Inc) and Prism (GraphPad Software, Inc). 


\section{Results}

Experiment one: in vivo vs in vitro blastocysts

The classical senescence marker SA- $\beta$-galactosidase was readily apparent in in vitro-derived blastocysts (Fig. 1a); $76.7 \%$ of blastocysts were positive for SA- $\beta$-galactosidase compared with $3.3 \%$ of the in vivo group $(P<.001$; Fig. 1b). As an internal positive control, we performed the $\beta$-galactosidase assay at $\mathrm{pH} 4.0$; under this condition, all in vivo and in vitro blastocysts were positive for $\beta$ galactosidase (data not shown).

DNA damage response, as measured with phosphorylation of the histone variant H2A.X $(\gamma-\mathrm{H} 2 \mathrm{~A} . \mathrm{X})$, was increased in blastocysts from the in vitro group (Fig. 2a). In total, $45.2 \%$ of nuclei from in vitro blastocysts had more than $5 \gamma$-H2A.X foci, whereas only $14.2 \%$ of the nuclei of in vivo blastocysts were $\gamma$-H2A.X positive $(P<.001$; Fig. $2 b)$.

Another marker of cellular senescence is increased expression of specific cell cycle and inflammation genes. Expression of $p 2 I$ was 22.1 -fold higher in in vitro blastocysts compared with the in vivo group ( $P=.046$; Fig. 3 a). Expression of IL6 was similar between the 2 groups $(P=.98$; Fig. $3 \mathrm{~b})$. Expression of $p 16$ was not detected in either group.

Experiment two: effect of oxygen and protein on markers of cellular senescence

As described above, markers of senescence were present in blastocysts derived from in vitro culture without protein in $20 \%$ oxygen. To determine whether these markers were dependent on culture conditions, we designed a $2 \times$ 2 factorial study to compare the effects of 2 factors associated with oxidative stress, oxygen concentration and protein supplementation.

Blastocysts cultured in $20 \%$ oxygen were positive for SA- $\beta$-galactosidase (Fig. 4); the proportion of positive blastocysts was similar for embryos cultured with or without protein supplementation ( $50.0 \%$ vs $63.3 \%$, respectively). In contrast, for blastocysts cultured in $5 \%$ oxygen, only $10.0 \%$ stained positive for SA- $\beta$-galactosidase when protein was present but $26.7 \%$ were positive when protein was absent $(P<.05)$.

The DNA damage repair response marker, $\gamma$-H2A.X, was similarly affected by oxygen and by protein in the reduced oxygen group (Fig. 5a). Fewer blastomeres per blastocyst in the reduced-oxygen group, with or without protein supplementation, had at least 5 foci in the nucleus ( 2.8 vs $11.2 \%$, respectively) compared with blastocysts in the $20 \%$ oxygen group ( 29.3 vs $36.0 \%$, respectively; $P<.05$ ). Although blastocyst development for all treatment groups exceeded $75 \%$ (data not shown), total cell numbers were reduced in the group cultured in $20 \%$ oxygen without protein supplementation $(P<.01$; Fig. 5b).

\section{Discussion}

Most mammalian embryos undergo permanent growth arrest during the first 5 days of development in vitro or develop to the blastocyst stage but then fail to implant [1]. The reasons for arrest and the mechanisms that regulate this process are poorly understood. In our study of murine blastocysts, we investigated the presence and extent of markers of the senescence response in blastocysts developed in vitro and observed significantly higher expression of markers such as SA- $\beta$ galactosidase, $\gamma$-H2A.X, and $p 21$ compared with in vivoderived blastocysts. These findings indicate that components of the senescence response can be induced in embryos by stressors associated with in vitro culture. These energydependent cell responses to stress, particularly to DNA damage, may lead to cell cycle arrest and ultimately may affect viability or long-term development. Of potential importance for clinical assisted reproduction laboratories, we found that this senescence-like phenotype largely is due to culture in atmospheric oxygen, with 6 - to 7 -fold more $\gamma$-H2A.X-positive cells for blastocysts cultured in $20 \%$ oxygen and similar levels of $\gamma$-H2A.X-positive cells when comparing blastocysts cultured in $5 \%$ oxygen vs blastocysts cultured in vivo.

When actively growing cells accumulate a critical level of cellular damage, proliferation ceases and cells undergo programmed death (apoptosis or autophagy) or permanent cell cycle arrest (senescence). Although apoptosis has been reported in embryos [4, 5], it typically occurs in less than $10 \%$ of blastomeres in blastocysts. Apoptosis represents an end point of cell fate: the culmination of cellular damage and the signature of a cell that is unable to overcome intrinsic defects or extrinsic insults. Cellular senescence is another programmed cell response to in vitro stress that, similar to apoptosis, is the culmination of damage and corresponding cellular responses. However, senescent cells, unlike apoptotic cells, remain viable and metabolically active, even though they do not divide [7]. Classical cellular senescence is linked to tumor suppression and aging in vivo [6] and is characterized by expression of cell cycle suppressors p16 and $p 21$, expression of SA- $\beta$-galactosidase, persistent nuclear foci of $\gamma$ H2A.X, and dysfunctional telomeres [20].

Significant evidence indicates that most of the elements necessary to trigger a senescence phenotype exist during in vitro culture of embryos at ambient oxygen concentrations. High oxygen induces oxidative stress and ROS in embryos $[13,21-23]$ that lead to increased apoptosis $[24,25]$ and DNA damage relative to in vivo embryos [26] and embryos cultured in $5 \%$ oxygen $[21,23]$. Betts and King $[14]$ proposed that

\section{Springer}




\section{Author's personal copy}

J Assist Reprod Genet

Fig. 1 A, Representative images

of blastocysts (left: in vivo; right:

in vitro) after staining for

senescence-associated (SA-)

$\beta$-galactosidase (blue color;

original magnification, $\times 400$ )

$B$, Percentage of blastocysts

positive for SA- $\beta$-galactosidase

activity (data shown are

mean \pm standard error, $P<.001$ )

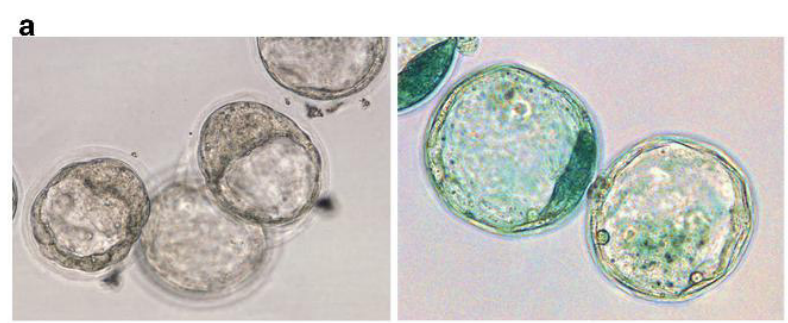

b

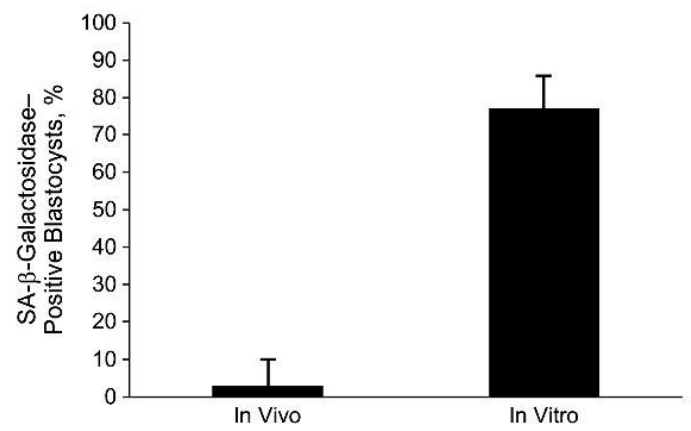

permanent arrest of bovine embryos at the 2-to 4- cell stage is due to oxidative stress, which suggests that blastomeres of the preimplantation embryo are capable of responding with a senescence-like stress-signaling pathway. They demonstrated that arrested 2- to 4-cell bovine embryos have elevated levels of intracellular ROS [13], are still metabolically active, have high levels of $\gamma$-H2A.X foci [15], and have increased levels of the stress-sensing protein $p 66 S h c$ [13]. Although embryos that arrest at the cleavage stage appear to have a senescent phenotype, senescence as a cell fate of blastomeres in embryos at later stages of development has not been reported.

The tumor suppressor $p 53$ does not appear to have a role in early embryo senescence [13], but the $p 53$ pathway is activated in blastocysts in response to genotoxic stress or in vitro culture [27-31]. DNA damage thus activates the DNA damage response, including the $p 53$ pathway, which can lead to apoptosis or senescence. The role of apoptosis in blastocysts is not clear, however. Using a bovine model, Leidenfrost and colleagues [32] observed permanent cell cycle arrest and nonapoptotic cell death in blastocysts, the latter occurring mostly in the inner cell mass. Our findings suggest that although DNA damage due to ambient oxygen may not reach the threshold necessary to induce cell death, it nonetheless results in significant molecular responses that at a minimum require resources to repair; this response may ultimately lead to cell cycle arrest.

An early marker of cellular senescence is SA- $\beta$ galactosidase [8], an enzyme present in most senescent cells and induced by prolonged culture of somatic cells. Our study demonstrates for the first time that SA- $\beta$-galactosidase is present in in vitro-derived murine blastocysts. Classic acid $\beta$-galactosidase can be found in all eukaryotic cells in the lysosome and is distinguished from SA- $\beta$-galactosidase by its $\mathrm{pKa}$, with the former active at a $\mathrm{pH}$ of 6.0. These enzymes are important for processing cellular waste components (eg, gangliosides, glycosaminoglycans, glycoproteins) by hydrolyzing $\beta$-linked terminal galactosyl residues from cell-derived (as well as artificial) substrates [33].

The importance of SA- $\beta$-galactosidase detection in embryos remains to be determined, but it could suggest an increase in lysosomal biogenesis, consistent with oxidative stress. Although SA- $\beta$-galactosidase is the first marker used to establish a senescent phenotype, the biological significance of this assay remains in question. SA- $\beta$-galactosidase activity at pH 6 increases in some nonsenescent cells [34] and may simply reflect an increase in lysosomal biogenesis [35]. Oxidative stress from mitochondrial ROS production during aging $[10,35]$ or exogenous ROS can lead to accumulation of oxidation products such as lipofuscin [36]; if lysosomal mass increases in an attempt to compensate for the high amount of oxidation products, then higher SA- $\beta$-galactosidase activity results [37]. 
Fig. 2 A, Upper left: In vitro blastocyst stained with DAPI (blue). Upper right: In vitro blastocyst stained with DAPI and blastocyst stained with DAPI and overlaid with $\gamma$ H2A.X (green). Lower len, In vivo blastocyst stained with DAPI. Lower right: In vivo blastocyst stained wi DAPI and overlaid with $\gamma$ H2A.X. B, Percentage of cells in each blastocyst positive for $\gamma$ H2A.X $(>5 \gamma$-H2A.X foci/nucleus) in the in vivo and in vitro groups (data shown are mean \pm standard error; $P<001)$ DAPI denotes 4', 6-diamidino-2phenylindole; $\gamma$-H2A.X, phosphorylated histone H2A.X
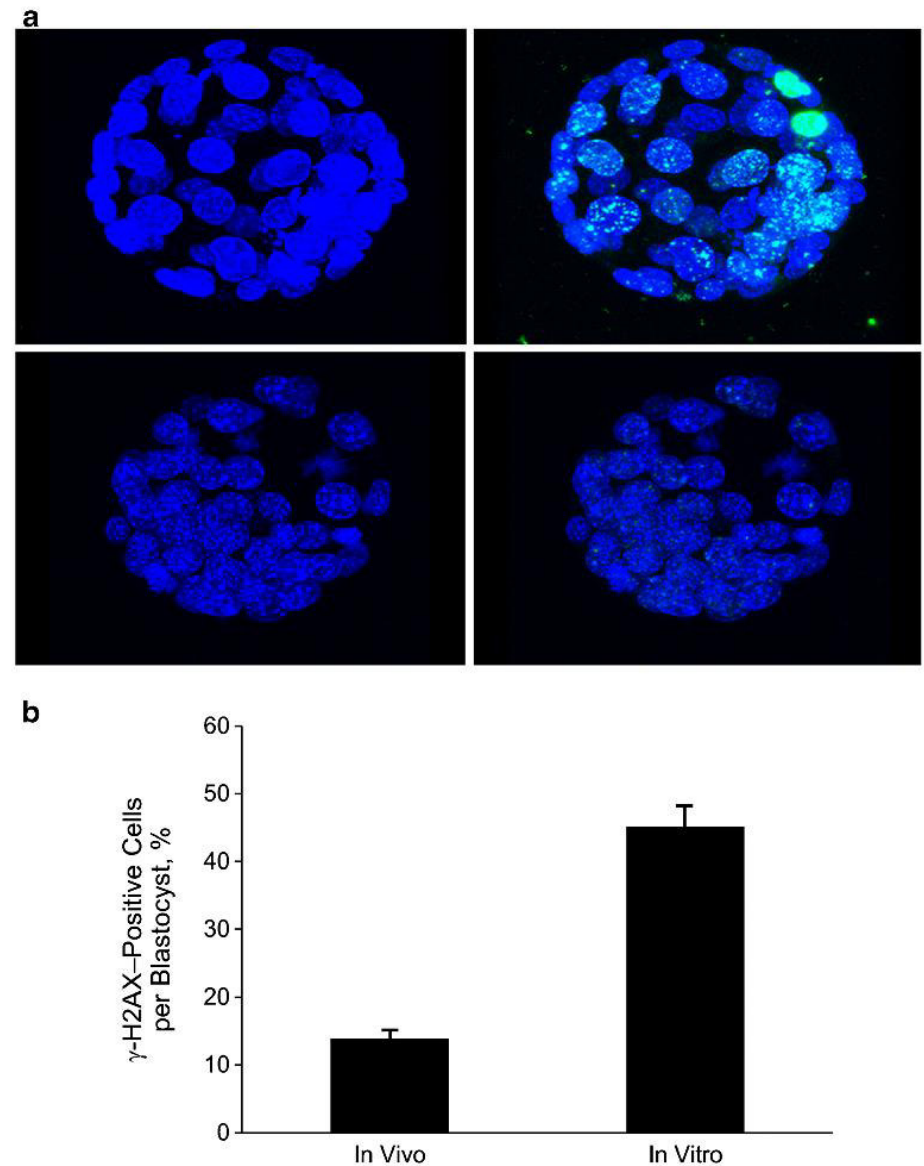

$\gamma$-H2A.X is a highly sensitive marker of DNA damage [38] and is necessary for classification of the senescent phenotype [39]. $\gamma$-H2A.X forms foci at the site of double-strand breaks, causing recruitment of several DNA repair and cell cycle checkpoint proteins. Our results illustrate that embryos cultured in vitro at $20 \%$ oxygen have a considerable number of cells with extensive DNA repair activity, likely due to oxidative stress. We used the threshold of at least $5 \gamma$-H2A.X foci per nucleus [17] to classify cells as senescent. However, because the DNA damage response must be persistent to induce senescence [40], it is possible that these are transient foci that are repairable and, once restored, allow cells to continue proliferation. Although ours is the first report of $\gamma$ H2A.X in blastocysts and the fate of affected blastomeres is

\section{Springer}

unknown, a prior report has shown that bovine embryos that arrest at the 2-cell stage are positive for $\gamma$-H2A.X and proliferating 2-cell embryos do not show expression of $\gamma$-H2A.X; taken together, $\gamma$-H2A.X may be a marker of senescence in preimplantation embryos $[14,15]$. Similarly, genotoxic stress induces $\gamma$-H2A.X in 2-cell mouse embryos and results in cell cycle arrest [41].

The cellular response to DNA damage results in senescence via the $p 53-p 21$ or $p 16-\mathrm{pRB}$ cell checkpoint pathways [7]. We demonstrated that the potent cell cycle inhibitor $p 21$, but not $p 16$, is upregulated during in vitro culture. $p 21$ is a cyclin-dependent kinase inhibitor that is upregulated in dormant mouse blastocysts during delayed implantation [42] and causes cell cycle arrest in irradiated embryos [43]. DNA 

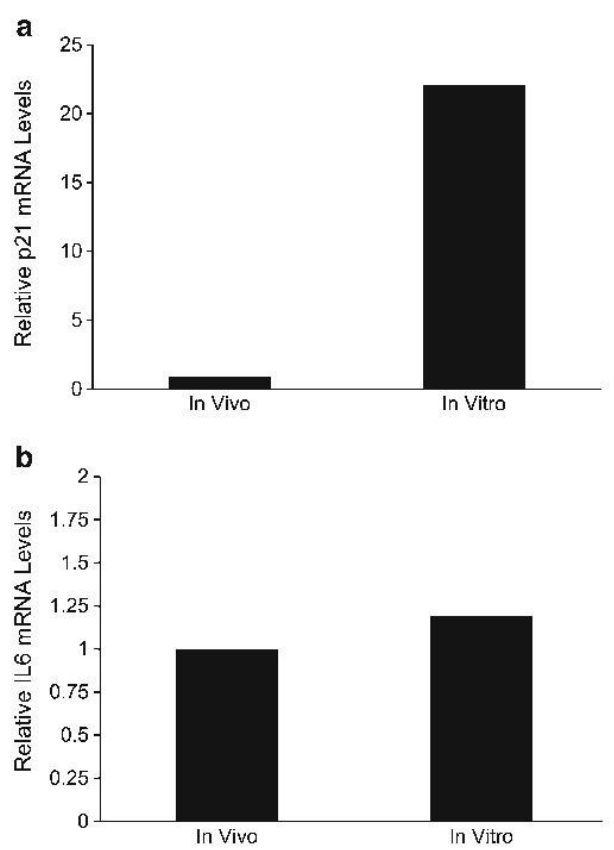

Fig. 3 Relative expression of markers of senescence in blastocysts derived in vivo and in vitro. Data shown are mean \pm standard error. A, Expression of $21(P<.05)$. B, Expression of interleukin 6 (IL6) $(P=.98)$

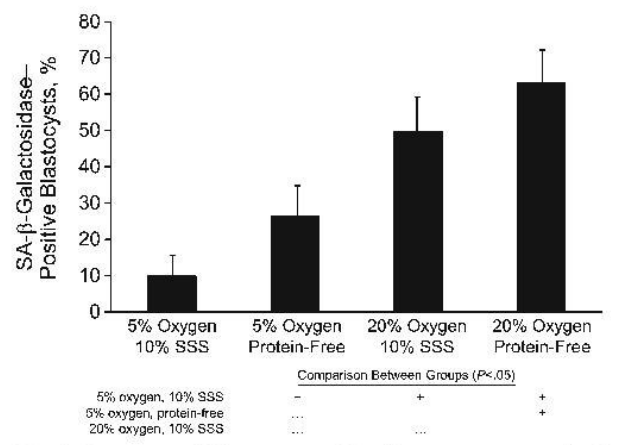

Fig. 4 Percentage of blastocysts positive for senescence-associated (SA-) $\beta$-galactosidase activity, stratified by oxygen concentration and protein supplementation. Data shown are mean \pm standard error. All culture conditions were compared individually in all possible combinations (each row shows comparison with the condition indicated for the histogram bar above); those with significant differences $(P<.05)$ are indicated $(+)$. SSS denotes serum substitute supplement

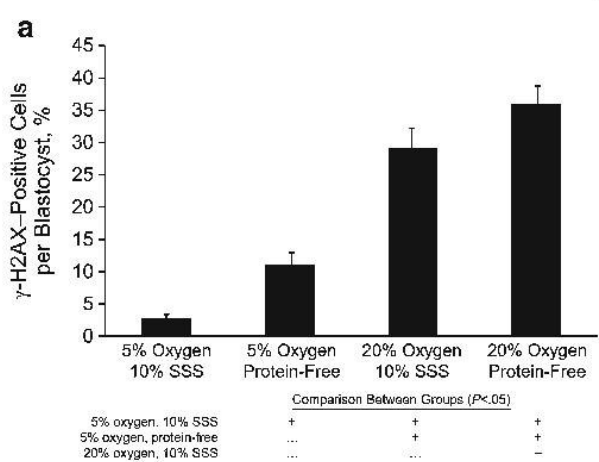

b

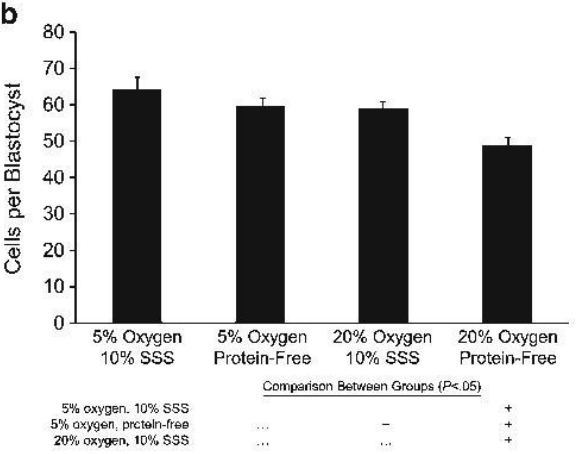

Fig. 5 A, Percentage of cells in each blastocyst positive for $\gamma$-H2A.X $(>5 \gamma$-H2A.X foci/nucleus), stratified by oxygen concentration and protein supplementation. B, Number of cells per blastocyst for each oxygen and protein supplementation group. Data shown are mean \pm standard error All culture conditions were compared individually in all possible combinations (each row shows comparison with the condition indicated for the histogram bar above); those with significant differences $(P<.05)$ are indicated $(+)$. SSS denotes serum substitute supplement

damage, specifically that associated with $\gamma$-H2A.X, initiates the $p 53-p 21$ signaling pathway at the onset of cellular senescence, whereas unphosphorylated H2A.X leads to degradation of $p 21$ and cell death [7,9]. The role of p16 (another cyclin-dependent kinase inhibitor) in the induction of senescence is less clear. Some studies support p16-driven senescence $[44,45]$, whereas others could not find any expression of pl6 [46, 47]. We did not detect any pl6 RNA, consistent with prior work suggesting that the pRB pathway does not develop until after implantation [48]. In contrast, $p 21$ expression was higher in the in vitro group than the in vivo group, providing additional evidence that the senescence response may be active in blastocysts because $p 21$ is a key target of $p 53$-dependent senescence [49]. Another feature of senescent cells is a proinflammatory phenotype, mostly seen in chronic 
inflammation and commonly assessed by IL6 expression levels [20]. Because we did not observe a difference in IL6 gene expression between in vitro and in vivo embryos, the response to oxidative stress in in vitro blastocysts may be a premature, stress-induced, senescence-like phenotype, with the primary effect of upregulating $p 21$.

The effect of in vitro culture on embryo health remains an important area of investigation because questions about potential adverse effects of culture continue to be raised $[50,51]$. In the present study, embryos were cultured in $20 \%$ oxygen, which likely contributed to the extent of oxidative stress because atmospheric oxygen levels adversely affect outcomes in most species studied $[52,53]$ and alter genetic imprinting [3]. Although reduced-oxygen culture is universally adopted in bovine embryo production and results in improved live birth rates for human IVF $[54,55]$, many clinical IVF laboratories continue to use $20 \%$ oxygen [56]. Assessment of apoptosis in embryos shows greater apoptosis in in vitroderived bovine embryos compared with in vivo embryos [25], suggesting the potentially deleterious effects of a suboptimal culture environment [57]. The detection of both apoptotic and arrested cells in bovine blastocysts [32] indicates coexistence of these 2 cell fates in a single blastocyst, resulting in fewer total cells. Cell stress might therefore lead to embryo lethality because of the loss of a critical number of cells.

In summary, markers of cellular senescence, including SA- $\beta$-galactosidase, $\gamma$-H2A.X, and $p 21$, are expressed in murine blastocysts cultured in vitro and indicate that a senescence-like state may be induced through oxidative stress and suboptimal culture conditions. Culture in $5 \%$ oxygen reduced markers to levels similar to that seen with in vivo embryos, illustrating another mechanism of damage induced by culture at ambient oxygen. The fate of these DNAdamaged cells in blastocysts is unknown, but the possibilities include repair with transient cell cycle arrest, senescence with complete cell cycle arrest, or apoptotic cell death. Further studies of DNA damage, the cellular senescence pathway in embryos, and the role of oxidative stress and other embryo culture conditions are warranted.

Conflict of interest The authors declare that they have no conflict of interest.

\section{References}

1. Thomas MR, Sparks AE, Ryan GL, Van Voorhis BJ. Clinical predictors of human blastocyst formation and pregnancy after extended embryo culture and transfer. Fertil Steril. 2010;94(2):543-8. Epub 2009 May 5.

2. Doherty AS, Mann MR, Tremblay KD, Bartolomei MS, Schultz RM. Differential effects of culture on imprinted H19 expression in the preimplantation mouse embryo. Biol Reprod. 2000;62(6): 1526-35.
3. Rinaudo P, Schultz RM. Effects of embryo culture on global pattern of gene expression in preimplantation mouse embryos. Reproduction. 2004;128(3):301-11.

4. Hardy K. Cell death in the mammalian blastocyst. Mol Hum Reprod. 1997;3(10):919-25.

5. Jurisicova A, Acton BM. Deadly decisions: the role of genes regulating programmed cell death in human preimplantation embryo development. Reproduction. 2004;128(3):281-91.

6. Hayflick L, Moorhead PS. The serial cultivation of human diploid cell strains. Exp Cell Res. 1961;25:585-621.

7. Campisi J, d'Adda di Fagagna F. Cellular senescence: when bad things happen to good cells. Nat Rev Mol Cell Biol. 2007;8(9): $729-40$.

8. Dimri GP, Lee X, Basile G, Acosta M, Scott G, Roskelley C, et al. A biomarker that identifies senescent human cells in culture and in aging skin in vivo. Proc Natl Acad Sci U S A. 1995;92(20):9363-7. 9. Fragkos $\mathrm{M}$, Jarvansu J, Beard P. H2AX is required for cell cycle arrest via the $p 53 / p 21$ pathway. Mol Cell Biol. 2009;29(10):2828-40. Epub 2009 Mar 9

10. Passos JF, von Zglinicki T, Kirkwood TB. Mitochondria and ageing: winning and losing in the numbers game. Bioessays. 2007;29(9): 908-17.

11. Frippiat C, Chen QM, Zdanov S, Magalhaes JP, Remacle J, Toussaint $\mathrm{O}$. Subcytotoxic $\mathrm{H} 2 \mathrm{O} 2$ stress triggers a release of transforming growth factor-beta 1 , which induces biomarkers of cellular senescence of human diploid fibroblasts. J Biol Chem 2001;276(4):2531 7. Epub 2000 Nov 1.

12. Passos JF, Saretzki G, von Zglinicki T. DNA damage in telomeres and mitochondria during cellular senescence: is there a connection. Nucleic Acids Res. 2007;35(22): 7505-13. Epub 2007 Nov 5.

13. Favetta LA, St John EJ, King WA, Betts DH. High levels of p66shc and intracellular ROS in permanently arrested early embryos. Free Radic Biol Med. 2007;42(8):1201-10. Epub 2007 Jan 13.

14. Betts DH, King WA. Genetic regulation of embryo death and senescence. Theriogenology. 2001;55(1):171-91.

15. Betts DH, Madan P. Permanent embryo arrest: molecular and cellular concepts. Mol Hum Reprod. 2008;14(8):445-53. Epub 2008 May 29.

16. McLaren A, Bowman P. Genetic effects on the timing of early development in the mouse. J Embryol Exp Morphol. 1973;30(2): develop.

17. Lawless C, Wang C, Jurk D, Merz A, Zglinicki TV, Passos JF Quantitative assessment of markers for cell senescence. Exp Gerontol. 2010;45(10):772-8. Epub 2010 Feb 1.

18. Willems E, Mateizel I, Kemp C, Cauffman G, Sermon K, Leyns L. Selection of reference genes in mouse embryos and in differentiating human and mouse ES cells. Int J Dev Biol. 2006;50(7):627-35.

19. Livak KJ, Schmittgen TD. Analysis of relative gene expression data using real-time quantitative PCR and the 2(-Delta Delta $C(T))$ Method. Methods. 2001;25(4):402-8.

20. Rodier F, Campisi J. Four faces of cellular senescence. J Cell Biol 2011;192(4):547-56. Epub 2011 Feb 14.

21. Takahashi M, Keicho K, Takahashi H, Ogawa H, Schultz RM, Okan A. Effect of oxidative stress on development and DNA damage in invitro cultured bovine embryos by comet assay. Theriogenology. 2000;54(1):137-45

22. Guerin P, El Mouatassim S, Menezo Y. Oxidative stress and protection against reactive oxygen species in the pre-implantation embryo and its surroundings. Hum Reprod Update. 2001;7(2): 175-89.

23. Kitagawa Y, Suzuki K, Yoneda A, Watanabe T. Effects of oxygen concentration and antioxidants on the in vitro developmental ability, production of reactive oxygen species (ROS), and DNA fragmentation in porcine embryos. Theriogenology. 2004;62(7):1186-97.

24. Van Soom A, Yuan YQ, Peelman LJ, de Matos DG, Dewulf J, Laevens H, et al. Prevalence of apoptosis and inner cell allocation

\section{Springer}


in bovine embryos cultured under different oxygen tensions with or without cysteine addition. Theriogenology. 2002;57(5):1453-65.

25. Pomar FJ, Teerds KJ, Kidson A, Colenbrander B, Tharasanit T, Aguilar B, et al. Differences in the incidence of apoptosis between in vivo and in vitro produced blastocysts of farm animal species: a comparative study. Theriogenology. 2005;63(8):2254-68. Epub 2004 Nov 28 .

26. Takahashi M, Saka N, Takahashi H, Kanai Y, Schultz RM, Okano A. Assessment of DNA damage in individual hamster embryos by comet assay. Mol Reprod Dev. 1999;54(1):1-7.

27. Jurisicova A, Latham KE, Casper RF, Casper RF, Varmuza SL. Expression and regulation of genes associated with cell death during murine preimplantation embryo development. Mol Reprod Dev. 1998:51(3):243-53.

28. Lichnovsky V, Kolar Z, Murray P, Hlobilkova A, Cernochova D, Pospisilova $\mathrm{E}$, et al. Differences in $p 53$ and $\mathrm{Bcl}-2$ expression in Pospisilova $\mathrm{E}$, et al. Differences in $p 53$ and $\mathrm{Bcl}-2$ expression in
relation to cell proliferation during the development of human emrelation to cell proliferation during the
bryos. Mol Pathol. 1998;51(3):131-7.

29. Frenkel J, Sherman D, Fein A, Schwartz D, Almog N, Kapon A, et al. Accentuated apoptosis in normally developing $p 53$ knockout mouse embryos following genotoxic stress. Oncogene. 1999;18(18): 2901-7.

30. Chandrakanthan V, Chami O, Stojanov T, O'Neill C. Variable expressivity of the tumour suppressor protein TRP53 in cryopreserved human blastocysts. Reprod Biol Endocrinol. 2007;5:39.

31. Ganeshan L, Li A, O'Neill C. Transformation-related protein 53 expression in the early mouse embryo compromises preimplantation embryonic development by preventing the formation of a proliferating inner cell mass. Biol Reprod. 2010;83(6):95864. Epub 2010 Aug 25.

32. Leidenfrost S, Boelhauve M, Reichenbach M, Gungor T, Reichenbach HD, Sinowatz F, et al. Cell arrest and cell death in mammalian preimplantation development: lessons from the bovine model. PLoS ONE. 2011;6(7):e22121. Epub 2011 Jul 21.

33. Ishii N, Oohira T, Oshima A, Sakuraba H, Endo F, Matsuda I, et al. Clinical and molecular analysis of a Japanese boy with Morquio B disease. Clin Genet. 1995;48(2):103-8.

34. Severino J, Allen RG, Balin S, Balin A, Cristofalo VJ. Is betagalactosidase staining a marker of senescence in vitro and in vivo? Exp Cell Res. 2000;257(1):162-71.

35. Zwerschke W, Mazurek S, Stockl P, Hutter E, Eigenbrodt E, JansenDurr P. Metabolic analysis of senescent human fibroblasts reveals a role for AMP in cellular senescence. Biochem J. 2003;376(Pt 2): 403-11.

36. Sitte N, Merker K, Grune T, von Zglinicki T. Lipofuscin accumulation in proliferating fibroblasts in vitro: an indicator of oxidative stress. Exp Gerontol. 2001;36(3):475-86.

37. Liton PB, Lin Y, Gonzalez P, Epstein DL. Potential role of lysosomal dysfunction in the pathogenesis of primary open angle glaucoma. Autophagy. 2009;5(1):122-4. Epub 2009 Jan 31.

38. Mah LJ, El-Osta A, Karagiannis TC, gammaH2AX: a sensitive molecular marker of DNA damage and repair. Leukemia. 2010;24(4): molecular marker of DNA

39. von Zglinicki T, Saretzki G, Ladhoff J, d'Adda di Fagagna F, Jackson SP. Human cell senescence as a DNA damage response. Mech Ageing Dev. 2005;126(1):111-7

40. d'Adda di Fagagna F. Living on a break: cellular senescence as a DNA-damage response. Nat Rev Cancer. 2008;8(7):512-22.

41. Mu XF, Jin XL, Farmham MM, Li Y, O’Neill C. DNA damage-sensing kinases mediate the mouse 2-cell embryo's response to genotoxic stress. Biol Reprod. 2011;85(3):524-35. Epub 2011 May 18.
42. Hamatani T, Carter MG, Sharov AA, Ko MS. Dynamics of global gene expression changes during mouse preimplantation development. Dev Cell. 2004;6(1):117-31.

43. Adig SK, Toyoshim (1) Shimum T Taked J, Uematsu N, Niwa O. Delayed and stage specific phosphorylation of $\mathrm{H} 2 \mathrm{AX}$ during preimplantation development of gamma-irradiated mouse embryos. Reproduction, 2007;133(2):415-22.

44. Beausejour CM, Krtolica A, Galimi F, Narita M, Lowe SW, Yaswen $\mathrm{P}$, et al. Reversal of human cellular senescence: roles of the $p 53$ and p16 pathways. EMBO J. 2003;22(16):4212-22.

45. Sviderskaya EV, Gray-Schopfer VC, Hill SP, Smit NP, Evans-Whipp $\mathrm{TJ}$, Bond J, et al. p16/cyclin-dependent kinase inhibitor $2 \mathrm{~A}$ deficiency in human melanocyte senescence, apoptosis, and immortalization: possible implications for melanoma progression. J Natl Cancer Inst. 2003:95(10): :723-32.

46. Herbig U, Jobling WA, Chen BP, Chen DJ, Sedivy JM. Telomere shortening triggers senescence of human cells through a pathway involving ATM, $p 53$, and $p 21$ (CIP1), but not $p 16$ (INK4a). Mol Cell. 2004;14(4):501-13

47. Freedman DA, Folkman J. CDK2 translational down-regulation during endothelial senescence. Exp Cell Res. 2005;307(1): 118-30. Epub 2005 Apr 21.

48. Egashira A, Kano K, Naito K. Preimplantation-embryo-specific cellcycle regulation is attributable to a low expression of retinoblastoma protein rather than its phosphorylation. J Reprod Dev. 2011;57(4): 492-9. Epub Apr 26.

49. Brown JP, Wei W, Sedivy JM. Bypass of senescence after disruption of 21 CIP1/WAF1 gene in normal diploid human fibroblasts. Science. 1997;277(5327):831-4.

50. Dumoulin JC, Land JA, Van Montfoort AP, Nelissen EC, Coonen E, Derhaag JG, et al. Effect of in vitro culture of human embryos on birthweight of newboms. Hum Reprod. 2010;25(3):605-12. Epub 2010 Jan 18.

51. Kallen B, Finnstrom O, Lindam A, Nilsson E, Nygren KG, Olausson PO. Blastocyst versus cleavage stage transfer in in vitro fertilization: differences in neonatal outcome? Fertil Steril. 2010;94(5):1680-3. Epub $2010 \mathrm{Feb} 4$.

52. Catt JW, Henman M. Toxic effects of oxygen on human embryo development. Hum Reprod. 2000;15 Suppl 2:199-206.

53. Orsi NM, Leese HJ. Protection against reactive oxygen species during mouse preimplantation embryo development: role of EDTA, oxygen tension, catalase, superoxide dismutase and pyruvate. Mo Reprod Dev. 2001;59(1):44-53

54. Meintjes M, Chantilis SJ, Douglas JD, Rodriguez AJ, Guerami AR, Bookout DM, et al. A controlled randomized trial evaluating the effect of lowered incubator oxygen tension on live births in a predominantly blastocyst transfer program. Hum Reprod. 2009;24(2) 300-7. Epub 2008 Oct 16.

55. Kovacic B, Sajko MC, Vlaisavljevic V. A prospective, randomized trial on the effect of atmospheric versus reduced oxygen concentration on the outcome of intracytoplasmic sperm injection cycles. Fertil tion on the outcome of intracytoplasmic sperm ing

56. Bontekoe S, Mantikou E, van Wely M, Seshadri S, Repping S, Mastenbroek S. Low oxygen concentrations for embryo culture in assisted reproductive technologies. Cochrane Database Syst Rev. 2012;7:CD008950.

57. Knijn HM, Gjorret JO, Vos PL, Hendriksen PJ, van der Weijden BC, Maddox-Hyttel P, et al. Consequences of in vivo development and subsequent culture on apoptosis, cell number, and blastocyst formation in bovine embryos. Biol Reprod. 2003;69(4):1371-8. Epub 2003 Jun 25. 


\subsection{Abstract: In-vitro culture stress due to ambient $\mathrm{O}_{2}$ induces a senescent-like phenotype with abundant DNA repair activity}

P.S92 Wedneoday, October 24, 2012

IN VITRO CULTURE STRESS DUE TO AMBIENT O2 ENDUCES A SENESCENT-LIKE PHENOTYPE WTH ABUNDANT DNA RE. PAIR ACTIVITY. L. Rogmanin, B. Wintechoff, I. Fradrickson,

OBJECTNE: Embryocuhure under armoepheric arygen contrikutes to in vitro cell stress via intracel halar ROS. Rabaced arygen conditions and addibon of pocken to the culare modia might ratace cell stress. Cel halar Senescence is defined by stable cell cycle arrest thx is triggezed by stress stimali. Sevenl biomarkers of senescence have been described and are correlated with cellal ar stress. The aim of this stady was to test if vrying in vilmo em. byo culhure condibions indoce differences in biomatkers for cellalar senescence.

DESKGN: Emprimental.

MATER LALS AND METHODS: Single-cell moase embryos were collocted from super ovalued FVB mice and alared in uitro to the blas-

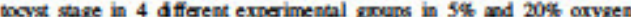

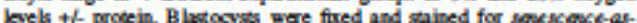

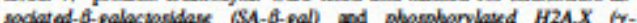

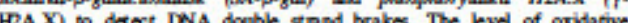

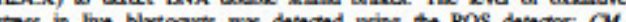
HODCFDA. RESULTS: SA-B-gal staining was positive in $51.1 \%$ of cells culhured

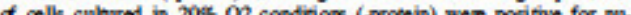

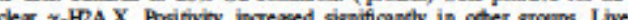
cllt 7 ined $X$ ith CM

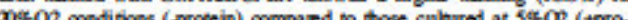
in) concentmoions.

CONCWSION: In vire culhre of embryos under atmospteric axygen levels correlixes wish a significant increase in biomurkes of cellalar senescence when compared to reduced arygen, saggerting increxed cellalar

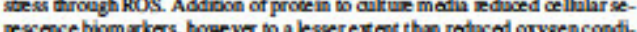

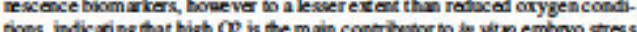

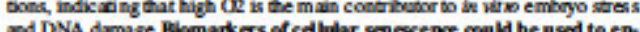
and DNA drmage Bsomankers of cd lubar senescence could be used to enhance aulture conditions for embryos.

Suppanted by: Mayo Clinic Depurtment of OB Gyn research grant.

FERTILITY \& STERILITY* 
10.3 Mayo Clinic Young Investigator Research Award

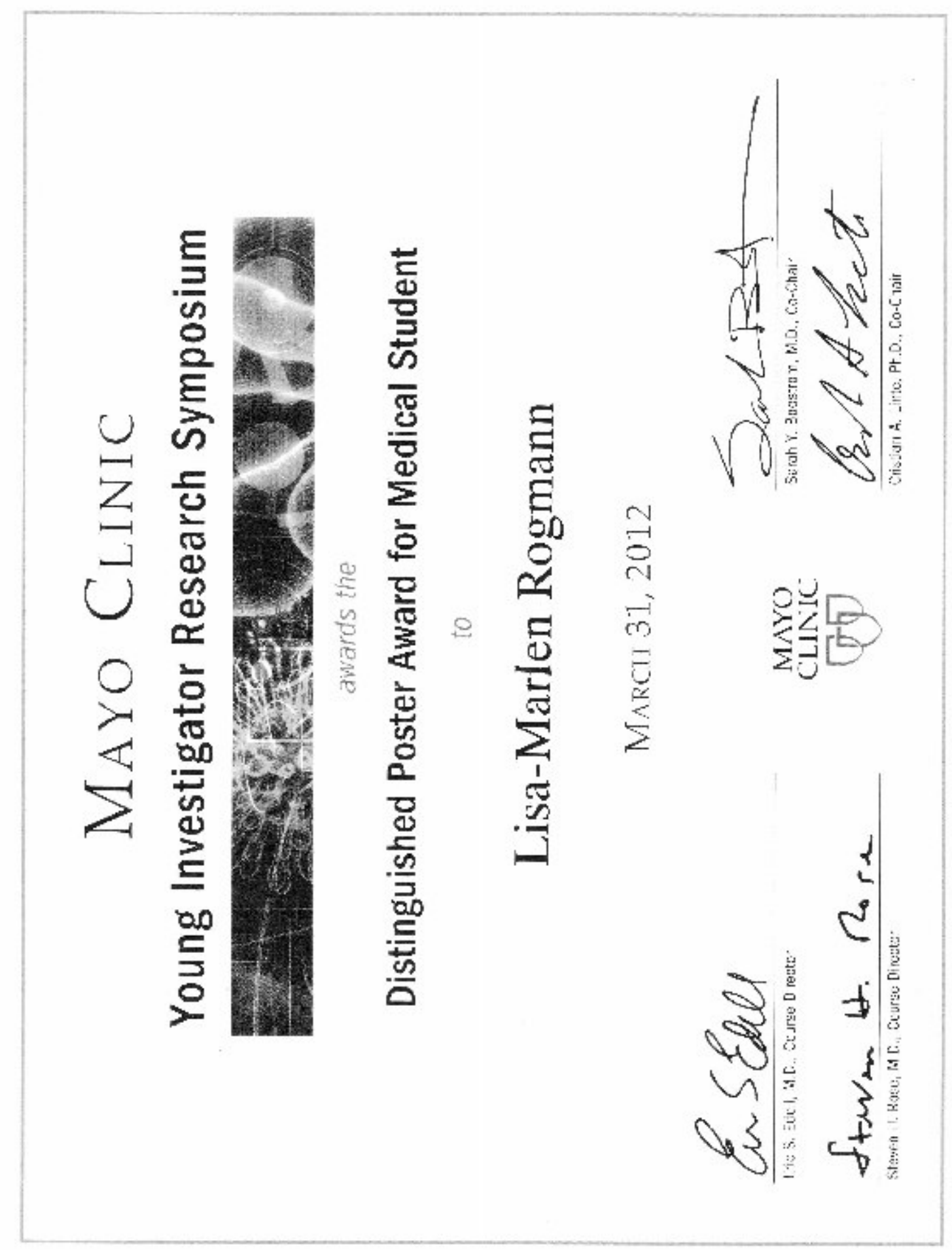




\section{Declaration of academic honesty}

Ich erkläre hiermit an Eides statt, dass ich die vorliegende Dissertation mit dem Thema:

In-vitro culture stress due to ambient $\mathrm{O}_{2}$ induces a senescent-like phenotype with abundant DNA repair activity

selbständig verfasst, mich außer der angegebenen keiner weiteren Hilfsmittel bedient und alle Erkenntnisse, die aus dem Schrifttum ganz oder annähernd übernommen sind, als solche kenntlich gemacht und nach ihrer Herkunft unter Bezeichnung der Fundstelle einzeln nachgewiesen habe.

Ich erkläre des Weiteren, dass die hier vorgelegte Dissertation nicht in gleicher oder in ähnlicher Form bei einer anderen Stelle zur Erlangung eines akademischen Grades eingereicht wurde.

Ort/ Datum:

Unterschrift:

Lisa-Marlen Rogmann 


\section{Acknowledgements}

This work was supported by the Robert and Arlene Kogod Center on Aging, the Noaber Foundation, the Glenn Foundation, NIH grant P01AG41122 (J.L.K.), and the Mayo Clinic Department of Obstetrics and Gynecology Research Committee (D.E.M.).

The funding sources had no role in study design; in the collection, analysis, and interpretation of data; in the writing of the report; and in the decision to submit the article for publication.

My cordial thanks to JL Kirkland, M.D., Ph.D. for the opportunity to work in his laboratory at the Mayo Clinic, Rochester (MN) and Prof. Dr. med. Ralf Schmidmaier, MME, for his extraordinary support at the Ludwig-MaximiliansUniversity in Munich.

I gratefully acknowledge Dean E. Morbeck, Ph.D. who guided and supported me throughout my project and inspired me scientifically during my stay in Rochester.

Special thanks to all my friends and colleagues, who made the time as a research student in Rochester an unforgettable experience.

My sincere and cordial thanks to Boris JN Winterhoff, MD for his support and for making my research stay in Rochester possible. It was a unique and imprinting experience.

Cordial thanks to Attila Teoman and Marlene Weiß as critical reviewers of my thesis.

My deepest gratitude and warmest feelings for my family and friends, who gave me their kind support and encouragement. 